ESTHER BORGES FLORSHEIM

\title{
MECANISMOS ENVOLVIDOS NA INDUÇÃO DA INFLAMAÇÃO ALÉRGICA PULMONAR PELA SERINO PROTEASE SUBTILISINA
}

Tese apresentada ao Programa de Pós-Graduação em Imunologia do Instituto de Ciências Biomédicas da Universidade de São Paulo, para obtenção do Título de Doutor em Ciências. 


\section{ESTHER BORGES FLORSHEIM}

\section{MECANISMOS ENVOLVIDOS NA INDUÇÃO DA INFLAMAÇÃO ALÉRGICA PULMONAR PELA SERINO PROTEASE SUBTILISINA}

Tese apresentada ao Programa de Pós-Graduação em Imunologia do Instituto de Ciências Biomédicas da Universidade de São Paulo, para obtenção do Título de Doutor em Ciências.

Área de concentração: Imunologia

Orientador: Prof. Dr. Momtchilo Russo

Versão original 
DADOS DE CATALOGAÇÃO NA PUBLICAÇÃO (CIP)

Serviço de Biblioteca e Informação Biomédica do

Instituto de Ciências Biomédicas da Universidade de São Paulo

reprodução não autorizada pelo autor

Florsheim, Esther Borges.

Mecanismos envolvidos na indução da inflamação alérgica pulmonar por serino protease subtilisina / Esther Borges Florsheim. -- São Paulo, 2014.

Orientador: Prof. Dr. Momtchilo Russo.

Tese (Doutorado) - Universidade de São Paulo. Instituto de Ciências Biomédicas. Programa de Pós-Graduação em Imunologia. Área de concentração: Imunologia. Linha de pesquisa: Imunobiologia.

Versão do título para o inglês: Mechanisms involved in the induction of allergic lung inflammation to the serine protease subtilisin.

$\begin{array}{llll}\text { 1. Subtilisina 2. Serino protease } & \text { 3. Asma ocupacional } & \text { 4. Inflamação }\end{array}$ pulmonar 5. Epitélio 6. Sensibilização alérgica I. Russo, Prof. Dr. Momtchilo II. Universidade de São Paulo. Instituto de Ciências

Biomédicas. Programa de Pós-Graduação em Imunologia III. Título. 
UNIVERSIDADE DE SÃO PAULO

INSTITUTO DE CIÊNCIAS BIOMÉDICAS

\author{
Candidato(a): $\quad$ Esther Borges Florsheim. \\ Título da Tese: $\quad$ Mecanismos envolvidos na indução da inflamação alérgica \\ pulmonar por serino protease subtilisina.
}

Orientador(a): $\quad$ Prof. Dr. Momtchilo Russo.

A Comissão Julgadora dos trabalhos de Defesa da Tese de Doutorado, em sessão pública realizada a ........... ...... considerou
( ) Aprovado(a)
( ) Reprovado(a)

\begin{tabular}{|c|c|}
\hline Examinador(a): & $\begin{array}{l}\text { Assinatura: } \\
\text { Nome: ........ } \\
\text { Instituição: }\end{array}$ \\
\hline Examinador(a): & $\begin{array}{l}\text { Assinatura: } \\
\text { Nome: ........ } \\
\text { Instituição: }\end{array}$ \\
\hline Examinador(a): & $\begin{array}{l}\text { Assinatura: } \\
\text { Nome: ........ } \\
\text { Instituição: }\end{array}$ \\
\hline Examinador(a): & $\begin{array}{l}\text { Assinatura: } \\
\text { Nome: ........ } \\
\text { Instituição: }\end{array}$ \\
\hline Presidente: & $\begin{array}{l}\text { Assinatura: } \\
\text { Nome: ........ } \\
\text { Instituição: }\end{array}$ \\
\hline
\end{tabular}




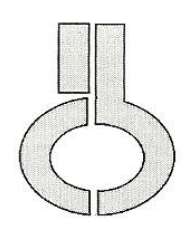

UNIVERSIDADE DE SÃO PAULO INSTITUTO DE CIÊNCIAS BIOMÉDICAS

Cidade Universitária "Armando de Salles Oliveira"

Av. Prof. Lineu Prestes, 2415 - CEP. 05508-000 São Paulo, SP - Brasil

Telefone :(55) (011) 3091.7733 - telefax : (55) (011) 3091.7438

e-mail: cep@icb.usp.br

\section{Certificado}

Certificamos que o protocolo registrado sob $n^{\circ} \mathbf{1 1 2}$ nas fls. 62 do livro 02 para uso de animais em experimentação, sob a responsabilidade de Momtchilo Russo, Coordenador(a) da Linha de pesquisa "Desenvolvimento de modelo experimental de asma ocupacional por protease" do qual participou(aram) o(s) alunos Esther Borges Florsheim, Paulo César Masini Augusto está de acordo com os Princípios Éticos de Experimentação Animal adotado pelo Colégio Brasileiro de Experimentação Animal (COBEA) e foi aprovado pela COMISSÃO DE ÉTICA EM EXPERIMENTAÇÃO ANIMAL (CEEA) em 28.11.08, com validade de 3 anos.

São Paulo, 02 de dezembro de 2008.
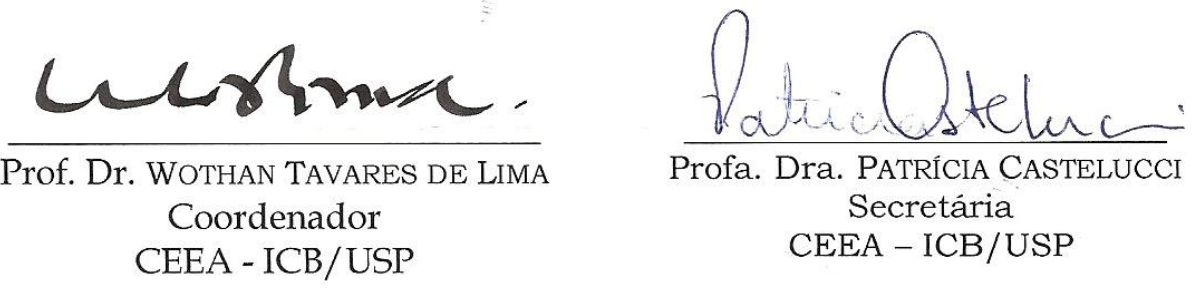


\section{UNIVERSIDADE DE SÃO PAULO}

INSTITUTO DE CIÊNCIAS BIOMÉDICAS

Cidade Universitária "Armando de Salles Oliveira"

Av. Prof. Lineu Prestes, 2415 - cep. 05508-000 São Paulo, SP - Brasil

Telefone :(55) (011) 3091.7733 - telefax : (55) (011) 30917438

e-mail: cep@icb.usp.br

\section{Of.CEUA.032.11}

São Paulo, 03 de outubro de 2011.

\section{REF.: Protocolo $\mathrm{n}^{0} \mathbf{1 1 2} / 08$.}

"Desenvolvimento de modelo experimental de asma ocupacional por protease"

Prezado Professor,

Informo que a sua licença para uso de animais em experimentação, constante no protocolo em epígrafe, estará em vigência até 28.11.2014.

Reitero que havendo alteração de metodologia e inserção de novos alunos ao projeto de pesquisa vinculado à referida licença a CEUAVICB deverá ser informada.

\section{Cordialmente,}

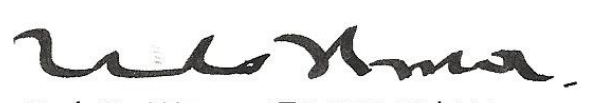

Prof. Dr. WOTHAN TAVARES DE LIMA

Coordenador da Comissão de Ética no Uso de Animal - ICB /USP

Ilmo. Sr.

Prof Dr. Momtchilo Russo

Departamento de Imunologia

Instituto de Ciências Biomédicas - USP 
Este trabalho foi desenvolvido no laboratório de Imunobiologia do departamento de Imunologia, do Instituto de Ciências Biomédicas, da Universidade de São Paulo, São PauloSP Brasil, e recebeu apoio financeiro da Fundação de Amparo à Pesquisa do Estado de São Paulo (FAPESP), processo 2008/57469-2, do Conselho Nacional de Desenvolvimento Científico e Tecnológico (CNPq) e Coordenação de Aperfeiçoamento de Pessoal de Nível Superior (CAPES).

Parte deste trabalho foi desenvolvido no laboratório de Imunologia do departamento de Imunobiologia da School of Medicine da Yale University, New Haven, CT EUA com auxílio financeiro da Fundação de Amparo à Pesquisa do Estado de São Paulo (FAPESP), processo 2012/07083-6, do National Intitutes of Health sob supervisão do Prof. Dr. Ruslan Medzhitov. 


\section{AGRADECIMENTOS}

Ao Prof. Dr. e amigo Momtchilo Russo, que me orienta desde a Iniciação Científica, sempre permitindo e incentivando a liberdade dos pesquisadores. Principalmente por se manter firme na posição que ocupa, mantendo uma ética impecável, e por ser meu maior exemplo de cientista e professor de excelência. "Iê, viva meu Mestre!"

Ao Prof. Dr. Ruslan Medzhitov, pela supervisão quando no seu laboratório na Yale University (New Haven, CT, EUA), pelo incentivo constante ao estudo e pelas profundas reflexões que contribuíram diretamente para esta tese bem como para minha formação científica.

À Dr. ${ }^{a}$ Luciana Mirotti, pelas atitudes generosas e companheirismo desde que entrou para o grupo de pesquisa do Prof. Dr. Momtchilo Russo. Também pelo exemplo de amizade, humor, atitude e ética na ciência e na vida. E pelas mil risadas.

À Eliane Gomes, pelo auxílio técnico desde que entrei no laboratório, pela disponibilidade em me ajudar sempre e pela amizade ao longo de todos estes anos.

A todos os colegas do Laboratório de Imunobiologia do ICB-USP (membros e exmembros), que contribuíram na manutenção de um ambiente de pesquisa sério e colaborativo e tanto me ajudaram, em especial: Bianca Balbino, Renato Barboza e Lucas Faustino, que acompanharam mais de perto minha trajetória e contribuíram de forma mais direta para esta tese.

A todos os colegas do Laboratório do Prof. Dr. Ruslan Medzhitov da Yale University (CT, EUA) que foram fundamentais para minha experiência nos EUA e influenciaram bastante minhas escolhas a partir desta vivência.

Ao Prof. Dr. Walter Terra, à Prof. ${ }^{a}$ Dr. ${ }^{a}$ Clélia Ferreira e ao Dr. Ivan Bragatto do Laboratório de Bioquímica de Insetos, do IQ-USP, pela colaboração, discussão e críticas fundamentais para este trabalho.

Ao Prof. Dr. José Alexandre Marzagão Barbuto e ao Rodrigo Nalio Ramos do Laboratório de Imunologia de Tumores, pela colaboração, amizade e discussões teóricas e práticas fundamentais para este trabalho.

À Dr. ${ }^{a}$ Maria Leite de Moraes pela supervisão quando no seu laboratório no Institute Necker-Enfants Malades (Paris, França) e pela experiência científica intensa.

Ao Prof. Dr. Anderson de Sá Nunes, à Prof. ${ }^{a}$ Dr. ${ }^{a}$ Eliana Faquim de Lima Mauro e à

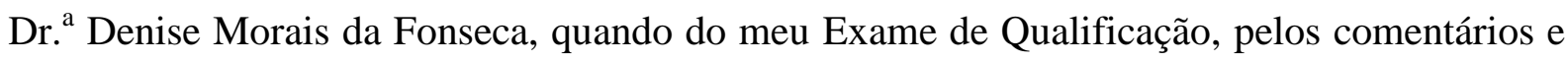
sugestões cruciais para a melhora da pesquisa e pela disponibilidade. 
À minha família: Henrique Borges Florsheim, David Borges Florsheim, Sandra Monteiro Borges Florsheim e Geraldo Henrique Moura Florsheim que me ajudaram com absolutamente tudo e em todos os momentos. É impossível nomear cada uma de suas contribuições.

Aos professores das instituições narradas nesta tese, ICB-USP e Yale University, pelas discussões formais e informais, em especial, à Prof. ${ }^{a}$ Dr. ${ }^{a}$ Ana Paula Lepique, à Prof. ${ }^{a}$ Dr. ${ }^{a}$ Sonia Jancar Negro e à Prof. ${ }^{\text {a }}$ Dr. ${ }^{a}$ Vera Lúcia Calich, por toda a atenção, paciência e por muito me ensinarem sobre a vida acadêmica.

Aos colegas, amigos e funcionários das instituições que acabo de mencionar, ICBUSP e Yale University, em especial, Alexandra Cassado, Matheus Ferracini, Marianna Mainardi Koga, Daniel Okin, Raj Chovatya e Tatiana Bondar, que me possibilitaram um percurso de pesquisa menos árduo. A vivência empírica foi indispensável para o pensamento teórico.

Ao Rodrigo Augusto Alves da Silva, pelas ilustrações deste trabalho e companheirismo.

À FAPESP, pelo auxílio-bolsa que muito me ajudou na pesquisa. 
A minha força foi não ter encontrado resposta para nada.

E. M. CIORAN

O ponto culminante da vida é a compreensão da vida.

G. SANTAYANA

Vivendo, se aprende; mas o que se aprende, mais, é só a fazer outras maiores perguntas.

JOÃO GUIMARÃES ROSA 


\section{RESUMO}

Florsheim EF. Mecanismos envolvidos na indução de inflamação alérgica pulmonar pela serino protease subtilisina. [tese (Doutorado em Imunologia)]. São Paulo: Instituto de Ciências Biomédicas, Universidade de São Paulo; 2014.

Proteases de diversas espécies representam uma das principais classes de alérgenos em humanos e a indução de resposta alérgica pulmonar parece estar associada à atividade enzimática presente em alguns aeroalérgenos. Contudo, os mecanismos envolvidos na geração deste tipo de inflamação por proteases ainda não foi totalmente elucidado. A primeira enzima associada a sintomas de alergia pulmonar foi a subtilisina, uma serino-protease derivada de espécies de Bacillus. Apesar das subtilisinas bacterianas terem sido responsáveis pela grande ocorrência de asma ocupacional em indústrias de detergente no final da década de 60 , nenhum modelo experimental de inflamação alérgica pulmonar foi estabelecido para esta protease. $\mathrm{O}$ objetivo deste projeto foi desenvolver um modelo murino de inflamação alérgica pulmonar induzida por subtilisina e elucidar os mecanismos imunológicos responsáveis por esta resposta. Verificamos que animais sensibilizados, por via subcutânea ou intranasal, e desafiados pela via intranasal com subtilisina desenvolveram inflamação pulmonar alérgica caracterizada por eosinofilia nas vias aéreas, liberação de citocinas tipo 2, produção de muco, altos níveis de IgE total sérica e alteração da reatividade pulmonar. Estas respostas foram dependentes da atividade enzimática da subtilisina e da expressão individual das moléculas PAR(protease-activated receptor)-2, MyD88, do receptor de IL-33, ST2, e do receptor de IL1, IL-1R, mas não foi dependente de TLR4. Ainda, a subtilisina induziu a expressão das citocinas pró-alérgicas IL-1 $\alpha$, TSLP, IL-33 e anfiregulina por células epiteliais brônquicas humanas de linhagem, mas não foi capaz de ativar diretamente células dendríticas humanas in vitro nem induzir a diferenciação de linfócitos Th2 a partir de co-cultura com estas células. Por fim, a administração intranasal de subtilisina induziu o aumento de células inatas linfóides tipo 2 no pulmão e promoveu a inflamação alérgica à OVA demonstrando sua capacidade adjuvante para um antígeno não correlacionado. Portanto, estabelecemos um modelo murino de asma ocupacional e caracterizamos as principais vias moleculares responsáveis pela sensibilização alérgica à subtilisina. Essas observações tem implicações em modelos de alergia por proteases e importância clínica, para a asma ocupacional, que continua como um grande problema de saúde pública ainda nos dias de hoje.

Palavras-chave: Subtilisina. Serino protease. Asma ocupacional. Sensibilização alérgica. PAR-2. ST2. IL-1R. MyD88. Epitélio. Inflamação pulmonar. 


\begin{abstract}
Florsheim EF. Mechanisms involved in the induction of allergic lung inflammation to serine protease subtilisin. [Ph.D. thesis (Immunology)]. São Paulo: Instituto de Ciências Biomédicas, Universidade de São Paulo; 2014.

Proteases represent a major class of allergens in humans, and the development of allergic lung inflammation seems to be associated with protease activity present in some airborne allergens. However, the mechanisms involved in the generation of allergic response to proteases are not fully understood. Subtilisin, a serine protease from Bacillus species, was the first enzyme linked to lung allergic symptoms. Even though subtilisin was the main responsible for occupational asthma outbreak in the detergent industry during the 60s, no experimental model of lung allergic inflammation to subtilisin was established. We sought to develop a murine model of occupational asthma induced by subtilisin and to determine the immunological mechanisms underlying lung allergic responses to this protease. We found that subcutaneous or intranasal sensitization followed by airway challenge with subtilisin induced allergic lung inflammation characterized by airway eosinophilia, type 2 cytokine release, mucus production and high levels of $\mathrm{IgE}$. These allergic responses were dependent on enzyme activity, proteaseactivated receptor (PAR)-2, IL-33 receptor ST2, IL-1 receptor IL-1R, and MyD88 signaling. Also, active subtilisin stimulated human bronchial epithelial cell line to express pro-allergic cytokines as IL-1 $\alpha$, TSLP, IL-33 and amphiregulin. However, subtilisin was not able to activate human dendritic cells or to induce Th2 differentiation in vitro. Finally, subtilisin increased lung type 2 innate lymphoid cells and acted as a Th2 adjuvant to an unrelated airborne antigen promoting allergic inflammation to inhaled OVA. Therefore, we established a murine model of occupational asthma to serine protease subtilisin and characterized the main molecular pathways involved in allergic sensitization. Our model proposes potential mechanisms by which proteases might trigger the immune system to initiate allergic airway disease.
\end{abstract}

Keywords: Allergic sensitization. Occupational asthma. Serine protease. Subtilisin. Proteaseactivated receptor (PAR)-2. MyD88. IL-33 receptor ST2. IL-1R. Epithelial cells. Lung inflammation. 


\section{LISTA DE ABREVIATURAS E SIGLAS}

AAF-AMC

AHR

alum

AR

Areg

AO

AUC

BAL

cAMP

CpG

DCs

Der p 1

DMSO

DNase

EC

ECM

ELISA

EtOH

E-64

FceRI

HRP

Id2

IFN- $\gamma$

IL-1R

Il1rl1

ILC2

i.n.

lin

LPS

LTi

MAPK

IBMMC
Ala-Ala-Phe 7-amido-4-methyl coumarin

Hiper-reatividade brônquica, airway hyper-reactivity

Gel de hidróxido de alumínio

Atividade remanescente

Anfiregulina, amphiregulin

Asma ocupacional

Área sob a curva, area under the curve

Lavado bronco alveolar, bronchoalveolar lavage

Cyclic adenosine monophosphate

Sequências de DNA ricas em CpG não metilado

Células dendríticas, dendritic cells

Alérgeno 1 de Dermatophagoides pteronyssinus

Dimetil sulfóxido, dimethyl sulfoxide

Desoxiribonuclease

Classificação enzimática, enzyme classification

Matriz extracelular, extracellular matrix

enzyme-linked immunosorbent assay

Etanol

Trans-epoxysuccinyl L-leucylamido(4-guanidine)butane

Receptor I da região Fc da imunoglobulina E

Horseradish peroxidase

Inibidor da ligação ao DNA 2, inhibitor of DNA binding 2

Gamma interferon

Receptor da interleucina 1- Interleukine 1 receptor

Receptor 1 símile ao receptor de IL-1, IL-1 receptor like-1

Células linfóides inatas tipo 2 - Innate lymphoid cells type 2

Intranasal

Marcadores de linhagens celulares

Lipopolissacarídeo

Indutor de tecido linfóide, lymphoid tissue-inducer

Mitogen-activated protein kinase

Mastócitos murinos derivados de medula óssea, murine bone marrow-

derived mast cells 
MCh

MFI

MHC II

MM

MyD88

NFAT

NF-kB

NK

OVA

PAR-2

PAS

PBS

Penh

PMA

PMSF

qPCR

s.c.

SFB

STAT

TNF- $\alpha$

TLR

TSLP

Z-R-AMC

$\alpha$ GalCer
Metacolina, metacholine

Intensidade de fluorescência média, mean fluorescence intensity

Moléculas codificadas pelo complexo principal de histocompatibilidade da classe II, major histocompatibility complex class II

Massa molecular

Fator de diferenciação mielóide 88, myeloid differentiation primary response 88

Nuclear factor of activated $T$ cells

Fator nuclear - kappa B, nuclear factor-kappa $B$

Células natural killer

Ovoalbumina, ovalbumin

Receptor ativado por protease 2, protease-activated receptor 2

Periodic acid-Schiff

Salina tamponada de fosfato, phosphate buffered saline

Aumento da pausa respiratória, enhanced pause

Phorbol 12-myristate 13-acetate

Phenylmethylsulfonyl fluoride

Reação em cadeia da polimerase quantitativa em tempo real, real-time quantitative polymerase chain reaction

Subcutâneo

Soro fetal bovino

Signal transducer and activator of transcription

Fator alpha de necrose tumoral, tumor necrosis factor $\alpha$

Receptor símile ao Toll, Toll-like receptor

Linfopoietina estromal tímica, thymic stromal lymphopoietin

Carbobenzoxi-arginin-7-amido-4-methylcoumarin

$\alpha$-galactosilceramida 


\section{LISTA DE ILUSTRAÇÕES}

Figura 1- Causas e consequências fisiológicas e patológicas da inflamação. .22

Figura 2- Diversos estímulos ativam a imunidade tipo II. 25

Figura 3- Inflamação alérgica das vias aéreas induzida por subtilisina ou papaína.

Figura 4- Efeito da subtilisina na função respiratória. .56

Figura 5- Inibição das atividades enzimáticas da subtilisina e papaína por alum ou modificadores específicos. .58

Figura 6- A atividade de serino-protease da subtilisina é essencial para o desenvolvimento da resposta alérgica......

Figura 7- Perfil de citocinas e fatores de transcrição em linfócitos $\mathrm{T}$ pulmonares

Figura 8- A resposta alérgica induzida pela subtilisina é dependente de MyD88, mas não de TLR4.

Figura 9- A resposta alérgica induzida por subtilisina é dependente do receptor de IL1. 68

Figura 10- A resposta alérgica induzida pela subtilisina é dependente da expressão do PAR-2 .70

Figura 11- A subtilisina não promove ativação de DCs humanas nem polarização de linfócitos T diretamente. . .72

Figura 12- A subtilisina induz citocinas pró-alérgicas e proteína de reparo em células epiteliais.

Figura 13- Caracterização de células linfóides inatas tipo 2 (ILC2) pulmonares após administração intranasal de IL-25r ou subtilisina. .80

Figura 14- Administração intranasal de subtilisina promove respostas tipo 2 dependente de PAR-2. 
Figura 15- A inflamação alérgica induzida por subtilisina nas vias aéreas é dependente do receptor de IL-33, ST2, e de MyD88.

Figura 16- A subtilisina exerce atividade adjuvante à OVA.........................................86

Figura 17- Início e desenvolvimento de respostas tipo II promovidas pela subtilisina: proposta de modelo. .98 


\section{SUMÁRIO}

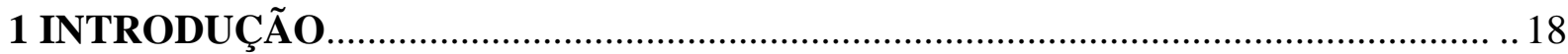

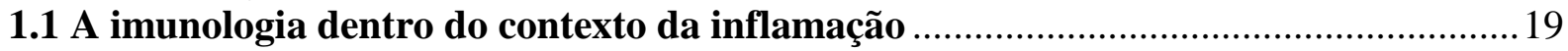

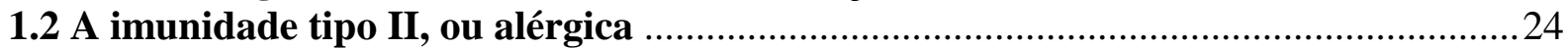

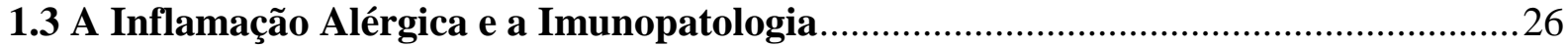

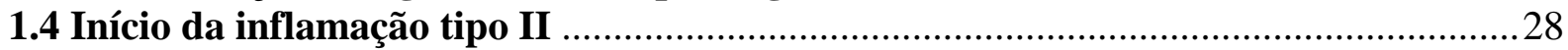

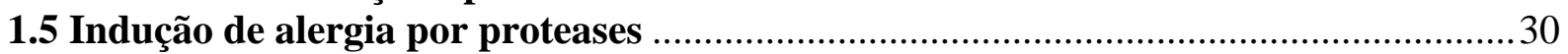

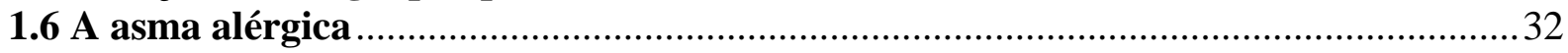

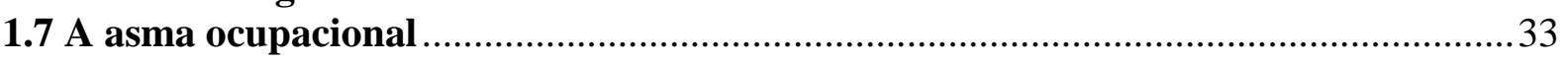

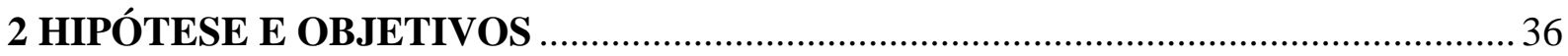

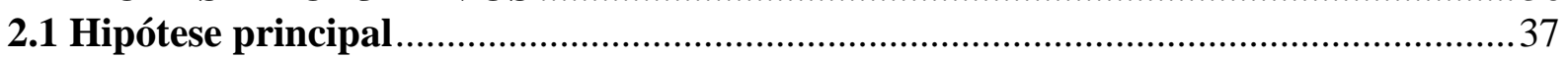

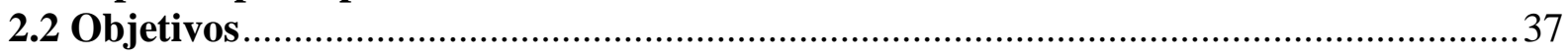

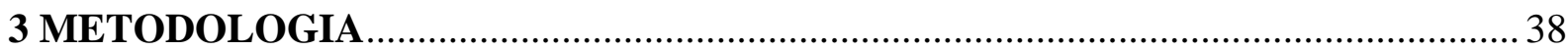

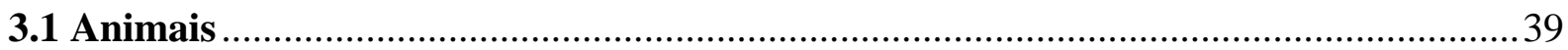

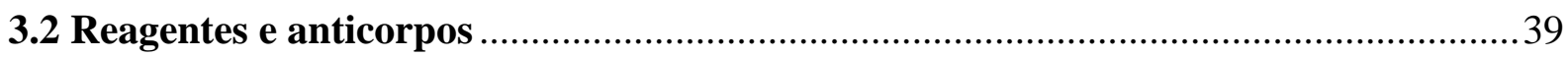

3.3 Determinação da concentração e integridade das proteases .................................... 40

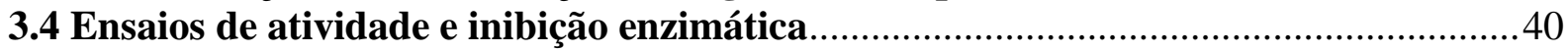

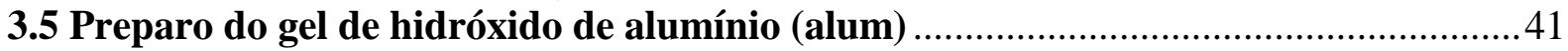

3.6 Protocolos experimentais de inflamação alérgica das vias aéreas ..............................41

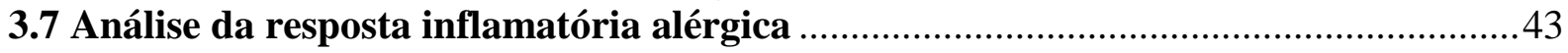

3.8 Caracterização fenotípica de populações celulares ............................................. 44

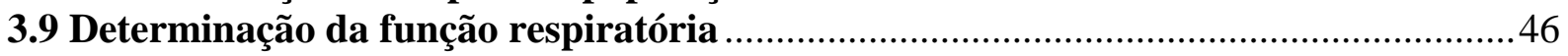

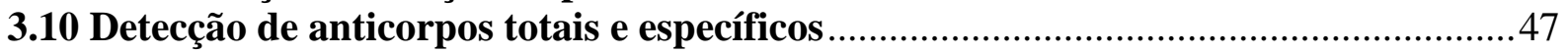

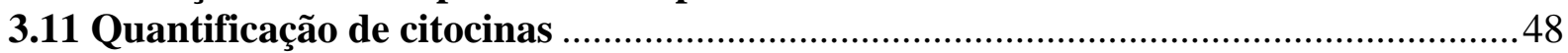

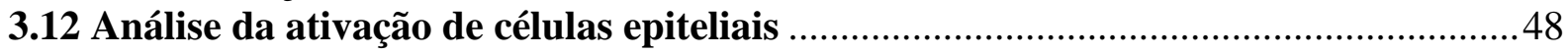

3.13 Diferenciação de células dendríticas humanas (hDCs) e polarização de linfócitos $\mathbf{T}$

3.13.1 Participantes do Estudo............................................................49

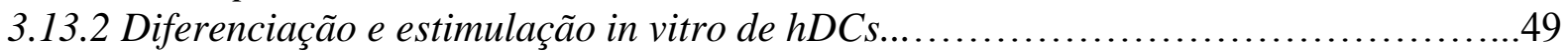

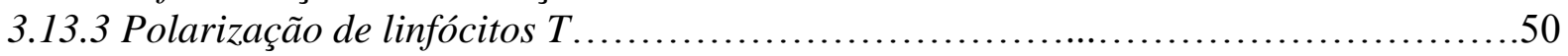

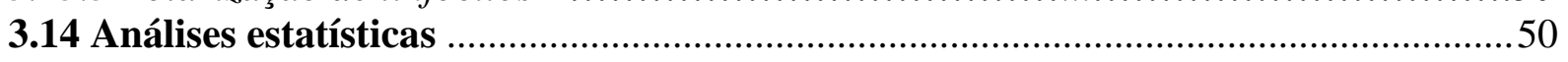

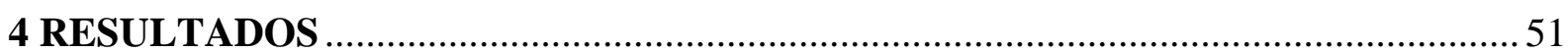

4.1 Modelo experimental de alergia pulmonar induzida por subtilisina ...........................52

4.2 A atividade enzimática da subtilisina é fundamental no desenvolvimento da

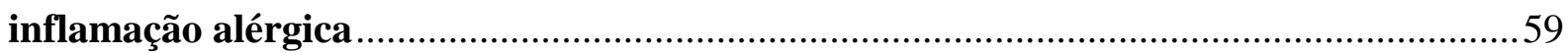

4.3 A resposta alérgica à subtilisina é dependente da molécula adaptadora MyD88, do

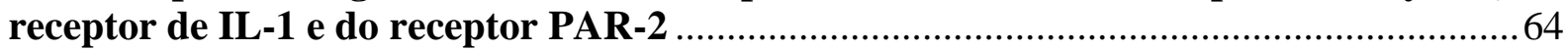

4.4 Efeito da subtilisina em populações de células imunes inatas ...................................71

4.4.1 Ação da subtilisina em células dendríticas e diferenciação de linfócitos Th2 ...........71

4.4.2 Ação da subtilisina em outras células do sistema imune .................................73

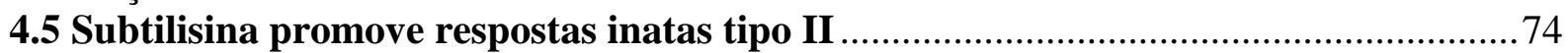

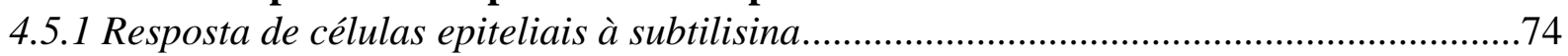

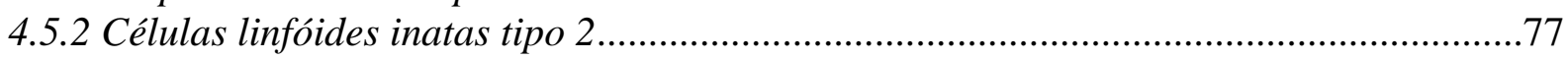

4.6 A inflamação tipo 2 induzida por subtilisina intranasal é dependente do PAR-2, do

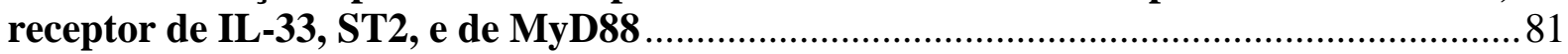

4.7 Subtilisina intranasal promove sensibilização alérgica à OVA ................................. 85

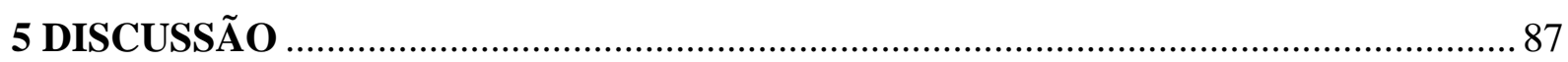


6 CONSIDERAÇÕES FINAIS

.96

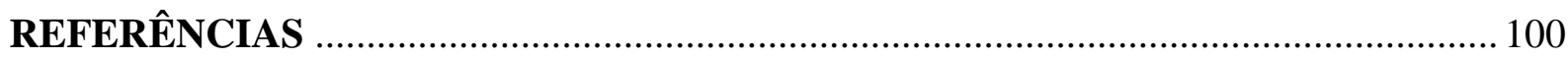

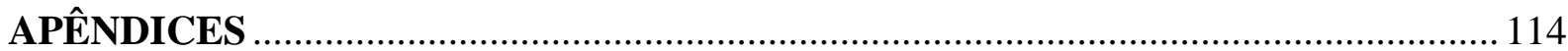

APÊNDICE A - Artigos publicados ou submetidos durante o período do doutorado ...........115 APÊNDICE B - Artigo publicado na SBI na rede: "O Hajj da imunologia atual: imunidade Th2" 
1 INTRODUÇÃO 


\subsection{A imunologia dentro do contexto da inflamação}

Em 1794, o cirurgião escocês John Hunter escreveu que "a inflamação, em si, não é para ser considerada como uma doença, mas como um processo resultante de alguma injúria ou doença” (MAJNO, 1991). Esta ideia implica que a resposta inflamatória representa um fenômeno bem sucedido de resolução e reparo tecidual, em vez de um processo persistente que necessariamente resulta em perda de função orgânica e desequilíbrio da homeostasia interna (SERHAN; SAVILL, 2005).

A inflamação é conhecida pela humanidade há, pelo menos, alguns milhares de anos em parte porque é bastante evidente e muitas vezes acompanhada de moléstias e infecções. Apesar de referências à resposta inflamatória serem encontradas em textos médicos da antiguidade, aparentemente, o médico romano Aulus Cornelius Celsus foi o primeiro a definir os sintomas clínicos deste processo, no século primeiro. Estes sintomas vieram a ser conhecidos como os quatro sinais cardinais da inflamação: rubor et tumor cum calore et dolore (vermelhidão e inchaço com calor e dor). As bases fisiológicas dos sinais cardinais da inflamação vieram bem mais tarde com Augustus Waller (1846) e Julius Cohnheim (1867), que descobriram a vasodilatação, extravasamento de plasma e migração de leucócitos dos vasos sanguíneos em direção ao tecido. O quinto sinal cardinal da inflamação, functio laesa (alteração de função), foi adicionado por Rudolph Virchow em 1858 em seu livro Cellularpathologie (MAJNO, 1991).

O dicionário português online define inflamação, do latim inflammatio (atear fogo), como uma

reação patológica que se estabelece em seguida a uma agressão traumática, química ou microbiana do organismo, e que se caracteriza pelo calor, rubor, dor e tumefação. É o processo pelo qual o corpo procura livrar-se de bactérias, venenos ou outras substâncias estranhas que irritam ou lesam os tecidos. ("Dicionário Online de Português," [s.d.]). Maio de 2014.

Esta definição representa a visão mais tradicional e clássica do processo inflamatório (ZWEIFACH, 1974), que muito contribuiu para desvendar os principais mecanismos de ação responsáveis pelo fenômeno em questão. No entanto, ela não é a única interpretação possível e pode ser considerada incompleta e ultrapassada (MEDZHITOV, 2010). Em primeiro lugar, porque se refere apenas às reações inflamatórias agudas em resposta à injúria e infecções. 
Sabemos agora que a inflamação pode se apresentar de diversas formas e ser controlada por diferentes mecanismos de indução, regulação e resolução. Nas últimas duas décadas, tem se dado maior atenção aos estados inflamatórios crônicos que acompanham, por exemplo, a asma, aterosclerose, diabetes tipo 2, doenças neurodegenerativas e câncer e, para as quais, esta classificação não se aplica. Em segundo lugar, esta visão considera, por razões sociais e históricas (SILVERSTEIN, 2003), que a inflamação é uma reação patogênica. Como tentarei explicar a seguir, esta também não é uma interpretação compartilhada por todos os especialistas nesta área. Terceiro, a ideia de que nosso corpo precisa se livrar de bactérias é, além de finalista, equivocada, principalmente, à luz de estudos recentes sobre organismos comensais, como a microbiota intestinal, por exemplo. Ainda, o conceito de "substâncias estranhas" e a distinção de próprio e não-próprio são noções bastantes controversas desde sempre na Imunologia e possuem diferentes implicações dependendo de sua utilização (TAUBER, 2003). Essas críticas à visão tradicional da inflamação, partindo da definição dada pelo dicionário, foram colocadas como um exemplo da complexidade que o conceito deste fenômeno biológico pode representar, com implicações práticas importantes.

Disse anteriormente, na segunda crítica à definição de inflamação, que outras abordagens acerca deste fenômeno não o consideram como uma reação patogênica. Ao contrário, a inflamação é interpretada por alguns como um fenômeno da fisiologia do organismo. O melhor exemplo desta linha de pensamento pode ser encontrado nos trabalhos de Elie Metchnikoff, que descobriu a fagocitose e desenvolveu a teoria da imunidade celular por volta de 1892 (TAUBER; CHERNYAK, 1991). Metchnikoff enfatizou os aspectos benéficos da inflamação e apontou a participação fundamental dos macrófagos e neutrófilos (micrófagos) na manutenção da homeostase tecidual. Para ele, a resposta inflamatória é um conjunto de atividades celulares que visa o reestabelecimento da "harmonia" do organismo e denominou este processo inflamação fisiológica (TAUBER, 2003). Em outro exemplo, Ramos define inflamação como um aspecto do desenvolvimento e da atividade normal do organismo animal (RAMOS, 2011). VAZ (2006) já havia discutido anteriormente a inflamação fisiológica como um processo biológico de construção e conservação que considera a história ontogenética dos organismos. Essas abordagens se contrapõem às ideias da Patologia, que define a inflamação como uma resposta a agentes patogênicos, e às da Imunologia, que vê este fenômeno como uma reação de defesa do organismo.

Podemos complicar ainda mais esse cenário ao nos questionar se organismos de outros Reinos, não-animais, podem apresentar atividade inflamatória. Por exemplo, no caso de plantas sabe-se que há uma resposta ativa a sinais patogênicos, tipo vírus, bactérias ou fungos. 
Há diversos processos análogos ao que acontece em animais na reação a distúrbios teciduais em plantas, como a indução de morte celular, peptídeos anti-microbianos, silenciamento de RNA, produção de espécies reativas de oxigênio e de hormônios de crescimento para reparo de lesão (DELAUNOIS et al., 2014; JONES; DANGL, 2006). Até o modo de reconhecimento desses sinais é, muitas vezes, similar ao utilizado em animais, ou seja, pelo reconhecimento de padrões moleculares por receptores transmembrânicos (ZIPFEL; FELIX, 2005). Decerto, estas resposta não são homólogas às que ocorrem em animais, mas dependendo da definição utilizada para inflamação elas poderiam ser consideradas como fenômenos análogos.

Pelo exposto até aqui percebe-se que não há apenas uma forma de entender a inflamação, nem tampouco há uma resposta final a esta questão de definir este fenômeno. As tentativas de entender os mecanismos e principais mediadores responsáveis pela reação inflamatória, em vez de formar de um conceito global do fenômeno inflamatório resultaram na fragmentação deste conceito. Diante dessa contradição, o patologista Ernst Ziegler comentou, em 1889: “À medida que o fenômeno não é único, uma definição breve e precisa da inflamação é completamente impossível” (ZIEGLER, 1889), tradução nossa. Ludwig Aschoff, um dos mais influentes patologistas do início do século $\mathrm{XX}$, também sugeriu abandonar essa noção geral da inflamação e, em vez disto, considerar os "estados de reatividade" de uma atividade inflamatória dentro de cada contexto específico (apud PARNES, 2003).

Ainda assim, me parece importante a exposição e discussão destas ideias, pois diferentes interpretações de um assunto levam a abordagens de estudo também distintas (KUHN, 2005). A partir disto, utilizo a ideia proposta por Metchnikoff e adaptada por MEDZHITOV (2008b) e tento definir a inflamação como uma atividade protetora restrita ao Reino Metazoa à injúria e estresse teciduais que ocorre inevitavelmente ao custo da função tecidual normal. Dessa maneira, esse fenômeno potencialmente patológico tem por objetivo a restauração da integridade e adaptação do tecido afetado. A inflamação não pode ser reduzida a respostas celulares individuais e independentes. É, ao contrário, uma reação integrada e complexa e dela participam diferentes componentes celulares e moleculares que vamos estabelecer a seguir, no contexto mais específico deste trabalho, que trata da inflamação do tipo alérgica. A figura 1, adaptada de uma revisão recente, representa um esquema desta abordagem mais fisiológica da inflamação em termos dos agentes indutores, propósitos e consequências dessas atividades (MEDZHITOV, 2008b). 
Figura 1- Causas e consequências fisiológicas e patológicas da inflamação.

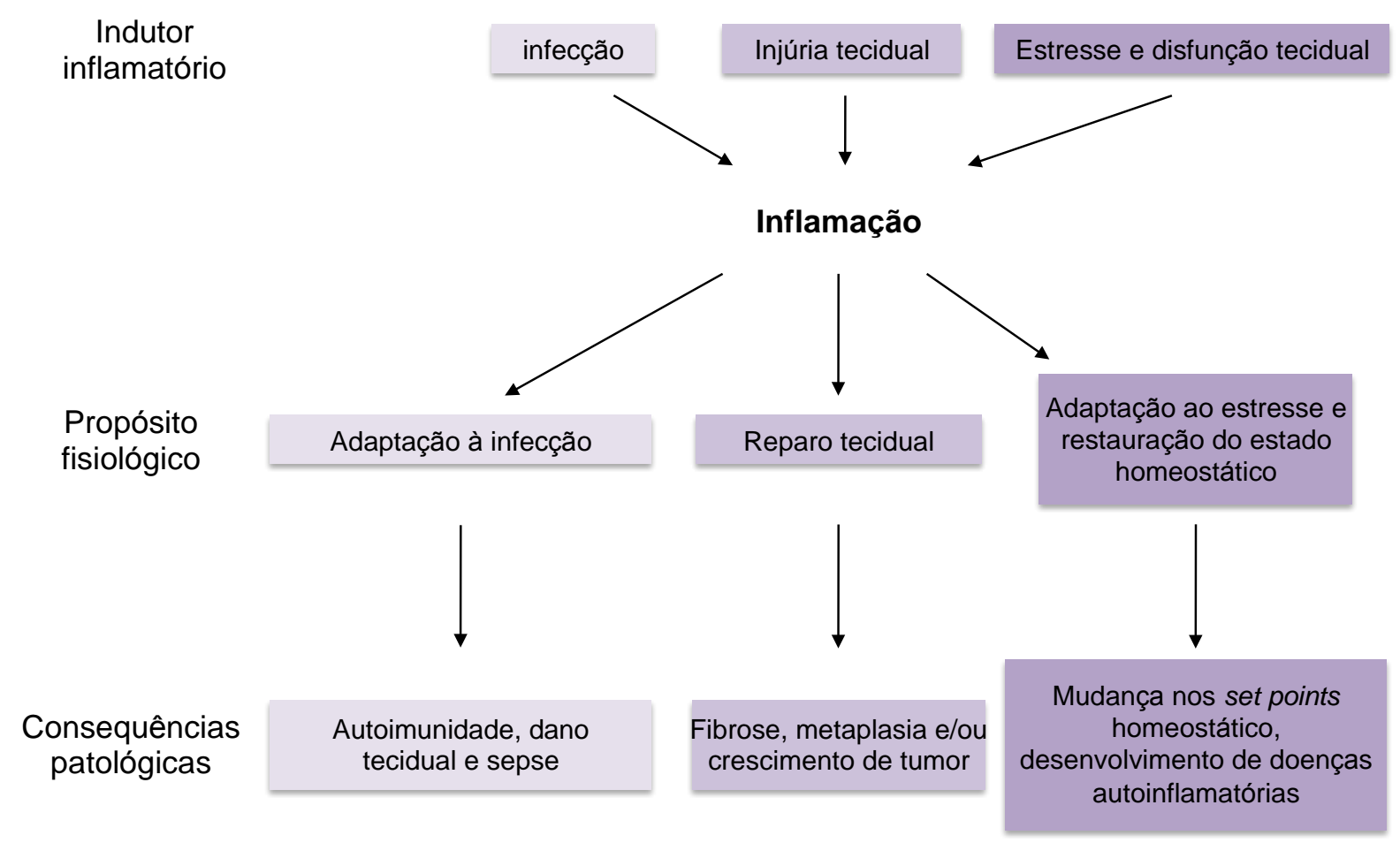

A inflamação engloba tanto processos fisiológicos como patológicos e, dependendo do agente indutor, a resposta inflamatória pode apresentar diferentes propósitos fisiológicos e consequências patológicas. Tradicionalmente, a inflamação é causada por infecção e dano tecidual, os quais promovem uma resposta imunológica acoplada e processos de reparo. No entanto, a desregulação homeostática de diversos sistemas fisiológicos também pode levar à atividades inflamatórias, em geral, crônicas. Modificado do artigo de revisão "Origin and physiological roles of inflammation", (MEDZHITOV, 2008a).

A separação entre o estudo da imunologia e o da inflamação se deu a partir da segunda metade do século XX e persiste até hoje, com "graves consequências sobre o entendimento da patologia da atividade imunológica e sobre a ausência de uma fisiologia imunológica" (VAZ, 2011). Por este motivo é que resolvemos contextualizar nosso trabalho, em Imunologia, no âmbito maior da Inflamação.

A imunologia nasceu do estudo de doenças infecciosas e desde sua origem, no final do século XIX, existe a ideia de que a doença representa uma forma de luta entre espécies de seres vivos, entre as células do hospedeiro e as do patógeno (VAZ et al., 2011). Dessa forma, criou-se rapidamente o conceito de defesa imunológica como a principal função do sistema imunológico (SILVERSTEIN, 2005). Apesar de abundantes evidências contra esta 
interpretação, como a tolerância imunológica, interação com a microbiota, reações autoimunes e alergias, a noção de defesa ainda se caracteriza como o paradigma vigente na Imunologia contemporânea.

Seguindo as ideias de Vaz e Varela, o sistema imunológico não possui tal finalidade, a de defesa do organismo. É, ao contrário, uma atividade sem intencionalidade ou direcionamento, que atua para conservação da fisiologia do organismo como um todo e cuja atividade não depende somente do ambiente externo (VAZ; VARELA, 1970).

O sistema imunológico é tradicionalmente dividido em mecanismos inatos e adaptativos, cada um com funções distintas. Basicamente, esta categorização surgiu pela observação de que a vasta maioria dos animais, os invertebrados, não possuem linfócitos, que é o tipo celular responsável pela imunidade adaptativa, ou adquirida, caracterizada pela memória imunológica específica. O conceito da imunidade inata, por sua vez, foi criado para abranger uma variedade de processos heterogêneos que participam da resposta de "defesa" em animais sem linfócitos, muitos dos quais estão também presentes nos vertebrados. Uma boa discussão sobre a inadequação do termo “inato” pode ser encontrada em VAZ (2011).

De qualquer forma e por falta de termo melhor, aceita-se que é a imunidade "inata" que inicia e direciona a resposta imunológica adquirida, pelo reconhecimento de padrões moleculares estereotipados, controlando a ativação, diferenciação e proliferação dos linfócitos. Esta teoria, proposta por Charles Janeway em 1989, modificou radicalmente a pesquisa em Imunologia e estimulou a descoberta de diversas moléculas e receptores da imunidade inata (JANEWAY, 1989).

Por causa dessa abordagem das atividades imunológicas no contexto de defesa do organismo, o principal interesse dos imunologistas foi, até recentemente, descobrir os mecanismos responsáveis pelo reconhecimento de patógenos e dos processos que atuam no "combate" aos agentes invasores e infecciosos. Apesar de grandes avanços nessa área, percebe-se que esta é apenas uma das propriedades desse sistema e representa, provavelmente, uma exceção dentre todas as atividades imunológicas presentes no organismo. Portanto, parece-nos mais interessante explorar as propriedades desse sistema sob outro prisma, diferente da "defesa" e da interação apenas com microorganismos patogênicos, que posicione os processos imunológicos à fisiologia normal do organismo. Uma perspectiva semelhante foi proposta por Gérard Eberl (EBERL, 2010b). Neste intuito, começamos por analisar as inflamações alérgicas, ou tipo II, assunto principal deste trabalho, por esta perspectiva fisiológica, menos antropocêntrica. 


\subsection{A imunidade tipo II, ou alérgica}

Uma das atividades do sistema imunológico menos apreciadas pelos pesquisadores, pelos motivos mencionados na seção anterior, é a resposta do tipo II, ou alérgica. Com a clássica distinção entre respostas tipo I e tipo II, originalmente Th1 e Th2, proposta por Mosmann e Coffman há quase 30 anos (MOSMANN et al., 1986), muitos dos trabalhos subsequentes se focaram em desvendar os mecanismos responsáveis pela imunidade tipo 1 , já que é a tipicamente associada à patogênese de diversas infecções, tendo o IFN- $\gamma$ como principal molécula efetora. No entanto, os mecanismos que levam à fase inicial das reações alérgicas e respostas à infecção por helmintos, nomeadas tipo II, continuam misteriosos.

De maneira geral e simples, a fase efetora das respostas imunológicas tipo II é mediada por linfócitos $\mathrm{T}_{\mathrm{CD}} 4^{+} \mathrm{Th} 2$ e anticorpos $\mathrm{IgE}$ e IgG1, assim como diversos componentes do sistema imune inato, incluindo as barreiras epiteliais, células linfóides inatas (ILCs, innate lymphoid cells), eosinófilos, mastócitos, basófilos e macrófagos ativados pela via alternativa (LICONA-LIMÓN et al., 2013). Voltaremos a dar detalhes dos componentes e mecanismos envolvidos nas respostas alérgicas na próxima seção. Este tipo de imunidade participa na reação a macroparasitas (helmintos e ectoparasitas, como carrapatos) e também pode ser gerada em resposta a uma ampla diversidade de estímulos ambientais não infecciosos, denominados alérgenos. A figura 2, adaptada de Palm et cols. representa os diversos estímulos capazes de ativar a imunidade tipo II assim como as consequências dessa atividade no organismo (PALM; ROSENSTEIN; MEDZHITOV, 2012). 


\section{Figura 2- Diversos estímulos ativam a imunidade tipo II.}

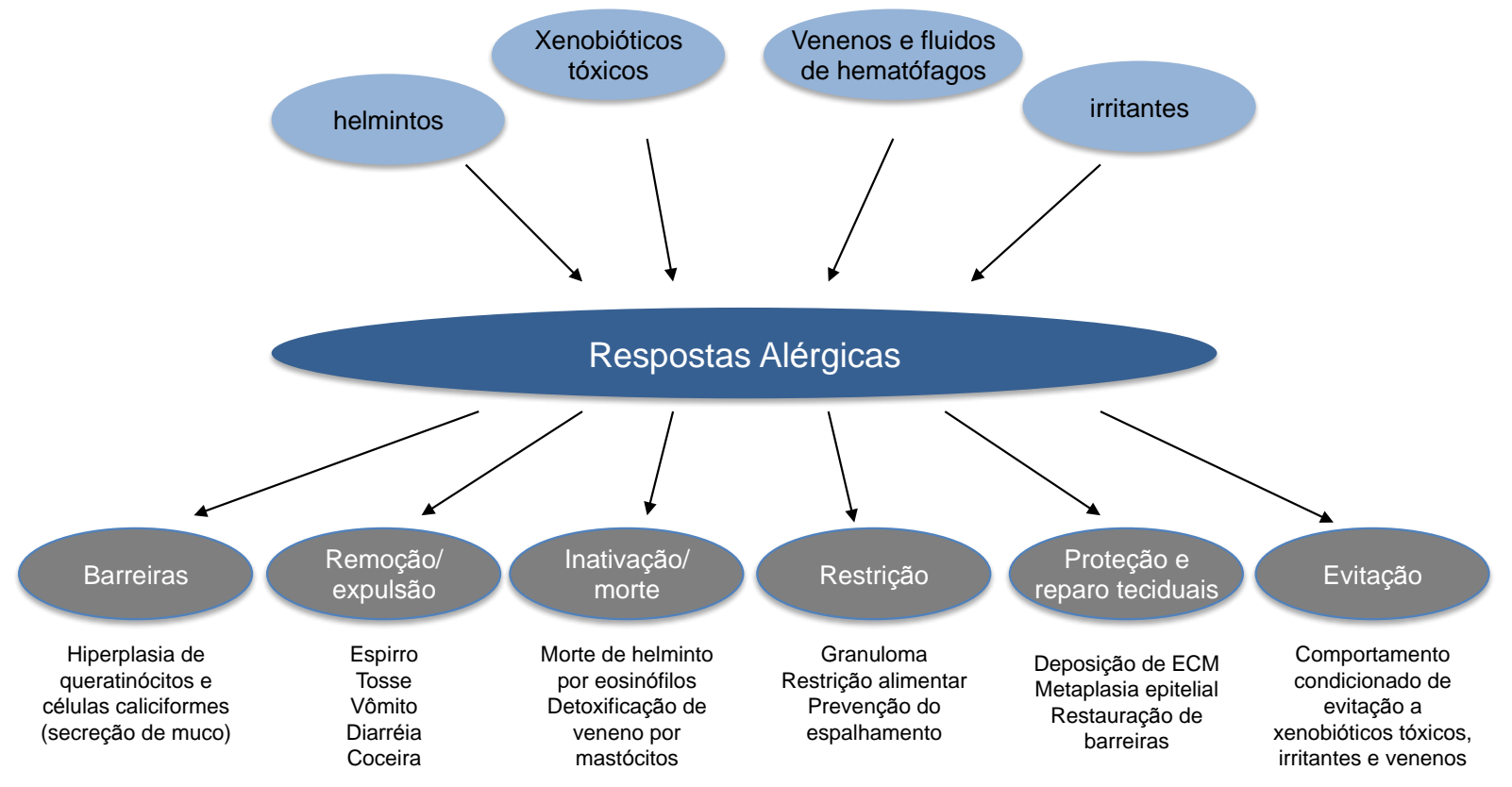

Quatro classes diferentes de estímulos podem ativar a imunidade tipo II, chamada pelos autores de "defesas alérgicas do hospedeiro" (allergic host defences): helmintos, xenobióticos tóxicos (como urushiol da hera venenosa), venenos (por exemplo de abelhas Apis meliffera) e irritantes (partículas de diesel, por exemplo). A resposta a estes estímulos é constituída de vários módulos (mostrados na figura em cinza). A hiperplasia de queratinócitos e células caliciformes (secreção de muco) estimula funções de barreira para reduzir a exposição aos alérgenos e restringir a entrada e crescimento de helmintos. Espirro, tosse vômito, diarréia e coceira servem para remover ou expelir substâncias nocivas. Os eosinófilos podem matar helmintos, enquanto a heparina e as proteases dos mastócitos podem inativar venenos por neutralização e desintoxicação. A formação de granuloma e macrófagos ativados pela via alternativa podem restringir helmintos. O granuloma também limita o dano causado por irritantes. Fibroblastos e macrófagos ativados alternativamente (AAMs) coordenam o reparo tecidual por metaplasia epitelial, deposição de matrix extracelular (ECM) e restauração das barreiras. Diversas reações alérgicas também podem levar a respostas comportamentais condicionadas, para evitar futuro contato com a substância irritante. Retirado e modificado do artigo "Allergic host defences", (PALM; ROSENSTEIN; MEDZHITOV, 2012b).

O paradigma vigente estabelece que as respostas imunológicas mediadas por linfócitos Th2 e IgE evoluíram para proteger os vertebrados contra parasitas multicelulares, mas que essas atividades também podem levar à alergia quando ativadas acidentalmente por antígenos ambientais não infecciosos (GALLI; TSAI; PILIPONSKY, 2008). Os problemas com esta interpretação foram melhor citados por Palm e cols. e este grupo retoma a explicação de que a proteção contra macroparasitas é apenas uma das várias atividades, sendo a função principal 
das respostas alérgicas a de proteger contra toxinas ambientais (PROFET, 1991). Outra interpretação foi proposta este ano e considera a imunidade tipo II como uma atividade fisiológica essencialmente de reparo tecidual (ALLEN; SUTHERLAND, 2014).

Como mencionado anteriormente, a atenção de grande parte dos imunologistas estava em estudar a inflamação tipo I e descobrir as propriedades do sistema imunológico no contexto das infecções. Fora isto, outras razões foram, a nosso ver, fundamentais para que os mecanismos da inflamação tipo II permanecessem desconhecidos por tanto tempo, que são: 1) definir um grupo de substâncias comuns indutoras de alergias, 2) o reconhecimento de alérgenos e fase inicial da inflamação tipo II parecem ocorrer de maneira diferente da resposta tipo I, 3) falta de consenso entre pesquisadores (foi proposto mais de um mecanismo principal, não correlacionados) e, por fim, 4) nunca houve um modelo in vitro de recapitulação da resposta Th2. Por esses motivos, essa área da imunologia recebeu pouca atenção e pouco progresso foi observado em relação às outras. Isto faz com que ela seja única dentro da Imunologia e demanda uma atenção maior.

\subsection{A inflamação alérgica e a imunopatologia}

"A noção de que anticorpos, que deveriam proteger contra doenças, são também responsáveis pela doença parece, a princípio, absurda." (Clemens von Pirquet, 1906, tradução nossa).

O termo 'alergia' (grego: allos, ergos, reatividade alterada) foi cunhado por Clemens von Pirquet em 1906 para chamar atenção à propensão incomum de alguns indivíduos de desenvolver sinais e sintomas de reatividade, ou 'reações de hipersensibilidade', quando expostos a certas substâncias (RING, 2014; SILVERSTEIN, 2009). Apesar da citação acima se referir à doença do soro, as disordens alérgicas (também conhecidas como disordens atópicas, do grego atopos, fora de lugar) também estão associadas à produção de IgE específica ao alérgeno e à expansão de linfócitos T específicos, ambos os quais são reativos a substâncias ambientais tipicamente inócuas. É interessante notar que, ao contrário de outras imunopatologias, as disordens alérgicas só afetam tecidos em que há uma interface com o ambiente externo, como a pele e mucosas. Umas das consequências mais graves das respostas alérgicas é a anafilaxia, também chamada hipersensibilidade tipo I, mediada por IgE e seu receptor de alta afinidade, FcєRI, que seria análoga ao choque séptico na inflamação tipo I e é 
induzida por ativação excessiva, particularmente quando a resposta ocorre de maneira sistêmica (GOULD et al., 2003; SIMONS, 2007).

A prevalência de doenças como asma, alergia alimentar, angioedema e urticária, alergia a insetos, dermatite atópica, anafilaxia e algumas reações alérgicas a drogas aumentaram muito nas últimas décadas, afetando 30-40\% da população mundial em 2011 de acordo com a "World Allergy Organization" (HOLGATE; POLOSA, 2008; PAWANKAR; CANONICA, 2011). A "hipótese da higiene", primeiramente proposta por STRACHAN (1989), postulou que a falta de desafios microbianos no início da vida, por causa do estilo de vida moderno, aumenta a probabilidade de crianças atópicas de desenvolver uma resposta Th2 a uma variedade de alérgenos ambientais. Isto explicaria o aumento da incidência e prevalência dessas doenças nos grandes centros urbanos (OKADA et al., 2010).

Fica cada vez mais claro que muitos dos sinais clínicos associados às doenças alérgicas é resultante, a longo prazo, de uma inflamação crônica (tipo II) nos locais de exposição persistente ou repetida ao alérgeno. Isto associado aos estudos epidemiológicos que revelam o aumento da incidência e severidade das alergias leva ao entendimento de que essas doenças não são disfunções simples. Ao contrário, as alergias representam doenças complexas e, portanto, mais esforços devem ser voltados para o estudo dos mecanismos básicos de sua indução (EAST, 2011).

Os principais mecanismos responsáveis pela patogênese das alergias foram citados en passant em parágrafos anteriores. As alergias são um conjunto de atividades inflamatórias que produzem os fenômenos mencionados na figura 2, como produção de muco, coceira, aumento da permeabilidade vascular, deposição de colágeno e fibrose, etc, dependendo do local de contato com o alérgeno. Esses sinais são provocados pela ação de células da imunidade "inata" - ativação de macrófagos (pela via alternativa), desgranulação de mastócitos e basófilos, migração e ativação de eosinófilos, por exemplo-, de células epiteliais (muco, hiperplasia) e endoteliais (vasodilatação, edema), da musculatura lisa (diarréia, broncoconstrição) e também de células do sistema nervoso (dor, coceira) (PALM; ROSENSTEIN; MEDZHITOV, 2012a).

A ativação de linfócitos T durante as respostas tipo II, que promovem as ações citadas no parágrafo anterior, é classicamente associada à geração de células Th2 efetoras. Estes linfócitos são caracterizados pela expressão do fator de transcrição GATA-3 (ZHENG; FLAVELL, 1997), dos receptores de quimiocina CCR3, CCR4 e CCR8 (MEDOFF; THOMAS; LUSTER, 2008) e pela intensa produção das citocinas IL-4, IL-5 e IL-13 (ANSEL et al., 2006). Citamos as principais funções dessas citocinas que contribuem para o processo 
inflamatório alérgico: a IL-4 promove a troca de isotipo e produção de IgE nos linfócitos B (MANDLER et al., 1993), a IL-5 é responsável pela maturação, ativação e sobrevivência de eosinófilos (ROTHENBERG; HOGAN, 2006) e a IL-13 induz a produção de muco pela diferenciação e hiperplasia de células epiteliais secretoras especializadas (FINKELMAN et al., 2004). As propriedades gerais de respostas Th2 foram melhor comentadas em revisão recente (PAUL; ZHU, 2010).

A imunoglobulina $\mathrm{E}(\mathrm{IgE})$ é uma das principais moléculas associadas à patogênese das alergias e também às infecções por helmintos. A IgE, chamada antes de reagina, é a imunoglobulina de menor concentração sérica e cuja produção é regulada de forma precisa. Apesar de ser comumente apontada como responsável pela imunopatologia, a IgE desempenha função protetora fundamental (PALM et al., 2013) e, mesmo sendo estudada há quase um século, sua biologia permanece bastante desconhecida, principalmente em humanos. Uma boa revisão sobre os mecanismos de produção e regulação da $\operatorname{IgE}$ pode ser encontrada em WU \& ZARRIN (2014) e a história da descoberta da IgE, assim como do estudo das alergias de modo geral, foi melhor analisada por SILVERSTEIN (2009).

\subsection{Início da inflamação tipo II}

A fase efetora da imunidade tipo II é, no geral, conhecida e bem caracterizada. Contudo, o início dessas respostas ainda não está bem estabelecido e é bastante discutido. $\mathrm{O}$ módulo funcional clássico da imunidade tipo I, baseado no reconhecimento e ativação por DCs e diferenciação de linfócitos T, não parece ser utilizado da mesma forma para indução das respostas Th2. De fato, até a própria participação das DCs na inflamação tipo II já foi tema de intenso debate entre imunologistas há poucos anos (ver Apêndice B). Mais recentemente, dois trabalhos sugeriram que populações "não clássicas" de DCs desempenham função importante no desenvolvimento da imunidade adaptativa tipo II (GAO et al., 2013; KUMAMOTO et al., 2013). Por causa desta descoberta ser bastante recente, ainda se sabe muito pouco sobre a biologia dessas células. Parece que essas DCs se localizam na região subepitelial de mucosas e da pele e são caracterizadas pela expressão dos marcadores de superfície PDL2 (programmed death ligand 2) e CD301b (lectina tipo C) e pelo fator de transcrição IRF4 (interferon-regulatory factor 4). Elas são essenciais na indução da imunidade tipo II, geração de linfócitos Th2 e consequente controle da infecção pelo helminto Nippostrongylus brasiliensis. De maneira interessante, essa população de DCs não responde a estímulos com ligantes de TLR, como LPS e CpG (ligantes do TLR4 e TLR9, 
respectivamente), que sugere realmente se tratar de uma população com função distinta às DCs clássicas, tipo I. No entanto, uma melhor caracterização do desenvolvimento dessa população, sua função na imunidade tipo II e participação nas atividades fisiológicas precisam ser mais estudadas e detalhadas.

Mesmo assim, ainda não foi possível estabelecer um modelo in vitro de indução de linfócitos Th2 a partir da cultura de DCs expostas a alérgenos (ou moléculas provenientes de helmintos), o que sugere a existência de outros mecanismos envolvidos neste tipo de resposta e que difere da resposta Th1.

Além de sua função como barreira física, as células epiteliais tem sido implicadas diretamente na indução de imunidade tipo 2 e são consideradas uma interface crítica entre a imunidade inata e a adaptativa (BULEK et al., 2010a). Algumas observações clínicas levaram à hipótese de que defeitos no epitélio -mutações no gene que codifica a filagrina, por exemplo- seriam os grandes responsáveis pelo desencadeamento de alergias (AINSWORTH, 2011; IRVINE; MCLEAN; LEUNG, 2011).

Uma das maneiras das células epiteliais iniciarem respostas tipo II é pela produção direta das citocinas IL-25, IL-33 e linfopoietina estromal tímica, TSLP (thymic stromal lymphopoietin), em resposta à infecção por helmintos ou exposição à alérgenos (LICONALIMÓN et al., 2013; SAENZ; TAYLOR; ARTIS, 2008). O que estas três citocinas tem em comum é a capacidade de induzir respostas Th2 in vivo. Resumidamente, a IL-25 -ou IL-17Eproduzida pelo epitélio em resposta a alérgenos pode induzir TSLP, migração de eosinófilos (via produção de eotaxina) e formação de muco (ANGKASEKWINAI et al., 2007; FORT et al., 2001). A TSLP, por sua vez, pertence à família da IL-2 e é bastante semelhante à IL-7. Ela é a citocina derivada do epitélio mais bem caracterizada e sua expressão está associada a diferentes formas de inflamação alérgica (YING et al., 2005). Um dos alvos celulares da TSLP é a célula dendrítica que, quando ativada por esta citocina, promove a diferenciação de linfócitos Th2 (SOUMELIS et al., 2002). Por fim, a IL-33, membro da família da IL-1, também está claramente implicada na indução de inflamação alérgica e amplificação da resposta adaptativa Th2. Mostrou-se que a IL-33 é expressa em células epiteliais, onde é constitutivamente armazenada no núcleo. Esta localização é inesperada e ainda não se sabe ao certo como ela é liberada no meio extracelular. No entanto, postulou-se que a IL-33 atua como uma alarmina em caso de exposição a alérgenos, sinalizando uma injúria tecidual e sendo liberada justamente após necrose celular (MOUSSION; ORTEGA; GIRARD, 2008; OBOKI et al., 2010). A IL-33 é membro da família da IL-1 e sinaliza pelo T1/ST2 (codificado por $I l 1 r l 1$ ), um receptor homólogo ao IL-1R que também recruta a molécula 
adaptadora MyD88 (SCHMITZ et al., 2005). De maneira geral, a função dessas citocinas produzidas pelo epitélio fornecem mecanismos para explicar como este tecido pode promover e regular diretamente a resposta imune adaptativa (BULEK et al., 2010b). No entanto, ainda são necessários estudos mais aprofundados das vias celulares e moleculares responsáveis pelas respostas fisiológica e patogênica induzidas pelas superfícies epiteliais mucosas.

Uma população de linfócitos descoberta recentemente pode representar a ligação fundamental e tão procurada entre a estimulação de células epiteliais e o início da resposta Th2. Essas células foram descobertas, em humanos e camundongos, de maneira independente por diversos grupos e, por isto, recebeu nomes variados como nuócitos (NEILL et al., 2010) ou células auxiliares naturais (MORO et al., 2010), entre outros. Para evitar desentendimentos, essas células foram nomeadas células linfóides inatas tipo 2 (innate lymphoid cells type 2, ILC2) (SPITS et al., 2013). Essa população celular faz parte da família das células linfóides inatas, juntamente com as células NK (a partir de agora, chamadas de ILCs do grupo 1 , por secretarem IFN- $\gamma$ ), células $\mathrm{T}$ indutoras de tecidos linfóides $\left(\mathrm{LT}_{\mathrm{i}}\right)$ e as ILC3 (secretam IL-17A e IL-22, principalmente na mucosa intestinal). Essas ILCs são consideradas relacionadas, pois possuem um precursor linfóide tímico comum, que expressa o repressor de transcrição Id2 (transcriptional repressor inhibitor of DNA binding 2), e também requerem a sinalização pela cadeia $\gamma$ comum a vários receptores de citocinas, chamado de $\gamma_{c}$ ou IL-2R $\gamma$, (YOKOTA et al., 1999). As ILC2 são grandes produtoras de IL-5 e IL-13 em resposta às citocinas derivadas do epitélio, como as mencionadas acima, e desempenham função importante na proteção e resistência à infecção por helmintos e ainda na indução da resposta alérgica à cisteíno protease, papaína (HALIM et al., 2014). Uma revisão recente e mais completa sobre a caracterização e função das ILC2 pode ser encontrada em LICONALIMÓN (2013).

\subsection{Indução de alergia por proteases}

Estudos recentes têm relacionado grande parte da atividade alergênica de algumas pragas urbanas, como baratas e ácaros, à presença de proteases em seus respectivos extratos. As proteases têm sido fortemente correlacionadas à asma alérgica e diversos aeroalérgenos freqüentemente implicados na ocorrência da doença são proteases ou estão associados à atividade de protease (KHERADMAND et al., 2002). Entre eles está o principal alérgeno do ácaro Dermatophagoides pteronyssinus Der p 1, estreitamente associado aos casos de asma (PLATTS-MILLS et al., 2009); o Fel d 1, o alérgeno mais comum derivado de gatos 
domésticos, e diversos pólens (BAGAROZZI; TRAVIS, 1998; RING et al., 2000). Fungos também são grandes fontes de proteases ativas e, de acordo com a ideia acima, estão fortemente relacionados a doenças alérgicas (MARKARYAN et al., 1994; RAMESH; SIRAKOVA; KOLATTUKUDY, 1995). Apesar de se saber que vários dos alérgenos potentes são classificados como proteases, seus mecanismos de ação e fisiopatogênese da asma alérgica não estão muito bem estabelecidos (SHAKIB; GHAEMMAGHAMI; SEWELL, 2008).

Uma das hipóteses para explicar o mecanismo de indução de respostas alérgicas por proteases foi publicada recentemente. O grupo propõe que proteases de helmintos e de alérgenos clivam um 'sensor', cuja estrutura ainda não conseguiram identificar, que estimula os basófilos a migrarem para os linfonodos drenantes. Lá, estas células seriam capazes de apresentarem antígenos via MHC de classe II e estimularem a diferenciação de linfócitos Th2, pela produção de citocinas específicas (SOKOL; MEDZHITOV, 2010; SOKOL et al., 2008).

Kouzaki et al mostraram que as proteases induzem o aumento de TSLP a partir do receptor PAR-2 (protease-activated receptor 2), presente nas células epiteliais (KOUZAKI et al., 2009). Os PARs são uma família de receptores acoplados à proteína G e estimulados, preferencialmente, por serino proteases (BLASI; CARMELIET, 2002; REED; KITA, 2004). Até agora quatro tipos foram identificados e suas sequiências, clonadas. Eles estão amplamente expressos nas células endoteliais, tecido conjuntivo, leucócitos, epitélio e em muitas células das vias aéreas (COCKS; MOFFATT, 2001). As proteases clivam aminoácidos num sítio específico da região amino-terminal do receptor e expõe um novo domínio que se liga com um segundo sítio do mesmo receptor iniciando a sinalização. A ativação dos PARs leva ao recrutamento da proteína $\mathrm{G}$, cuja subunidade a $\square$ induz aumento dos níveis de fosfolipase C. Esta, por sua vez, atua aumentando os níveis de um segundo sinal, o $\mathrm{Ca}^{2+}$ intracelular (BERGER et al., 2001; SCHECHTER et al., 1998; UBL et al., 2002). Os detalhes das cascatas intracelulares de transdução de sinal são complexos e podem variar dependendo do subtipo do PAR que é ativado e também das localização desses receptores em diferentes células alvo.

Em camundongos, apenas a administração via intranasal (i.n.) do peptídeo agonista de PAR-2 induziu uma resposta tipo Th2 a um antígeno inócuo, a ovoalbumina (OVA) (EBELING et al., 2007). Verificou-se que tanto a inflamação alérgica pulmonar como a hiperreatividade brônquica (AHR, do inglês, airway hyper-reactivity) estavam diminuídas em camundongos deficientes e aumentadas em animais que expressavam maior quantidade deste receptor (SCHMIDLIN et al., 2002). Apesar de se conhecer como a atividade enzimática é 
reconhecida por esse tipo de receptor, a sinalização que levaria à produção de TSLP e, consequentemente, à polarização para um padrão Th2 ainda não foi totalmente esclarecida.

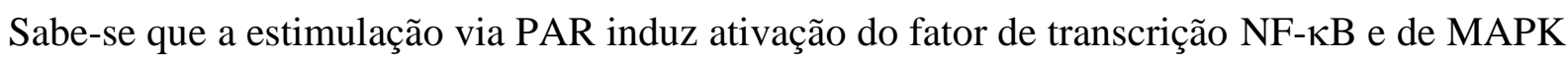
(mitogen-activated protein kinase), que podem induzir a produção de citocinas como IL-1 $\beta$ e TNF- $\alpha$, as quais podem regular a expressão de TSLP (GOON GOH et al., 2008; TEMKIN et

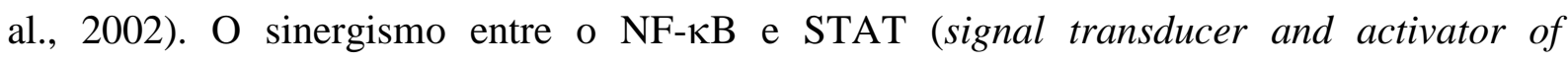
transcription)-6 desempenham participação importante na indução de TSLP em resposta à dsRNA e IL-4 (KATO et al., 2007), e a acetilação de STAT-1 mediada por IFN- $\gamma$ inibe a ativação do NF-кB. Demonstrou-se recentemente que os receptores PARs e TLRs (toll-like receptors) poderiam interagir fisicamente e contribuir com a resposta inflamatória gerada por cada um deles (RALLABHANDI et al., 2008).

\subsection{A asma alérgica}

A origem da palavra asma, em grego, deriva de "vento", "ar" e significa "respiração ruidosa", como discutido por SAUNDERS (1993), que inclusive cita duas passagens do livro Ilíada, de Homero, em que a palavra asma aparece. A asma é uma desordem inflamatória heterogênea das vias aéreas caracterizada pela inflamação crônica e obstrução dessas vias, AHR e por sintomas de espirros, tosses e dificuldade respiratória recorrentes (KIM; DEKRUYFF; UMETSU, 2010). A asma é considerada um grande problema de saúde pública, já que afeta 300 milhões de pessoas no mundo e cuja prevalência aumentou dramaticamente nos últimos 30 anos, principalmente em países ocidentais (WILSON et al., 2006). A asma, no entanto, não é uma doença uniforme e pode se apresentar de formas variadas e com fenótipos distintos, que incluem a asma alérgica, asma severa ou resistente a esteróides (WANG et al., 2010), asma induzida por poluentes ambientais (LI et al., 2003; PICHAVANT et al., 2008), exercício físico (CARLSEN; CARLSEN, 2002), aspirina (WANG et al., 2007), obesidade (SUTHERLAND, 2008), infecções virais (SLY; KUSEL; HOLT, 2010) ou até fumaça de cigarro (ROBAYS et al., 2009).

A forma clínica mais comum da asma é a alérgica e tem sido o principal foco dos tratamentos e das pesquisas das últimas décadas. Segundo os últimos dados do DATASUS do Ministério da Saúde do Brasil, de 2009, a asma se constitui a terceira causa de internação no Brasil quando se trata de crianças e jovens e a prevalência de asma alérgica nesta faixa etária está em torno de 20- 25\% no país (DATASUS, 2009). 
A asma alérgica, ou atópica, é uma síndrome complexa caracterizada, além dos sinais clássicos da asma descritos acima, por intensa secreção de muco, eosinofilia pulmonar e produção de elevados níveis de IgE (KILEY; SMITH; NOEL, 2007). O desenvolvimento deste tipo de asma é essencialmente dependente de linfócitos $\mathrm{T} \mathrm{CD}^{+}{ }^{+}$diferenciados para um padrão Th2 (ROBINSON et al., 1992). Herxheimer et al descreveram as duas fases distintas na resposta asmática após contato com alérgeno (HERXHEIMER, 1952). Na primeira fase, imediata (early phase response), ocorre a broncoconstrição e aumento de permeabilidade vascular que pode se estender por até 3 horas após a inalação do alérgeno. Estas respostas são decorrentes da contração do músculo liso e liberação de mediadores potentes, como histamina, cisteinil leucotrienos e prostaglandinas. Após esta fase, pode ocorrer uma resposta mais tardia que se inicia de 3-6 horas após a exposição ao alérgeno, podendo se estender por mais de 24 horas. Este período foi denominado de resposta asmática tardia (late phase response) e, nesta fase, a participação de linfócitos $\mathrm{T} \mathrm{CD}^{+}$é fundamental. A maioria dos modelos murinos de asma quantificam apenas a hiper-reatividade brônquica de animais alérgicos em resposta à metacolina, um agonista muscarínico (O'BYRNE; GAUVREAU; BRANNAN, 2009). Contudo, poucos conseguiram verificar a ocorrência da fase tardia em resposta ao desafio com alérgeno, sem a indução de um broncoconstritor.

Os corticosteróides inalados (anti-inflamatórios) (BARNES; ADCOCK, 2003) e agonistas do receptor adrenérgico $\beta 2$ (broncodilatadores) (PALMQVIST et al., 1997) ainda constituem o principal tratamento para a asma. Outros tipos incluem os antagonistas de cisteinil leucotrienos (POLOSA, 2007), inibidores de fosfodiesterase cAMP (BOSWELLSMITH; CAZZOLA; PAGE, 2006), anticorpos não anafiláticos anti-IgE (HOLGATE et al., 2005) e imunoterapia alérgeno-específica (LARCHÉ, 2007). Apesar de suprimir a inflamação e aliviar os sintomas respiratórios, a utilização destes medicamentos ainda não representa a melhor estratégia de tratamento para a asma e, assim, é necessário um melhor entendimento da origem das alergias e dos fatores responsáveis pelo aumento da incidência dessas doenças com foco na prevenção e terapias mais eficazes.

\subsection{A asma ocupacional}

A asma ocupacional (AO) é a forma mais comum de doença pulmonar associada ao trabalho. A prevalência de AO depende da natureza química dos agentes aos quais os trabalhadores se expõe, da intensidade da exposição e da susceptibilidade individual (BAUR, 2005; MAESTRELLI et al., 2009). O contato com enzimas em locais de trabalho é um 
importante fator de risco ao desenvolvimento de AO, pricipalmente proteases (BAUR, 2005). Os principais casos de $\mathrm{AO}$ reportados e induzidos por proteases ocorreram no final da década de 60 e durante os anos 70 (CULLINAN et al., 2000), quando a introdução de enzimas alcalinas termo-estáveis bacterianas na formulação de detergentes, como a subtilisina de Carlsberg, promoveu a asma alérgica, produção de $\operatorname{IgE}$ e hiper-reatividade brônquica em mais da metade dos trabalhadores dessas indústrias (SCHWEIGERT; MACKENZIE; SARLO, 2000).

A idéia de se utilizar proteases na indústria foi proposta por Röhm (patente alemã GP283923, 1913), o qual adicionou enzimas pancreáticas a detergentes. A subtilisina de Carlsberg (EC, enzyme classification, 3.4.21.62, i.e.: ), também conhecida como subtilisina A ou alcalase, é uma serino protease derivada de espécies Bacillus e pertence à família A da superfamília das subtilases. Esta enzima representou um dos principais alérgenos responsáveis pelo desenvolvimento de AO (LEMIÈRE et al., 1996) e, no entanto, nenhum modelo experimental de inflamação alérgica pulmonar induzida pela subtilisina foi estabelecido até o presente. Apesar das mudanças nos produtos utilizados nas fábricas, incluindo a substituição da subtilisina por outras proteases alcalinas, o desenvolvimento de AO ainda continua a ocorrer, e milhões de indivíduos estão expostos aos agentes causadores em locais de trabalho (MAESTRELLI et al., 2009). Portanto, este estudo pretendeu estabelecer um modelo murino de asma ocupacional induzida pela subtilisina.

Os trabalhos que relataram a atividade alergênica da subtilisina em modelos animais são bastante escassos, apesar do grande impacto da introdução desta enzima no mercado. Alguns grupos desenvolveram um modelo de sensibilização intratraqueal à subtilisina em cobaias ou camundongos (KAWABATA; BABCOCK; HORN, 1996; RITZ et al., 1993) e apenas um grupo estabeleceu um modelo murino de sensibilização intranasal à subtilisina (ROBINSON et al., 1996). Mesmo assim, nestes trabalhos apenas a produção de anticorpos específicos IgG1 e IgE foi estudada e, além disso, utilizaram uma matriz de detergente como adjuvante à subtilisina. Portanto, não há nenhum relato sobre o efeito da subtilisina sozinha na indução das principais características da asma alérgica, como hiper-reatividade brônquica, resposta tardia ao alérgeno, eosinofilia pulmonar, produção de muco e IgE total. De maneira interessante, a subtilisina foi bastante utilizada em ensaios de espraiamento de macrófagos in vitro (RABINOVITCH; MANEJIAS; NUSSENZWEIG, 1975) e já se sabia que sua atividade enzimática era essencial para esta resposta. Entretanto, o significado fisiológico deste fenômeno, os mecanismos responsáveis pelo espraiamento e sua associação com a indução de alergia ainda não são conhecidos. 
Dessa forma, nossa primeira estratégia para o desenvolvimento de doença alérgica pulmonar e estabelecimento da asma ocupacional foi baseada no modelo clássico e já estabelecido em nosso laboratório (BORTOLATTO et al., 2008) de sensibilização pela via subcutânea (s.c.) utilizando a subtilisina como alérgeno e de desafios pela via intranasal (i.n.) apenas com a enzima. A seguir, desenvolvemos também um modelo de sensibilização pela mucosa nasal (i.n.), que poderia representar outra forma de sensibilização por trabalhadores expostos à enzima e, neste caso, seria mais relevante para o estudo da hipersensibilidade respiratória.

Neste trabalho, descrevemos a caracterização do modelo experimental de asma ocupacional induzida pela sensibilização, via subcutânea ou intranasal, à subtilisina. Verificamos que a atividade de serino protease desta enzima é essencial para a sensibilização alérgica e consequente inflamação das vias aéreas induzida pela subtilisina. Demonstramos a participação crucial dos receptores PAR-2, ST2 (subunidade do receptor de IL-33) e IL-1R, assim como da molécula adaptadora MyD88 na indução de respostas alérgicas à subtilisina. Mostramos também que a subtilisina não é capaz de induzir ativação clássica direta de células dendríticas (DCs) ou macrófagos. Em vez disto, sua ação alergênica deve estar associada à produção de citocinas derivadas do epitélio, pois verificamos o aumento da expressão de TSLP, IL-1 $\alpha$, IL-33 e anfiregulina por células humanas epiteliais brônquicas em resposta à exposição por subtilisina em ensaio in vitro. Finalmente, a administração de subtilisina pelas vias aéreas induziu o aumento de células inatas linfóides tipo 2 (ILC2) e ainda atuou como adjuvante a um antígeno não correlacionado, como a OVA. 


\subsection{Hipótese principal}

A atividade de serino protease da subtilisina é essencial no desenvolvimento da resposta alérgica pulmonar e essa atividade é reconhecida no organismo pelo receptor PAR(protease-activated receptor)-2.

\subsection{Objetivos}

1. Estabelecer um modelo de alergia pulmonar induzida pela subtilisina e caracterizar a imunidade adaptativa $\operatorname{Th} 2$;

2. Verificar a necessidade do uso de adjuvante durante a sensibilização à subtilisina e testar se ela própria poderia atuar como um adjuvante a uma outra proteína, não relacionada;

3. Determinar a participação da atividade enzimática da subtilisina no desenvolvimento da resposta alérgica;

4. Investigar os mecanismos "inatos" responsáveis pela indução de inflamação tipo II à subtilisina. 
3 METODOLOGIA 


\subsection{Animais}

Camundongos fêmeas (8-12 semanas de idade) C57BL/6 WT, TLR4 ${ }^{-/-}$, MyD88 ${ }^{-/-}$, $\mathrm{PAR}^{-2^{--}}, \mathrm{Il1} 1 \mathrm{rl}^{-/-}$(gentilmente fornecido por Andrew McKenzie, Universidade de Cambridge e também conhecidos como ST2 ${ }^{-/}$), $\mathrm{IL}_{-1 \mathrm{R}^{-/-}}$(gentilmente cedido por Dario Zamboni, Universidade de São Paulo) e BALB/c foram fornecidos e mantidos pelo biotério de animais isogênicos e de experimentação do Departamento de Imunologia do Instituto de Ciências Biomédicas da Universidade de São Paulo (ICB-USP, Brasil), ou pelo Yale Animal Resources Center da Universidade de Yale (Estados Unidos). Os animais foram mantidos em condições livres de patógenos específicos (SPF) e os experimentos foram realizados de acordo com as diretrizes aprovadas e determinadas pelos princípios éticos do Comitê de Ética em Experimentação Animal (CEEA) adotados pela Sociedade Brasileira de Ciência de Animais de Laboratório (SBCAL) e também do Institutional Animal Care and Use Committee at Yale University.

\subsection{Reagentes e anticorpos}

A serino protease subtilisina de Carlsberg (EC, enzyme classification, 3.4.21.62), cisteíno protease papaína (EC 3.4.22.2) de Carica papaya, OVA grau II ou V, e LPS (Escherichia coli O111:B4) foram todos adquiridos da Sigma-Aldrich Corporation (EUA). O PMSF (phenylmethylsulfonyl fluoride) (Sigma-Aldrich), E-64 (trans-epoxysuccinyl Lleucylamido(4-guanidine)butane) (Calbiochem Merck Millipore, EUA) e substratos fluorogênicos, Ala-Ala-Phe 7-amido-4-metilcoumarina (AMC) e carbobenzoxi-arginina-7amido-4-metilcoumarina (Z-R-AMC) (Calbiochem), foram gentilmente cedidos pela professora Clélia Ferreira do Departamento de Bioquímica do IQ-USP. O BrdU (5-bromo-2deoxyuridine) foi adquirido da Life Technologies. A OVA foi removida de endotoxina utilizando o Triton X-114 (Sigma-Aldrich) como estabelecido anteriormente (AIDA; PABST, 1990) e a atividade remanescente foi quantificada pelo kit LAL QCL-1000 (BioWhittaker). Os seguintes anticorpos específicos, conjugados a fluorocromos variados, para camundongos ou humanos, utilizados foram todos da BD Biosciences ou eBioscience: CD16/CD32 (2.4G2), I-A ${ }^{\mathrm{d}}$ e I-E ${ }^{\mathrm{d}}$, Siglec-F, Gr1 (Ly6G), CD3e, CD4, CD8 $\alpha$, CD19, CD45, CD80, CD83, CD86, IL-2, IL-4, IL-5, IL-13, IL-10, IL-17A, IFN- $\gamma$, TNF- $\alpha$, CD11b, CD11c, NK1.1, FceRI, Thy1.2 (CD90.2), c-kit (CD127), CCR9, HLA-DR, Gata-3, Rorc, T-bet e Foxp3. O anticorpo específico para T1/ST2 conjugado foi adquirido da MD Bioproducts (EUA). 


\subsection{Determinação da concentração e integridade das proteases}

Para quantificação de proteína utilizamos o método de determinação com ácido bicinchonínico (BCA), como descrito anteriormente (SMITH et al., 1985). Também determinamos a concentração da enzima em solução aquosa utilizando o coeficiente de extinção molar conhecido a $280 \mathrm{~nm}, \varepsilon_{280}=23,46 \mathrm{mM}^{-1} \mathrm{~cm}^{-1}$ no espectrofotômetro GeneQuant $^{\mathrm{TM}} 1300$ (GE Healthcare BioSciences) ou ainda pelo ensaio de quantificação protéica da Bio-Rad (Kit II), baseado no método de Bradford, que utiliza uma solução de Comassie ${ }^{\circledR}$ Brilliant Blue G-250 e se liga primariamente a resíduos de aminoácidos básicos e aromáticos, especialmente a arginina. Como curva padrão utilizamos uma solução de concentração conhecida de albumina sérica bovina (BSA), cuja variação linear é 0.2 to 1.5 $\mathrm{mg} / \mathrm{ml}$. A integridade da subtilisina após diluição foi verificada por eletroforese, pela técnica de SDS-PAGE (sodium dodecyl sulfate-polyacrylamide gel electrophoresis) e foi realizada em géis de acordo com LAEMMLI (1970), como detalhado por FERREIRA et al. (2001). A coloração para proteína foi feita pelo método de impregnação por prata. Utilizamos os seguintes padrões de massas: lisozima $(14,4 \mathrm{kDa})$, inibidor de tripsina de soja $(21,5 \mathrm{kDa})$, anidrase carbônica (31 kDa), OVA (45 kDa), BSA (66 kDa) e fosforilase b (97,4 kDa).

\subsection{Ensaios de atividade e inibição enzimática}

A atividade enzimática das proteases foi rotineiramente avaliada e determinada como descrito por Zewail et al. (PAL; PEON; ZEWAIL, 2002). O ensaio foi realizado em placa de 96 poços em salina com $5 \mathrm{mM} \mathrm{Ca}{ }^{2+} \mathrm{Cl}$ ou PBS com $5 \mathrm{mM}$ L-cisteína (ambos em pH=7,4), subtilisina ( $5 \mu \mathrm{g} / \mathrm{mL}$ ) ou papaína $(25 \mu \mathrm{g} / \mathrm{mL}$ ) e substrato (AMC para subtilisina ou Z-R-AMC para papaína, ambos a $150 \mathrm{nM}$ ). A emissão de fluorescência a $460 \mathrm{~nm}$ foi obtida a cada 3 ou 5 min durante $1 \mathrm{~h}$ a $37{ }^{\circ} \mathrm{C}$ no espectrofotômetro SpectraMax M2 (MDS Analytical Technologies) e os resultados foram expressos como a razão da emissão da fluorescência por tempo (atividade remanescente). As atividades proteásicas foram proporcionais à concentração de enzima e ao tempo.

Para inibição da atividade as proteases foram termicamente inativadas após incubação por $5 \mathrm{~min}$ a $100{ }^{\circ} \mathrm{C}$ em um microtubo de polipropileno, conforme curva de atividade por temperatura fornecida pelo fabricante. Determinamos a concentração protéica e atividade remanescente no sobrenadante e precipitado após centrifugação a $10.000 \mathrm{x}$ g à $4{ }^{\circ} \mathrm{C}$. Alternativamente, a subtilisina ou papaína foram incubadas com diferentes concentrações de 
PMSF e E-64, respectivamente, até que nenhuma atividade pudesse ser detectada previamente ao ensaio enzimático. Para os estudos in vivo, utilizamos $5 \mu \mathrm{M}$ de PMSF e $50 \mathrm{nM}$ de E-64. Como estes inibidores precisam ser solubilizados em solventes orgânicos também realizamos ensaios de atividade in vitro e experimentos in vivo com as mesma concentrações finais dos solventes. Utilizamos EtOH e DMSO para soluções de PMSF e E-64, respectivamente, numa concentração final de $0,5 \%$ v/v. Cabe ressaltar que a atividade enzimática da subtilisina ou da papaína não foram alteradas após adição dos respectivos solventes.

\subsection{Preparo do gel de hidróxido de alumínio (alum)}

$\mathrm{O}$ gel $\left(\mathrm{Al}(\mathrm{OH})_{3}\right)$ foi preparado como descrito anteriormente (BORTOLATTO et al., 2008). Resumidamente, precipitou-se 0.184 M de sulfato de amônio alumínio $\left(\mathrm{AlH}_{4} \mathrm{NO}_{8} \mathrm{~S}_{2} .12 \mathrm{H}_{2} \mathrm{O}\right)$ em $1 \mathrm{M} \mathrm{NaOH} . \mathrm{O} \mathrm{Al}(\mathrm{OH})_{3}$ foi suspenso em água Milli Q e lavado 5 vezes a $3000 \mathrm{rpm}$ por 15 min. O precipitado final foi dissolvido em água e a concentração de $\mathrm{Al}(\mathrm{OH})_{3}$ foi calculada pela determinação do peso seco em $1 \mathrm{~mL}$ de solução. Para a imunização a solução estoque do alum foi solubilizada em PBS para uma concentração final de $1,6 \mathrm{mg}$ de alum por animal.

\subsection{Protocolos experimentais de inflamação alérgica das vias aéreas}

O estabelecimento de asma ocupacional induzida por subtilisina foi realizado baseado em protocolo experimental já padronizado (RUSSO et al., 2001), que utiliza a OVA adsorvida em alum na sensibilização subcutânea (s.c.), para induzir a inflamação alérgica, e a proteína sem adjuvante no desafio intranasal (i.n.), para direcionar a resposta inflamatória às vias aéreas. Portanto, os animais foram sensibilizados com $1 \mu \mathrm{g}$ de subtilisina com ou sem alum pela via s.c. e com $1 \mu \mathrm{g}$ da enzima no desafio i.n., como mostrado a seguir (protocolo 1). Como comparação, outro grupo recebeu $10 \mu \mathrm{g}$ de papaína, uma protease associada à ocorrência de alergias ocupacionais em humanos (NOVEY; MARCHIOLI; SOKOL, 1979). No estudo da participação da atividade enzimática das proteases no desenvolvimento da resposta alérgica, os animais receberam a protease inativa (subtilisina/PMSF ou papaína/E64), sem alum, durante a sensibilização s.c., mas foram desafiados com a forma ativa das respectivas proteases, seguindo o protocolo 1. 


\section{Protocolo 1:}

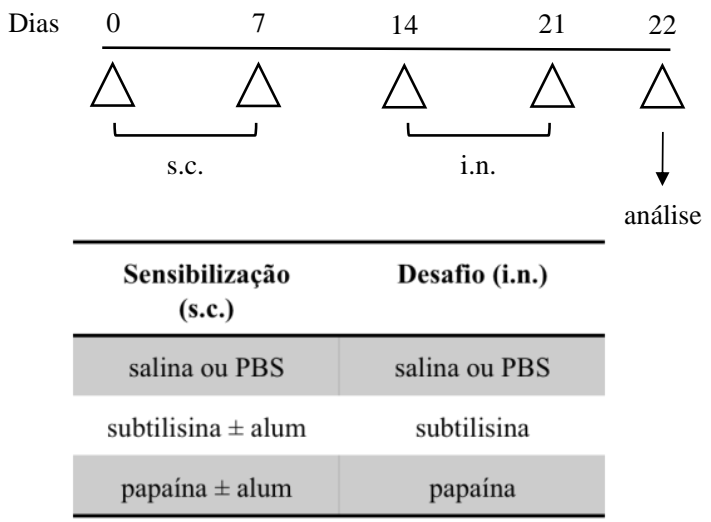

Para caracterização das células linfóides inatas tipo 2 (ILC2) no pulmão em resposta à subtilisina, os animais receberam $1 \mu \mathrm{g}$ da protease por via i.n. durante 3 dias consecutivos (protocolo 2). A coleta e as análises foram realizadas $24 \mathrm{~h}$ após a última exposição à subtilisina. A caracterização inicial das ILC2 foi realizada pela administração de $0,4 \mu \mathrm{g}$ de IL25 (IL-17E) murino recombinante (R\&D) nas vias aéreas por 3 dias consecutivos, de maneira semelhante ao protocolo 2.

Protocolo 2:

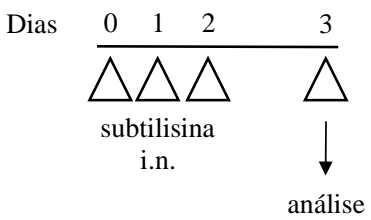

A indução da inflamação alérgica por sensibilização intranasal foi realizada seguindo o protocolo 3, mostrado a seguir, e consistiu em duas administrações i.n. de $1 \mu \mathrm{g}$ de subtilisina nos dias 0 e 7 . Os experimentos foram realizados no dia 8 e o grupo controle recebeu salina. 


\section{Protocolo 3:}

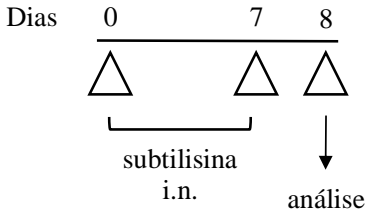

A capacidade adjuvante da subtilisina no desenvolvimento da resposta alérgica à OVA foi testada da seguinte maneira: animais foram sensibilizados com $5 \mu \mathrm{g}$ de OVA, $1 \mu \mathrm{g}$ de subtilisina, OVA e subtilisina ou OVA e subtilisina inativada termicamente (i-subtilisina) nos dias 0 e 7. Todos os grupos foram desafiados por via i.n. com $10 \mu \mathrm{g}$ de OVA, como mostrado no protocolo 4, abaixo.

\section{Protocolo 4:}

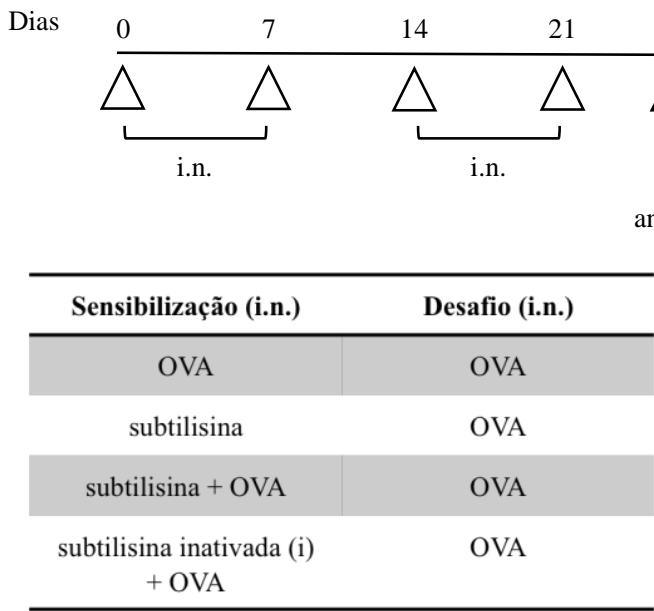

\subsection{Análise da resposta inflamatória alérgica}

O número total de células presentes no lavado broncoalveolar (BAL) foi determinado pela coloração com cristal violeta a $0,5 \%$ em ácido acético (30\%) em hemocitômetro (câmara de Neubauer) ou pelo citômetro de fluxo, Accuri (BD Biosciences). Para determinação da viabilidade celular e contagem de células do pulmão (após digestão e isolamento) e epiteliais da linhagem H292, utilizou-se uma solução 0,4\% de Trypan Blue (Sigma). A caracterização morfológica celular foi realizada após citocentrifugação do BAL, fixação e coloração com 
eosina e hematoxilina- H/E (kit InstantProv, PR-Brasil). Foram contadas 200 células por lâmina, com o auxílio de microscópio óptico com objetiva de imersão (100x), e os tipos celulares foram classificados pela característica morfológica em: mononucleares, neutrófilos, eosinófilos ou mastócitos.

Para análise do infiltrado celular no pulmão e da produção de muco, este órgão foi perfundido com 5-10 mL de PBS pelo ventrículo direito do coração de animais anestesiados e sacrificados. A seguir, removeu-se os lobos pulmonares que foram colocados em solução fixadora (formalina 10\% ou paraformaldeído 4\% em PBS) para futura análise histológica ou em meio RPMI 10\% SFB, para processamento e isolamento das células, como descrito a seguir. Após 24 h em solução fixadora, os lobos foram imersos em solução de EtOH $70 \%$ até serem colocados em parafina. Os tecidos foram fatiados e secções de $5 \mu \mathrm{m}$ foram coradas com eosina e hematoxilina (H/E) ou ácido periódico de Schiff (PAS) e hematoxilina para determinação do infiltrado celular no tecido e produção de muco pelo epitélio brônquico, respectivamente.

O tecido pulmonar fresco foi digerido com $2 \mathrm{mg} / \mathrm{mL}$ de colagenase tipo IV e $1 \mathrm{mg} / \mathrm{mL}$ de desoxiribonuclease I (DNase I), ambos da Sigma-Aldrich, em meio RPMI e incubado a 37 ${ }^{\circ} \mathrm{C}$ por 30 min. Uma suspensão de células isoladas foi obtida após maceração, filtragem e depleção de eritrócitos por tampão de lise (ACK, Life Technologies). Células pulmonares totais foram re-estimuladas ex vivo com $100 \mathrm{ng} / \mathrm{mL}$ de PMA e $750 \mathrm{ng} / \mathrm{mL}$ de ionomicina (Sigma) por $4 \mathrm{~h}$ ou com $1 \mu \mathrm{g} / \mathrm{mL}$ de subtilisin por $16 \mathrm{~h}$, ambos em meio completo RPMI1640 a $37^{\circ} \mathrm{C}$.

\subsection{Caracterização fenotípica de populações celulares}

Para análise da expressão de marcadores de superfície, utilizamos 1,0 x $10^{6}$ células de BAL ou pulmão para cada amostra e, para a marcação intracelular, utilizamos de 3,0 a 5,0 x $10^{6}$ células de pulmão por amostra. Resumidamente, as células isoladas do BAL ou pulmão foram incubadas com bloqueador de receptores Fc $\gamma$ (anti CD16/CD32, clone 2.4G2) e depois por 25 min a $4{ }^{\circ} \mathrm{C}$ com anticorpos específicos para as moléculas de interesse, marcados com fluorescências variadas. Para a marcação intracelular de citocinas e/ou fatores de transcrição utilizamos o kit Cytofix/Cytoperm Plus with GolgiPlug (BD Pharmingen) após a marcação extracelular de acordo com instruções do fabricante. Especificamente para a marcação intracelular de Foxp3 (eBiosciences), foi utilizado um kit de permeabilização específico da BD Pharmingen, conforme intruções do fabricante. 
A aquisição das células foi realizada nos instrumentos LSRII ou FACS Canto (BD Biosciences) e os resultados foram analisados com o software FlowJo (TreeStar).

Para análise da migração de granulócitos às vias aéreas por citometria de fluxo, as populações celulares do BAL e pulmão foram selecionadas como mostrado a seguir, num exemplo de amostra de animal C57BL/6 sensibilizado e desafiado com subtilisina ativa e , portanto, alérgico, utilizando apenas marcadores de superfície. As seleções foram baseadas em amostras controles, da sensibilização alérgica (portanto, animais que receberam apenas salina) ou da marcação específica de cada ensaio (controle isotípico).

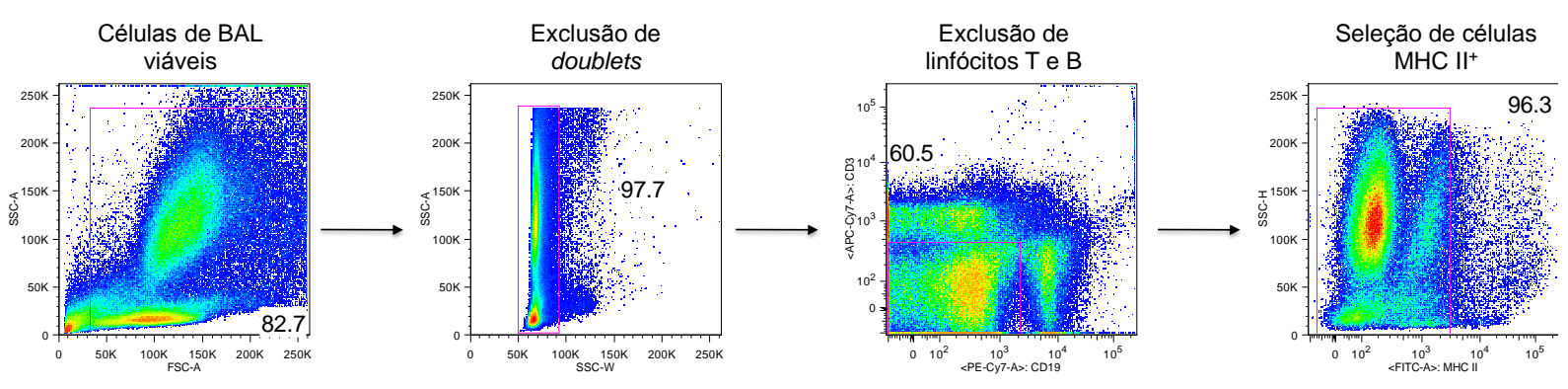

A análise da produção de citocinas intracelular ou da expressão de fatores de transcrição foram analisados em células isoladas de pulmão, como descrito anteriormente, e a estratégia da seleção das populações celulares está representada a seguir (no exemplo, amostra de pulmão derivado de C57BL/6 alérgico à subtilisina).

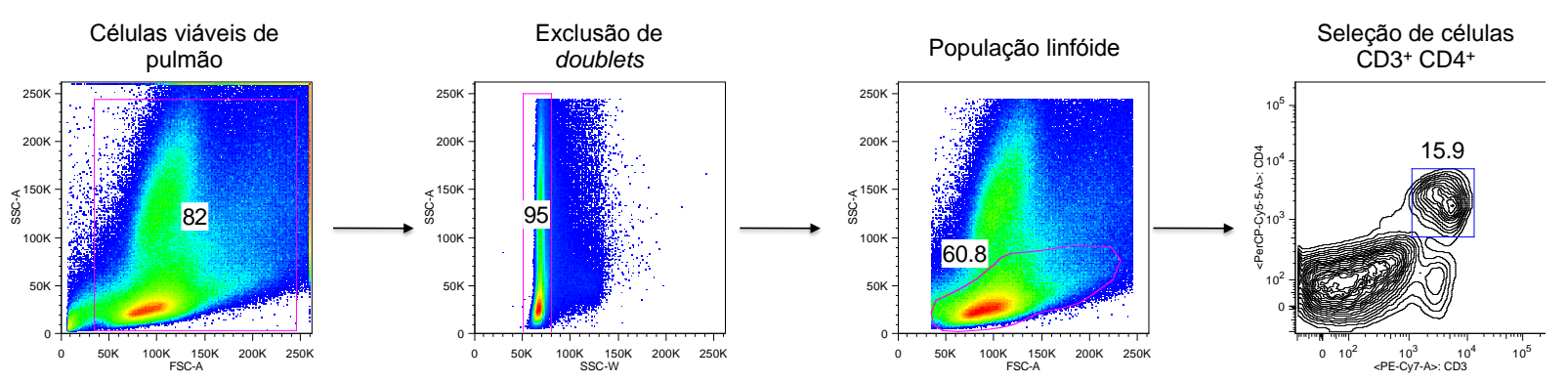


As células linfóides inatas tipo 2 (ILC2) foram analisadas a partir de amostras de pulmão e após administração intranasal de IL-25 recombinante ou subtilisina ativa, conforme representado no protocolo 2. A estratégia de seleção das populações celulares do pulmão para análise por citometria de fluxo está mostrada a seguir.
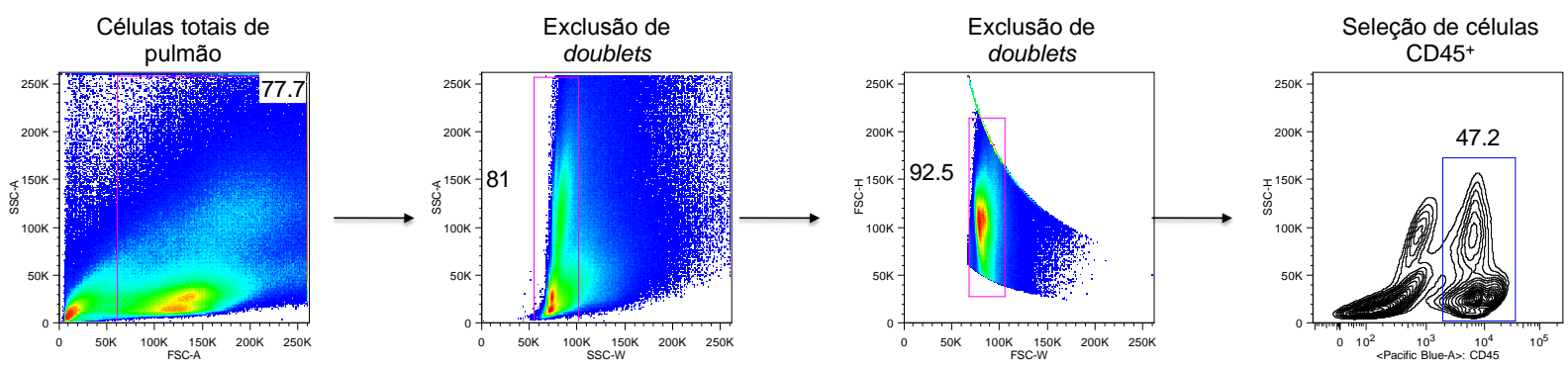

A proliferação celular foi determinada a partir da administração in vivo do reagente BrdU (5-bromo-2-deoxiuridina), de acordo com instruções do fabricante (Life Technologies). Resumidamente, animais C57BL/6 receberam uma solução de $\operatorname{BrdU}$ (1mL do reagente concentrado por $100 \mathrm{~g}$ de peso corpóreo) via intraperitoneal por 3 dias consecutivos, como no protocolo 2. A marcação do BrdU nas células pulmonares, indicativo da proliferação celular, foi analisada no dia 4 por citometria de fluxo.

\subsection{Determinação da função respiratória}

A reatividade brônquica foi analisada após o primeiro e/ou segundo desafios alergênicos, para a maioria dos protocolos experimentais descritos anteriormente. Avaliamos a função pulmonar em animais livres e conscientes colocados em câmaras plestismográficas (BUXCO Eletronics Inc. Wilmington, USA) individuais como descrito previamente (KELLER et al., 2006) e um dos parâmetros respiratórios analisados foi o aumento na pausa respiratória (Penh), calculado segundo instruções do fabricante.

\section{Penh $=($ Te/Tr-1) $\times$ Pef/Pif}

Penh; "enhanced pause"; Te: tempo expiratório (segundos); Tr: tempo de relaxamento (segundos); Pef: pico de fluxo expiratório e Pif: pico de fluxo inspiratório, segundo instruções do fabricante como descrito. Os gráficos relativos à função respiratória estão representados como área sobre a curva (AUC) dos valores de Penh. 
Apesar deste método não-invasivo ser considerado controverso, foi estabelecido que a medida do Penh após 1 ou 2 desafios em animais C57BL/6 com OVA i.n. está fortemente correlacionada à resistência e complacência pulmonar (ALBERTINE et al., 2002). O valor de Penh foi determinado de duas maneiras, baseado em protocolo descrito anteriormente (HOPFENSPIRGER et al., 2001): 1) em resposta a doses crescentes (0, 3, 6, 12 e $25 \mathrm{mg} / \mathrm{mL})$ de metacolina (MCh, Sigma-Aldrich)- um agonista muscarínico - nebulizada diretamente nas câmaras (para avaliar a reatividade pulmonar em resposta à estímulo com broncoconstritor) ou 2) em resposta ao desafio antigênico diretamente sem estímulo com broncoconstritor para avaliar a resposta de fase tardia. No primeiro caso, os resultados foram gravados por 7,5 min (5 min durante e 2,5 min após) para cada nebulização com MCh e registrou-se a média dos valores de Penh. No segundo caso, avaliou-se a função pulmonar basal nas primeiras 6 horas após a exposição ao alérgeno. Para análise da resposta tardia (late phase response) foi necessário esperar o efeito da anestesia provocado pelo $2^{\circ}$ desafio via i.n., no dia 21 , (geralmente, de 3 a 4 horas após a injeção i.p.).

\subsection{Detecção de anticorpos totais e específicos}

A concentração de anticorpos IgE no soro de animais foi determinada seguindo as instruções do fabricante (BD OptEIA ELISA Set). Resumidamente, placas de 96 poços específicas (Nunc MaxiSorp ${ }^{\circledR}$ eBioscience) foram incubadas com anticorpo de captura (anti IgE de camundongo) pernoite a $4{ }^{\circ} \mathrm{C}$. As placas foram bloqueadas com uma solução de $10 \%$ SFB em PBS, o soro coletado de cada amostra foi adicionado em diferentes diluições $(10,50$ e 100x) e a IgE total foi detectada com um anticorpo anti IgE biotinilado e estreptoavidina conjugada com peroxidase (HRP). A IgE total de camundongo purificada foi utilizada como padrão.

Para a quantificação de IgG1 específico realizamos um ELISA indireto que consistiu, resumidamente nas seguinte etapas: incubou-se $2 \mu \mathrm{g} / \mathrm{mL}$ do antígeno (subtilisina, papaína ou OVA) pernoite a $4{ }^{\circ} \mathrm{C}$. Após o bloqueio com SFB $10 \%$, o soro foi adicionado em concentrações variadas (de 1.000 a 40.000x) e anticorpos IgG1 específicos foram detectados com anti IgG1 de camundongo HRP (Invitrogen). IgG1 purificado (Invitrogen) de camundongo foi utilizado como padrão. A determinação de anticorpos IgE específicos para OVA foi realizada pela incubação de anticorpos de captura anti IgE (SouthernBiotech) e, após o soro (diluição 10-100x), adicionou-se OVA marcada com biotina. A reação foi revelada e os níveis de IgE específicos para OVA presentes nas amostras de soro foram deduzidas a partir 
de um padrão interno (soro hiperimune), arbitrariamente atribuído um valor máximo de 1000 unidades (AU), como previamente descrito por nosso grupo (RUSSO et al., 2001).

\subsection{Quantificação de citocinas}

O perfil de citocinas produzidas no BAL ou em sobrenadantes de cultura foi caracterizado por ELISA sanduíche ou pelo CBA (cytometric bead array) ambos da BD Biosciences e seguindo as instruções específicas de cada protocolo, $\mathrm{BD}^{\mathrm{TM}}$ OptEIA ELISA Set Kit e BD ${ }^{\mathrm{TM}}$ CBA Mouse Th1/Th2/Th17 Cytokine Kit, respectivamente. O princípio deste último ensaio baseia-se na captura de analitos (no caso, citocinas) por microesferas (beads) de tamanhos e fluorescências conhecidos o que permite a detecção de diferentes analitos numa mesma amostra (utilizamos $25 \mu \mathrm{L}$ de BAL) . Para os nosso experimentos, utilizamos um painel capaz de quantificar simultaneamente IL-2, IL-4, IL-6, IL-10, IL-17A, IFN- $\gamma$ e TNF- $\alpha$. $\mathrm{O}$ reagente de detecção é uma mistura de anticorpos conjugados à ficoeritrina (phycoerythrin ou PE), que fornece o sinal fluorescente proporcional à concentração da citocina ligada. As amostras foram quantificadas no citômetro de fluxo FACS Canto II (BD Biosciences) e analisadas pelo sofware FCAP array $^{\mathrm{TM}}(\mathrm{BD})$.

\subsection{Análise da ativação de células epiteliais}

Células humanas epiteliais brônquicas de linhagem (H292) (mucoepidermoid pulmonary carcinoma) foram cultivadas com meio RPMI completo como indicado pelo fabricante (ATCC) e utilizadas após 20 passagens, no máximo, de cultivo para os experimentos. Para os experimentos de estimulação com proteases, as células H292 foram incubadas com meio sem soro por um dia, lavadas e as soluções de meio sem soro com as concentrações indicadas de protease foram adicionadas às placas com as células aderidas e viáveis. As células $\mathrm{H} 292$ foram estimuladas com a forma ativa das proteases, subtilisina ou papaína, por 3 ou 6 horas. Foram testadas diversas concentrações de enzima e escolhemos as que não alteravam a viabilidade e aderência das células no tempo específico do ensaio. Os ensaios foram realizados em triplicatas.

O efeito da exposição às enzimas nas células H292 foi avaliado pela expressão de citocinas pró-alérgicas (IL-1 $\alpha$, IL-25, IL-33, TSLP), proteína de reparo tecidual (anfiregulina ou Areg) e mucina (MUC5b) por PCR em tempo real (qPCR). Brevemente, o RNA total foi isolado utilizando-se o reagente RNA-Bee (AMS Biotechnology) e foi reversamente 
transcrito com um iniciador oligo (dT) e transcriptase reversa (RT) M-MLV (moloney murine leukemia virus reverse transcriptase). O DNA complementar foi sintetizado pela SuperScriptIII (Roche) e iniciadores aleatórios, e analisado em triplicata por amplificação qPCR utilizando a SYBR Green Supermix (Qiagen ou Quanta) no equipamento Bio-Rad

CFX96 Real-Time PCR Detection System. A expressão relativa $\left(2^{-\Delta \Delta c t}\right)$ foi normalizada pela expressão de Rpl22a, que codifica a proteína ribossonal L22. Os resultados são representados como a expressão relativa sobre células não estimuladas e são representativos de três experimentos, com amostras em triplicata em cada um deles.

\subsection{Diferenciação de células dendríticas humanas (hDCs) e polarização de linfócitos T}

Os seguintes experimentos foram realizados em colaboração com o Laboratório de Imunologia de Tumores do Prof. José Alexandre Marzagão Barbuto, do Departamento de Imunologia da Universidade de São Paulo.

\subsubsection{Participantes do Estudo}

Três indivíduos (mulheres) não atópicos e não fumantes com idades entre 23-34 anos, sem histórico familiar de asma ou outra doença alérgica participaram do estudo como doadores de sangue. O consentimento de todos os participantes foi obtido e o estudo foi aprovado pelo Comitê de Ética Humana Institucional (2009/902 CEP).

\subsubsection{Diferenciação e estimulação in vitro de hDCs}

As hDCs foram geradas como descrito previamente por nosso grupo colaborador (RAMOS et al., 2012). Para a purificação de células mononucleares, cerca de $30 \mathrm{~mL}$ do sangue foram coletados, diluídos em PBS estéril e colocados em tubos plásticos cônicos de 50 $\mathrm{mL}$, aos quais foram acrescentados, no fundo do tubo, $12 \mathrm{~mL}$ de Ficoll-Paque. O material foi submetido a um gradiente de centrifugação, primeiramente a $900 \mathrm{~g}$ por 30 minutos, a $18^{\circ} \mathrm{C}$. A camada de células mononucleares formada foi retirada, colocada em outro tubo juntamente com meio de cultura RPMI e centrifugada a $600 \mathrm{~g}$ por $10 \mathrm{~min}$, e posteriormente lavadas por mais 2 vezes a 300 g e 200 g, respectivamente, para eliminação das plaquetas. O pellet celular foi coletado, as células quantificadas, ressuspendidas em meio RPMI-1640 suplementado com 10\% de SBF (R-10; Sigma) acrescido de antibiótico-antimicótico (100 U/ml penicilina, 100 
$\mu \mathrm{g} / \mathrm{ml}$ estreptomicina e $25 \mu \mathrm{g} / \mathrm{ml}$ anfotericina, Gibco, EUA) e colocadas em placa de cultura de 6 poços, na concentração de $1 \times 10^{7} / \mathrm{mL}$ e foram mantidas em estufa de $\mathrm{CO}_{2}$ em período overnight (de 15-18hs) a $37^{\circ} \mathrm{C}$, para aderência. Após esse período, as células não-aderentes foram retiradas e fenotipadas ou congeladas a $-70{ }^{\circ} \mathrm{C}$ com DMSO e as aderentes cultivadas por 7 dias em meio R-10 acrescido de 50 ng/mL de IL-4 e 50 ng/mL de GM-CSF. Para a obtenção DCs maduras, utilizadas em alguns experimentos, foi adicionado $50 \mathrm{ng} / \mathrm{mL}$ de TNF$\alpha$ no quinto de cultura como estímulo de maturação. Após o período de cultura, as placas foram submetidas a um banho de gelo por cerca de 10 minutos, para facilitar a retirada e coleta das células aderentes. Estas foram lavadas em meio RPMI e testadas em sua viabilidade por sua capacidade de excluir o azul de Trypan $(0,4 \%)$, em seguida foram submetidas à análise fenotípica por citometria de fluxo, assim como, utilizadas para os demais ensaios do estudo. Todas as citocinas recombinantes foram adquiridas da R\&D).

\subsubsection{Polarização de linfócitos $T$}

No dia 6, as hDCs imaturas (mo-iDCs) foram estimuladas com $1 \mu \mathrm{g} / \mathrm{mL}$ de subtilisina ativa ou inativada termicamente (iSt), ou $50 \mathrm{ng} / \mathrm{mL}$ de LPS e incubadas por $18 \mathrm{~h}$. No dia 7, as células, chamadas agora de Mo-mDCs (células dendríticas maduras) foram incubadas com marcadores de superfície específicos e analisadas por citometria de fluxo. Sete dias após a diferenciação in vitro das hDCs, células mononucleares não aderentes foram isoladas de sangue heparinizado de um doador diferente. As Mo-mDCs pulsadas com a subtilisina ativa, inativa ou LPS foram co-cultivadas com as células mononucleares heterólogas, em triplicata e a uma razão de 1:10 com 0,2 mL por poço de meio RPMI-1640 sem soro. As células foram incubadas a $37^{\circ} \mathrm{C}$ a $5 \% \mathrm{CO} 2$ por 5 dias para permitir proliferação. Então, os sobrenadantes de cultura foram coletados e utilizado para quantificação de citocinas e as células foram reestimuladas para marcação intracelular como descrito na seção $\mathbf{3 . 8}$ Caracterização fenotípica de populações celulares.

\subsection{Análises estatísticas}

As análises estatísticas foram realizadas com teste t (Mann-Whitney para dados não pareados) ou ANOVA, como apropriado. As diferenças foram consideradas significantes quando o valor de $\mathrm{p}<0,05(*), \mathrm{p}<0.01(* *)$ ou $\mathrm{p}<0.005(* * *)$ relativo ao grupo controle ou $(\bullet)$ para diferenças relativas a outro grupo experimental, de acordo com o protocolo utilizado. 


\subsection{Modelo experimental de alergia pulmonar induzida por subtilisina}

A fim de analisar o potencial alergênico da subtilisina in vivo e desenvolver um modelo de asma ocupacional, o protocolo experimental clássico de alergia pulmonar à OVA foi aplicado em camundongos fêmeas C57BL/6. Este protocolo consiste em duas injeções por via s.c. do alérgeno adsorvido em alum nos dias 0 e 7 e dois desafios via i.n. nos dias 14 e 21 (RUSSO et al., 2001). Como as proteases, em geral, são alérgenos que não necessitam de adjuvante para induzirem uma resposta alérgica - tipo II, de acordo com classificação proposta anteriormente (KHERADMAND et al., 2002) -, outro grupo de animais recebeu apenas a subtilisina sem alum durante a fase da sensibilização (protocolo 1).

Como mostrado na figura 3, a sensibilização com subtilisina em alum e posterior desafio induziram o aumento do número total de células presentes no BAL em relação ao grupo controle e este aumento foi ainda maior no grupo sensibilizado apenas com a enzima na ausência de adjuvante (figura 3A). Verificamos, pela análise morfológica das células presentes no BAL, o aumento de células mononucleares (principalmente monócitos/macrófagos e linfócitos), neutrófilos e, particularmente, de eosinófilos nos grupos que receberam subtilisina (figura 3B). $\mathrm{O}$ aumento dessas populações celulares foi um pouco mais discreto no grupo sensibilizado com subtilisina em alum, mas foi significativo em relação ao grupo controle, que recebeu apenas salina.

A sensibilização e desafio com subtilisina induziram a produção significativa de $\operatorname{IgE}$ total sérica e os níveis desta imunoglobulina foram ainda maiores na ausência de alum durante a sensibilização à subtilisina (figura 3C). Resultado semelhante foi verificado para a produção de IgG1 específica para a subtilisina (dados não mostrados). A análise dos cortes de tecido pulmonar após coloração com hematoxilina e PAS mostrou uma inflamação peribroncovascular com intenso infiltrado celular apenas no grupo sensibilizado e desafiado com a subtilisina sozinha (figura 3D). Pela coloração dos cortes de pulmão com hematoxilina e eosina (H/E) e observação das lâminas em maior aumento num microscópio óptico, nota-se que este infiltrado é composto, majoritariamente, de células eosinofílicas (dados não mostrados). Ainda pela histologia pulmonar, verificamos a presença de células epiteliais brônquicas intensamente coradas em rosa no grupo subtilisina, o que indica a alta produção de muco por essas células (figura 3D, meio). Essas características clássicas da resposta alérgica, infiltrado celular e muco, foram verificadas ao longo de toda a extensão do lobo analisado e em diversos bronquíolos (e ao redor de vasos no caso do infiltrado celular) de animais que receberam subtilisina, indicando que este fenômeno ocorre de maneira difusa no tecido (dados 
não mostrados). Em resumo, esses resultados mostram que a subtilisina foi bastante eficiente na indução de inflamação pulmonar eosinofílica, secreção de IgE e produção de muco. Ainda, que a adição do adjuvante alum durante a fase de sensibilização previne o potencial alergênico da subtilisina. Vale comentar que não houve diferença na resposta alérgica à subtilisina quando utilizamos camundongos machos e analisamos os mesmos parâmetros (dados não mostrados), comparados às fêmeas. 
Figura 3- Inflamação alérgica das vias aéreas induzida por subtilisina ou papaína.
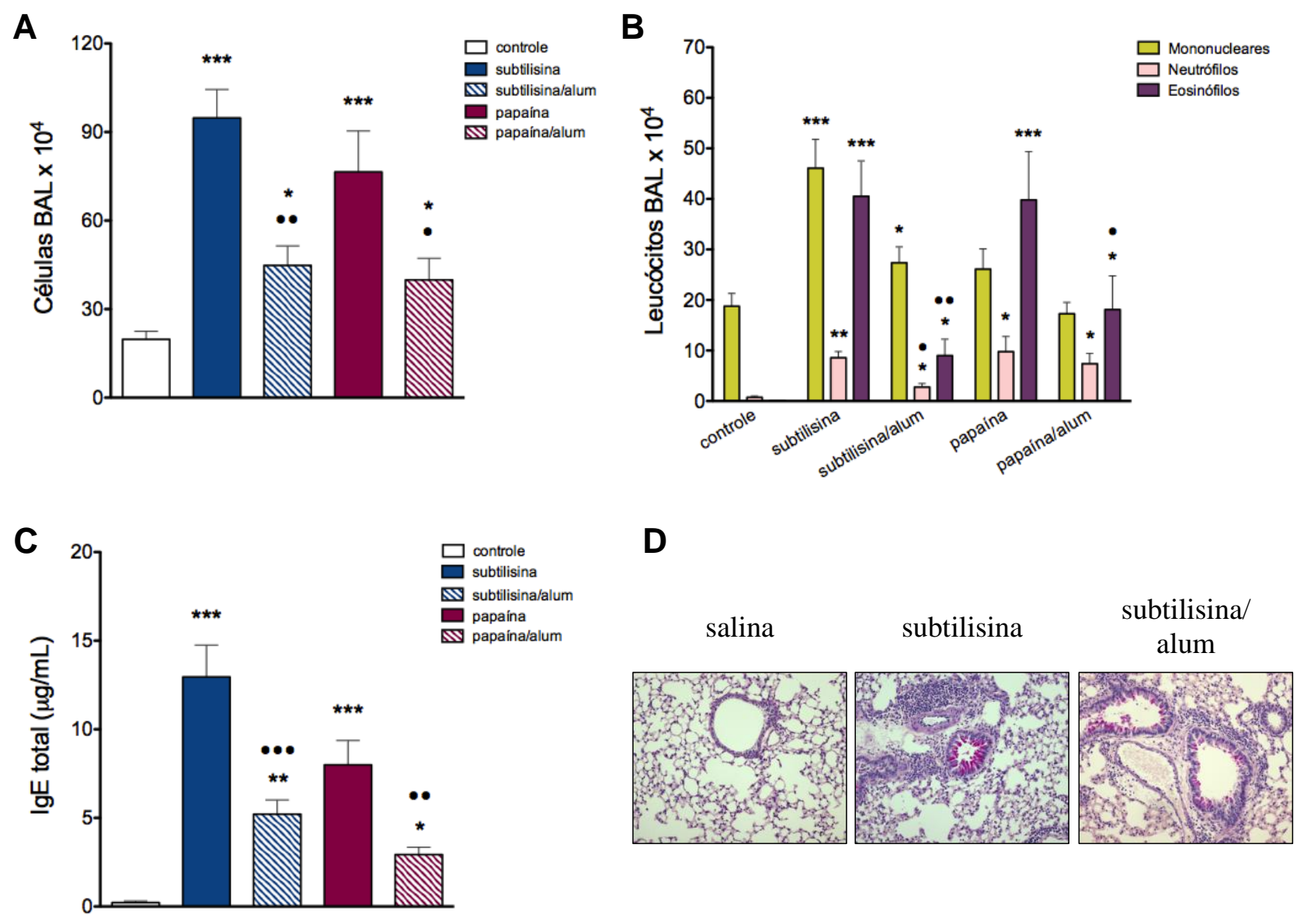

Para o estabelecimento do modelo experimental de asma ocupacional, camundongos C57BL/6 foram sensibilizados com protease por via subcutânea nos dias 0 e 7 e desafiados por via intranasal nos dias 14 e 21, conforme protocolo 1 descrito na Metodologia. Os grupos controles receberam salina (mostrado nesta figura) ou PBS para comparação com os grupos administrados com $1 \mu \mathrm{g}$ de subtilisina ou $5 \mu \mathrm{g}$ de papaína, respectivamente, e as análises foram realizadas no dia 22. Número total (A) e diferencial (B) de células do lavado broncoalveolar (BAL). Produção sistêmica de IgE total (C). Seções histológicas de tecido pulmonar mostrando a produção de muco e o infiltrado celular (D), em aumento de 200x. Representativo de cinco experimentos independentes $(n=5)$. 
A seguir, analisamos o efeito da subtilisina na função respiratória de animais sensibilizados em resposta à estímulo com broncoconstritor não específico, a metacolina (MCh), ou em resposta ao próprio alérgeno, subtilisina. Como o método de análise da reatividade das vias aéreas não é invasivo, isso nos permitiu determinar a resposta à metacolina e à subtilisina nos mesmos grupos de animais, em diferentes dias. Portanto, como já estabelecido em nosso grupo, a resposta à metacolina foi avaliada no dia 15 do protocolo 1 , $24 \mathrm{~h}$ após o primeiro desafio antigênico, e a resposta pulmonar específica ao alérgeno, denominada resposta de fase tardia (late-phase response), no dia 22 logo após o segundo desafio. A análise do padrão respiratório após o primeiro desafio mostrou que todos os grupos apresentam valores de penh (pausa respiratória) semelhantes e menores que 1 na ausência do broncoconstritor. Os grupos sensibilizados com enzima sem adjuvante apresentaram maior aumento do valor de penh em resposta a doses crescentes de metacolina quando comparados aos que receberam alum e ao grupo controle (figura 4A, esquerda), caracterizando um quadro semelhante à hiper-reatividade brônquica desenvolvida em indivíduos com asma (PAWANKAR; CANONICA, 2011). Os mesmos dados são mostrados como área sob a curva (AUC) dos valores de penh (figura 4A, direita). Surpreendentemente, a exposição à subtilisina também foi capaz de induzir a resposta de fase tardia das vias aéreas, em animais sensibilizados. Na figura 4B, verificamos que houve o aumento dos valores penh em resposta à administração i.n. com subtilisina, sem o efeito do bronconstritor metacolina. Portanto, esse protocolo de indução de resposta alérgica à subtilisina é eficiente em promover a reatividade das vias aéreas de maneira específica ao alérgeno ou estimulada por um broncoconstritor. Novamente, verificamos que a sensibilização com alum não induziu uma resposta tão intensa à subtilisina. 
Figura 4- Efeito da subtilisina na função respiratória.

A

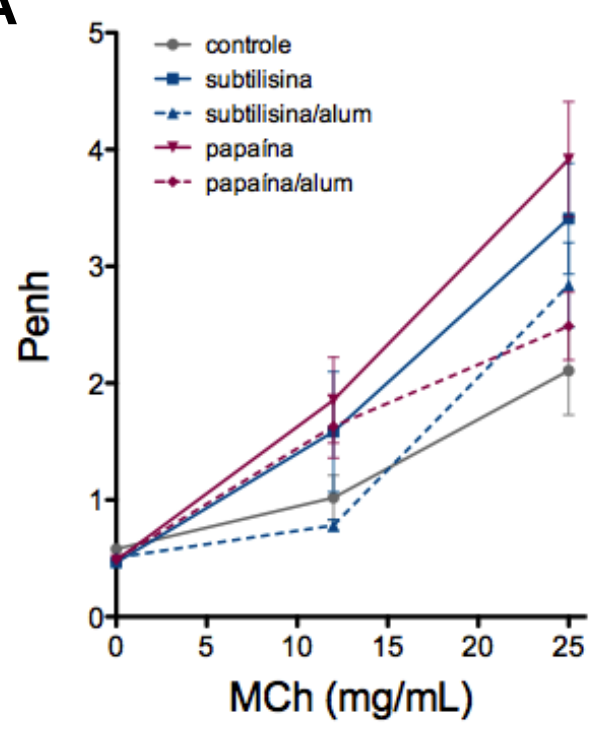

B

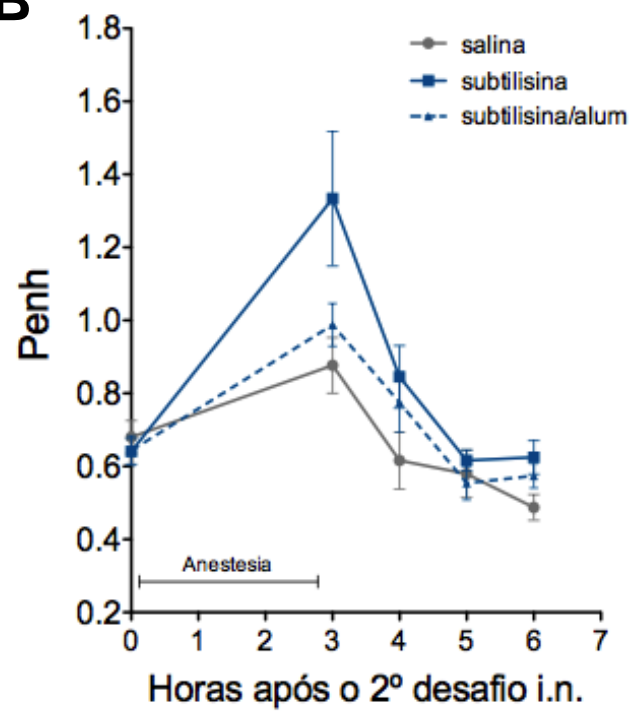

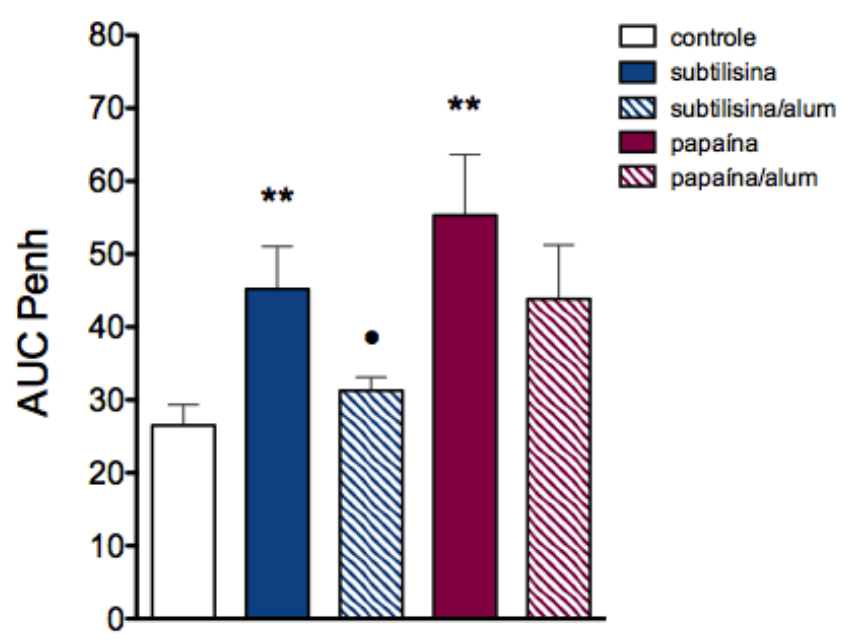

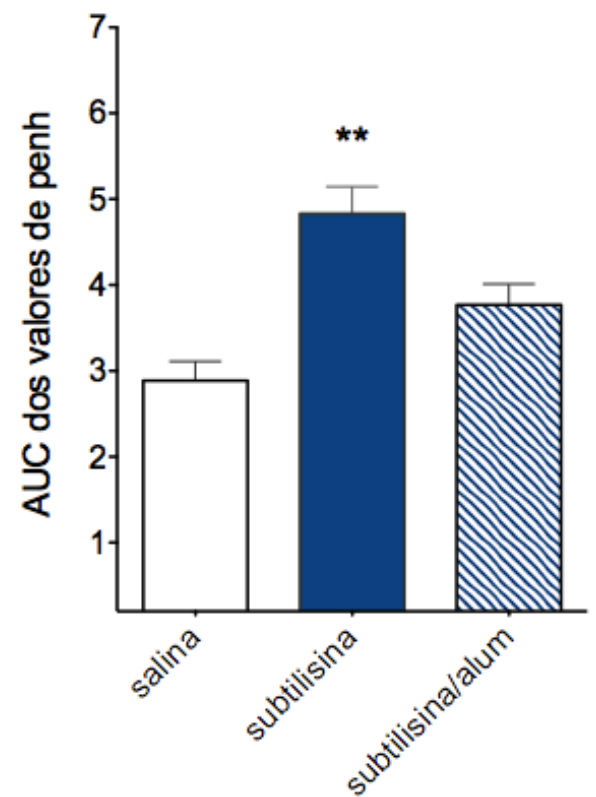

Animais C57BL/6 foram sensibilizados com protease por via subcutânea nos dias 0 e 7 e desafiados por via intranasal nos dias 14 e 21, conforme protocolo 1. Os grupos controles receberam salina (mostrado nesta figura) ou PBS para comparação com os grupos administrados com subtilisina ou papaína, respectivamente. Padrão respiratório representado pelo valor de penh induzido por doses crescentes de metacolina (MCh) $24 \mathrm{~h}$ após o primeiro desafio, dia 15 do protocolo 1 (A, esquerda). Os mesmos dados são mostrados como área sob a curva (AUC) dos valores de penh (A, direita). A resposta tardia das vias aéreas à subtilisina foi analisada por $4 \mathrm{~h}$ a partir da terceira hora após o efeito da anestesia do segundo desafio, dia 21 do protocolo 1 (B, esquerda). Os mesmos dados são mostrados como área sob a curva (AUC) dos valores de penh ( $\mathbf{B}$, direita). Representativo de três experimentos independentes $(\mathrm{n}=5)$. 
Resultados semelhantes aos descritos até aqui foram obtidos utilizando papaína, uma cisteíno-protease sabidamente implicada em alergia ocupacional em humanos. É interessante notar que mesmo que as proteases apresentem pesos moleculares semelhantes $(M M=23$ e 27 $\mathrm{kDa}$, respectivamente), foi necessário utilizar uma concentração pelo menos 10 vezes maior de papaína para que a resposta alérgica gerada fosse comparável à induzida por subtilisina (figura 3A-C e figura 4). Mesmo de maneira menos eficiente, a papaína também foi capaz de gerar uma inflamação alérgica em animais C57BL/6 e, da mesma forma que a subtilisina, a adição de alum durante a sensibilização à papaína inibiu o desenvolvimento de uma resposta Th2 máxima. Isto sugere que o alum deve apresentar uma atividade inibitória geral sobre as proteases.

Em conjunto, estes resultados demonstram que a subtilisina sozinha é um potente indutor de doença pulmonar alérgica e que a adição de alum na sensibilização à subtilisina previne o estabelecimento de uma resposta Th2 ótima. Ainda, a ação alergênica da subtilisina é mais eficiente que a da papaína. Cabe ressaltar que as doses das enzimas foram estabelecidas em modelo de inflamação pulmonar aguda, no qual animais BALB/c receberam diferentes concentrações de subtilisina ou papaína por via i.n. e o recrutamento de células ao BAL, principalmente neutrófilos, foi avaliado $24 \mathrm{~h}$ depois (dados não mostrados). Utilizamos $20 \mu \mathrm{g}$ de LPS em um grupo de animais como controle positivo. Ainda, o protocolo de indução de resposta alérgica à subtilisina e à papaína também foram estabelecidos em camundongos BALB/c. Apesar de termos obtidos resultados semelhantes aos mostrados nas figuras 3 e $\mathbf{4}$, foi necessário usar uma concentração maior de subtilisina, $10 \mu \mathrm{g}$, e de papaína, $20 \mu \mathrm{g}$, para sensibilizar animais dessa linhagem (dados não mostrados). A única exceção foi em relação à resposta tardia da reatividade brônquica. Ao contrário de animais C57BL/6 (figura 4B), nenhuma das concentrações utilizadas de subtilisina ou papaína foram capazes de induzir o aumento do valor penh em animais BALB/c (dados não mostrados).

A partir da observação de que o alum, adjuvante pró Th2 comumente utilizado, inibiu o estabelecimento de uma resposta Th2 máxima induzida pela subtilisina ou pela papaína, hipotetizamos que este adjuvante poderia interferir na atividade enzimática. De fato, quando diferentes concentrações de suspensão de alum são adicionadas ao ensaio in vitro, a atividade remanescente de ambas as proteases diminui de forma dose-dependente (figura 5A), que sugere que a atividade proteásica deve desempenhar uma função importante na alergenicidade. É interessante notar que a concentração de alum inicial utilizada nesses ensaios de atividade é a mesma usada nos experimentos in vivo $(8,4 \mathrm{mg} / \mathrm{mL})$ e a dose de 50 
$\mu \mathrm{L}$ desta solução, que inibiu mais de $80 \%$ da atividade da subtilisina, representa $25 \%$ da dose utilizada nos camundongos. Portanto, é de se esperar que a sensibilização com esta solução de adjuvante possua grande potencial inibidor na atividade das enzimas in vivo e pode explicar por que a resposta alérgica neste caso foi menos intensa do que na ausência do alum.

\section{Figura 5- Inibição das atividades enzimáticas da subtilisina e papaína por alum ou modificadores específicos.}

A
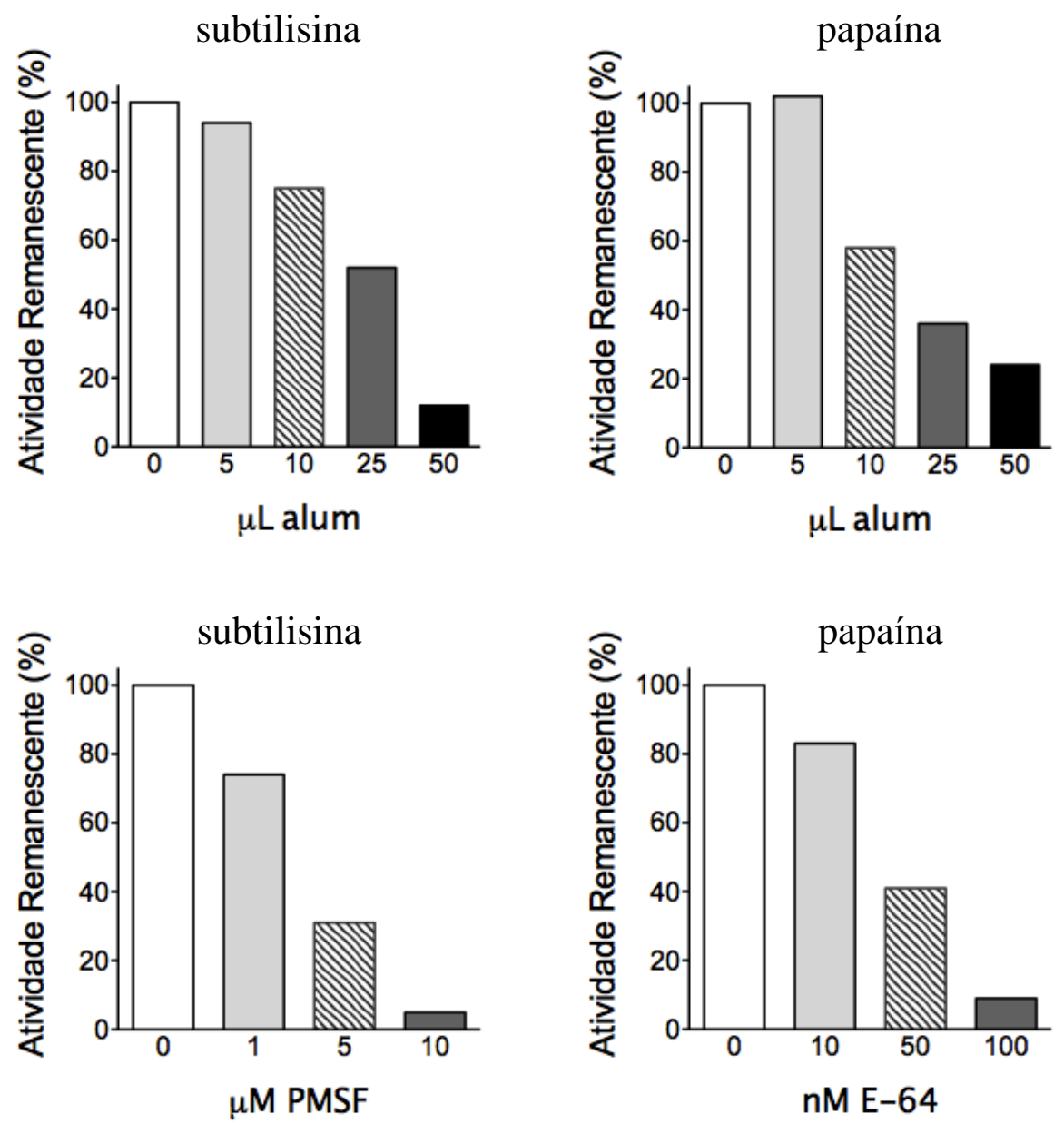

Atividades enzimáticas de amostras frescas de subtilisina $(5 \mu \mathrm{g} / \mathrm{mL})$ (A, esquerda) ou papaína $(25 \mu \mathrm{g} / \mathrm{mL})$ (A, direita) incubadas com doses crescentes de alum (solução inicial a $8,4 \mathrm{mg} / \mathrm{mL}$ ) (A). Os resultados são expressos como atividade remanescente, i.e., a emissão de fluorescência por minuto, que representa a inclinação da reta gerada pela clivagem do substrato. Considerou-se $100 \%$ a atividade apresentada pela protease ativa, livre de alum ou inibidor específico. Os dados foram obtidos a cada $5 \mathrm{~min}$, num total de $60 \mathrm{~min}$. Concentrações crescentes de PMSF diluídas em etanol (B, esquerda) ou de E-64 diluídas em DMSO (B, direita) foram adicionadas (B). Representativo de, pelo menos, cinco experimentos independentes cada um realizado em triplicata. 


\subsection{A atividade enzimática da subtilisina é fundamental no desenvolvimento da inflamação alérgica}

Neste novo ensaio, testamos se o modificador de serino-proteases PMSF seria capaz de inibir a atividade da subtilisina, utilizando concentrações crescentes do inibidor e observando a atividade enzimática remanescente (\%AR). Como grupo controle, utilizamos uma amostra com tampão, substrato e $10 \%$ de EtOH, que foi o solvente utilizado para a diluição do PMSF. Primeiramente, verificamos que a enzima é estável até 35 min de ensaio (regressão linear $\mathrm{R}^{2}=0,9985$ ) (dados não mostrados). Depois, que a adição desta quantidade de EtOH não é capaz de inibir a atividade da subtilisina (grupo não mostrado, mas semelhante ao grupo 0 na figura 5B, esquerda). E, por fim, que o PMSF realmente exerce um efeito inibidor. O PMSF na concentração de $5 \mu \mathrm{M}$ inibiu $73 \%$ da atividade enzimática e a próxima concentração, de $10 \mu \mathrm{M}$, já inibiu quase que completamente sua atividade, mas não foi de $100 \%$ (figura 5B, esquerda). A partir disto, decidimos utilizar a concentração de $10 \mu \mathrm{M}$ de PMSF para experimentos in vivo, pois nesta faixa nos certificamos de que não há inibidor livre, o que poderia ter efeito tóxico. Desse modo, dispomos de um método para determinação da atividade enzimática da subtilisina tecnicamente rápido e de fácil execução. Esta atividade foi verificada antes de cada experimento. Como comparação, também analisamos a cinética de inibição da papaína pelo modificador geral de cisteíno-protease, E-64, e determinamos a concentração ótima de $50 \mathrm{nM}$ deste inibidor para os experimentos in vivo posteriores (figura 5B, direita).

Para determinar a participação da atividade da subtilisina na resposta alérgica, animais C57BL/6 foram sensibilizados com subtilisina na forma ativa ou inativada por PMSF, um modificador de serino proteases, e desafiados com a forma ativa da enzima, baseado no protocolo 1. A sensibilização com a forma inativa da subtilisina foi, claramente, menos eficiente que a forma ativa em recrutar células inflamatórias ao espaço broncoalveolar, principalmente eosinófilos (figura 6A e B). A análise por citometria de fluxo confirmou que a sensibilização com a forma inativada da enzima preveniu a migração às vias aéreas (BAL e pulmão) de eosinófilos (células granulosas que expressam Siglec-F, mas não moléculas do MHC II) e neutrófilos (granulócitos que expressam altos níveis de Gr1, ou Ly6G, mas não moléculas do MHC II) (figura 6C). Interessante notar que a frequência de células inflamatórias recrutadas, ou ao menos dos granulócitos, é maior no espaço alveolar (BAL) do que no pulmão. Ainda, a atividade de protease da subtilisina foi essencial para a produção de anticorpos séricos totais $\mathrm{IgE}$, anticorpos séricos $\mathrm{IgG}$ 1 específicos à subtilisina e para secreção 
de muco por células epiteliais brônquicas (figura 6D, E e F, respectivamente). Em conjunto, estes resultados indicam que as respostas alérgicas à subtilisina são dependentes de sua atividade proteásica específica durante a fase da sensibilização. Consistente com trabalhos anteriores (Baur \& Fruhmann, 1979; Sokol et al., 2008), a atividade de cisteíno-protease da papaína também foi essencial para o desenvolvimento de inflamação eosinofílica pulmonar e produção de anticorpos (figura 6A, B e D). 
Figura 6- A atividade de serino protease da subtilisina é essencial para o desenvolvimento da resposta alérgica.

A

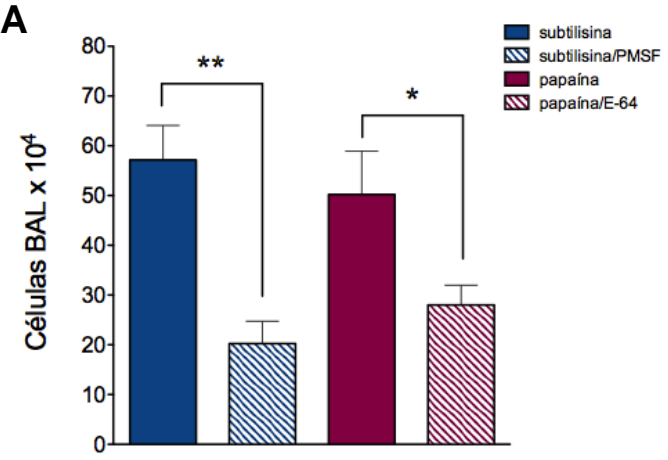

C

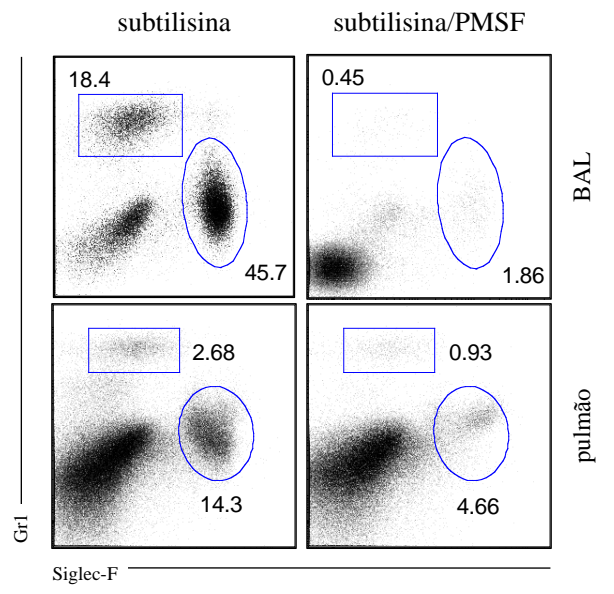

B

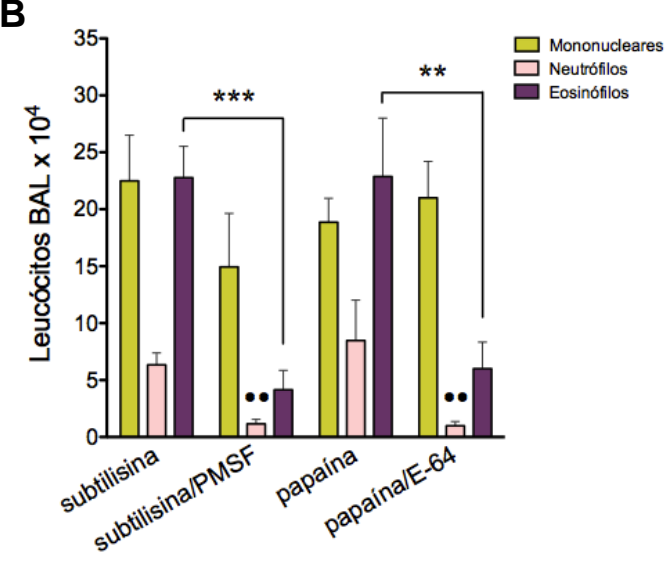

D

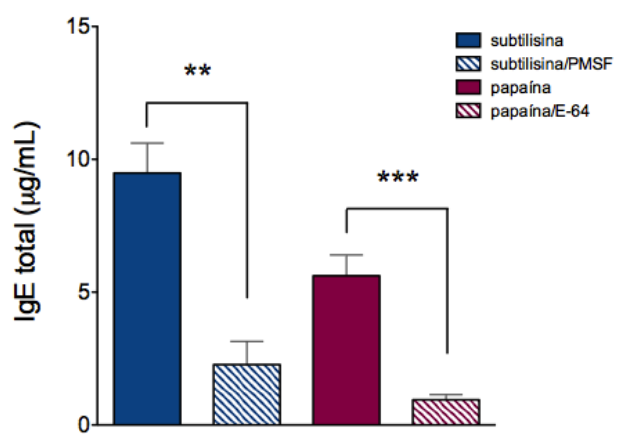

$\mathbf{F}$

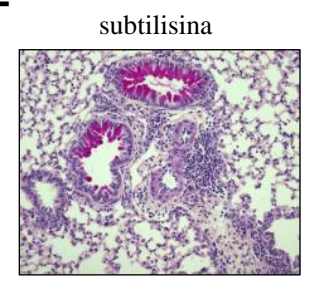

subtilisina/PMSF

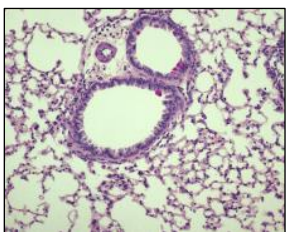

$\mathbf{E}$

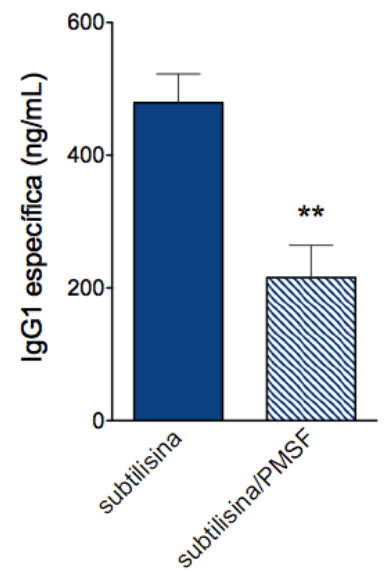

Camundongos C57BL/6 foram sensibilizados por via subcutânea com protease na forma ativa ou inativada por inibidor, PMSF $10 \mu \mathrm{M}$ para a subtilisina e E-64 $50 \mathrm{nM}$, nos dias 0 e 7 e desafiados por via intranasal nos dias 14 e $21 \mathrm{com}$ a forma ativa da enzima (baseado no protocolo 1). Número total $(\mathbf{A})$ e diferencial $(\mathbf{B})$ de células do BAL. Análise de células $\mathrm{CD}^{+} 5^{+} \mathrm{MHCII}^{-}$do BAL (acima) ou pulmão (abaixo) por citometria de fluxo (C). Foram adquiridos 500.000 eventos totais para análise da expressão dos marcadores de superfície em cada uma das amostras individuais. $\mathrm{O}$ resultado mostrado em $\mathbf{C}$ representa uma das amostras verificadas de cada um dos grupos. Produção sistêmica de $\operatorname{IgE}$ total $(\mathbf{D})$ e $\operatorname{IgG} 1$ específica à subtilisina (E). Seções histológicas de tecido pulmonar corados por PAS e hematoxilina mostrando a produção de muco (em rosa) e o infiltrado celular na região peribroncovascular (F), em aumento de 200x. Representativo de três experimentos independentes $(\mathrm{n}=5)$. 
A análise do perfil de citocinas produzidas por linfócitos $\mathrm{T}$ (células $\mathrm{CD} 3^{+} \mathrm{CD} 4^{+}$) pulmonares mostrou que a sensibilização com subtilisina ativa, mas não inativada com PMSF, promoveu a produção de IL-4, IL-5 e IL-2, mas não de IFN- $\gamma$ (figura 7A). Essa produção de citocinas inflamatórias ocorreu tanto por uma ativação policlonal (estímulo com PMA e ionomicina) quanto específica (estímulo com subtilisina) das células pulmonares. Também verificamos uma frequência significativa de linfócitos T produtores IL-17A no pulmão de animais sensibilizados com subtilisina ativa, tanto com estímulo específico quanto policlonal. Esta frequência foi semelhante em animais sensibilizados com a forma inativa da enzima, cujas células pulmonares foram re-estimuladas policlonalmente in vitro. Mas quando esse linfócitos foram estimulados especificamente com a subtilisina, esta produção de IL-17A foi menor (figura 7A). De maneira semelhante, a sensibilização com subtilisina inativa preveniu a indução do fator de transcrição pró-Th2, Gata-3, induzido em linfócitos T pulmonares de animais sensibilizados com subtilisina ativa (figura 7B). Ainda, a enzima sem atividade não induziu o aumento da expressão dos fatores de transcrição pró Th1, T-bet, pró-Th17, Rorc, nem regulador, Foxp3, sugerindo que não houve o fenômeno de desvio imunológico e polarização da resposta para outro fenótipo inflamatório (figura 7B). Estes resultados sugerem, em conjunto, que a subtilisina promoveu a resposta Th2 específica de maneira dependente de sua atividade enzimática. 
Figura 7- Perfil de citocinas e fatores de transcrição em linfócitos $\mathbf{T}$ pulmonares.

A
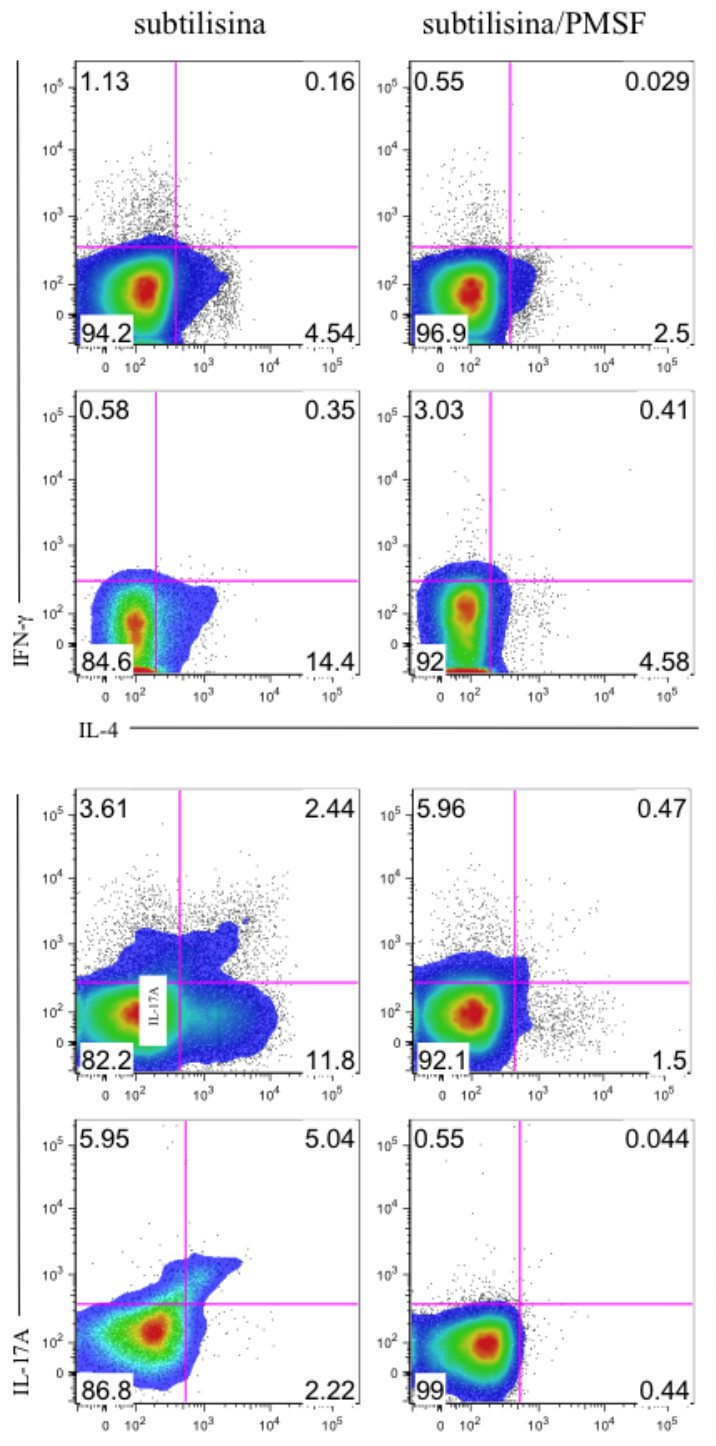

IL-

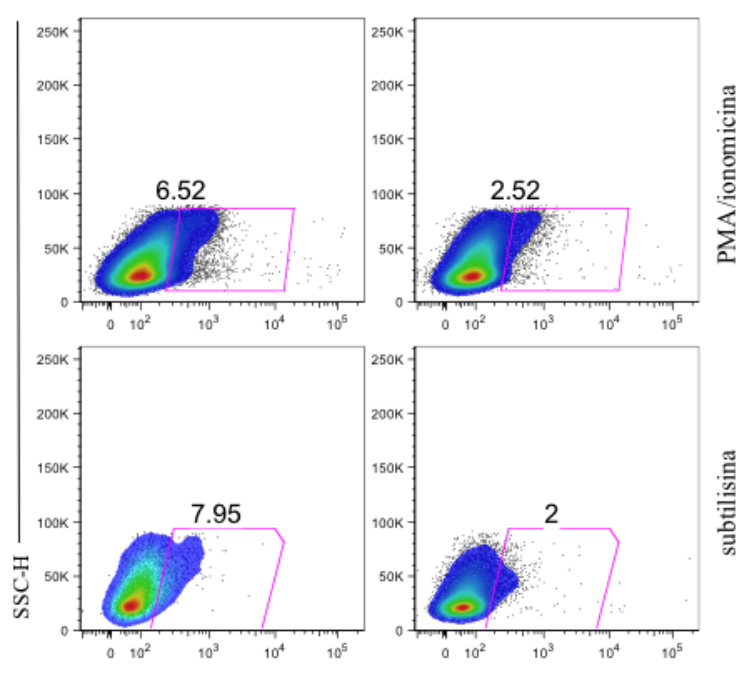

B
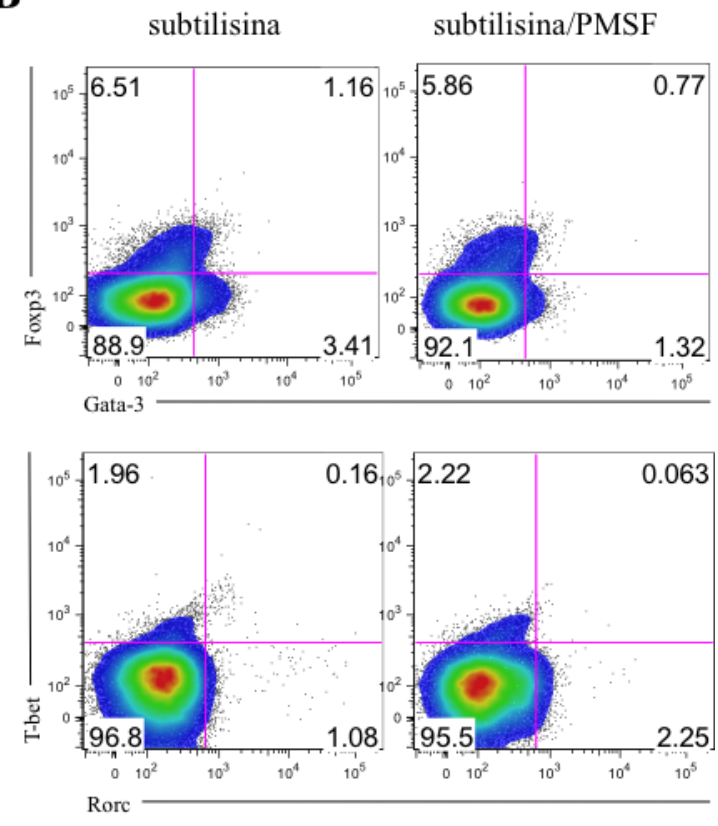

Camundongos C57BL/6 foram sensibilizados por via subcutânea com subtilisina ativa ou inativada por PMSF (10 $\mu \mathrm{M})$ nos dias 0 e 7 e desafiados por via intranasal nos dias 14 e 21 com a forma ativa da enzima (protocolo 1). No dia 22, os pulmões foram coletados após perfusão com PBS e digeridos com colagenase IV e Dnase I. Para análise da produção de citocinas, as células pulmonares totais foram estimuladas com PMA e ionomicina e incubadas por $5 \mathrm{~h}$ (no gráfico: PMA/ionomicina, acima) ou com subtilisina ativa a $1 \mu \mathrm{g} / \mathrm{mL}$ e incubadas por $18 \mathrm{~h}$ (subtilisina, abaixo), ambas a $37^{\circ} \mathrm{C}$ (A). As células foram incubadas com marcadores de superfície para linfócitos $\mathrm{T}$ e para as citocinas citadas e depois foram analisadas por citometria de fluxo. Gráficos de FACS mostram as frequências de células pulmonares viáveis $\mathrm{CD}^{+} \mathrm{CD}^{+}$(A). A expressão de fatores de transcrição por células $\mathrm{CD} 3^{+} \mathrm{CD} 4^{+}$também foi verificada por citometria de fluxo após estimulação de células pulmonares totais com PMA e ionomicina e incubação por $5 \mathrm{~h}$ a $37^{\circ} \mathrm{C}(\mathbf{B})$. Representativo de dois experimentos independentes $(n=5)$. 
A seguir, verificamos em que etapas da resposta alérgica a atividade da subtilisina seria importante, se seria somente durante a sensibilização s.c. para o desenvolvimento da inflamação, como descrito há pouco (figura 6), ou também nos desafios intranasais para o estabelecimento e direcionamento da resposta às vias aéreas. Como o PMSF solubilizado em DMSO representa um composto de alta toxicidade optamos por utilizar o método da inativação da atividade enzimática por calor para exposição da subtilisina pela mucosa pulmonar. De maneira semelhante à utilização da subtilisina com PMSF, a sensibilização s.c. de animais C57BL/6 com subtilisina inativada termicamente e desafio i.n. com a enzima ativa também preveniu o desenvolvimento da inflamação alérgica pulmonar (dados não mostrados, mas utilizamos os mesmos parâmetros de análise mostrados na figura 3 para comparação). No entanto, quando animais receberam a forma inativada da subtilisina apenas nos desafios i.n. - portanto, sensibilizados com a forma ativa pela via s.c.- a resposta alérgica foi idêntica à verificada anteriormente com o uso da protease ativa em todas as etapas (dados não mostrados). Estes resultados sugerem que a atividade enzimática é importante apenas na fase de início e desenvolvimento da resposta alérgica à subtilisina, mas não após o estabelecimento da inflamação e geração da resposta adaptativa Th2.

\subsection{A resposta alérgica à subtilisina é dependente da molécula adaptadora MyD88, do receptor de IL-1 e do receptor PAR-2}

Sinais inatos tem sido reconhecidos como fundamentais na iniciação da sensibilização alérgica (PALM et al., 2013). A molécula MyD88 é a proteína adaptadora central na sinalização pelos receptores do tipo Toll (TLRs) e receptores das citocinas da família da IL-1, como a própria IL-1, IL-18 e IL-33 (DINARELLO, 2009), e é responsável pelo começo de algumas respostas mediadas por linfócitos Th2 ou ativação de mastócitos (KROEGER; SULLIVAN; LOCKSLEY, 2009). Além da molécula MyD88, alguns grupos de pesquisa relataram a importante participação do receptor do tipo toll 4 (TLR4) na indução da inflamação alérgica induzida, por exemplo, por aeroalérgenos presentes em ácaros da poeira doméstica (HAMMAD et al., 2009) ou ainda pelo níquel, responsável pela maioria dos casos de hipersensibilidade de contato em humanos (SCHMIDT et al., 2010). Por isto, determinamos a função das moléculas TLR4 e MyD88 na resposta Th2 induzida pela subtilisina.

Pelo mesmo protocolo de sensibilização e desafio utilizados até aqui (protocolo 1), verificamos que animais deficientes de TLR4 exibem uma resposta alérgica à subtilisina bastante semelhante aos animais selvagens (wild type, WT) em termos de inflamação celular 
nas vias aéreas (eosinofilia), produção de anticorpos e frequência de linfócitos $\mathrm{CD} 3^{+} \mathrm{CD} 4^{+}$ produtores de IL-5 no pulmão (figura 8A-D). Ainda, a presença das citocinas IL-4, IL-6, IL10 e TNF- $\alpha$ quantificadas no BAL de animais TLR4 $/$ também foi semelhante comparado ao BAL de animais WT (figura 8E).

Ao contrário, animais MyD88\% sensibilizados com subtilisina apresentaram uma resposta inflamatória bastante reduzida, ou seja, menor recrutamento de células às vias aéreas, menor produção de anticorpos séricos $\operatorname{IgE}$ e de IL-5 por linfócitos $\mathrm{CD} 3{ }^{+} \mathrm{CD} 4^{+}$no pulmão, e também menos citocinas no BAL (figura 8A-D), quando comparados aos animais alérgicos WT. É relevante evidenciar que, além da frequência reduzida de linfócitos Th2 no pulmão de animais deficientes de MyD88, o número de células hematopoiéticas (CD45 $)$ e, portanto, de linfócitos $\mathrm{T}$ no tecido pulmonar também foi bem menor (aproximadamente 5 vezes) comparado a animais WT alérgicos (dados não mostrados). Não detectamos níveis significativos de IL-2, IL-17A ou IFN- $\gamma$ no BAL de nenhum dos grupos analisados e verificamos uma intensa produção de muco em animais WT e TLR4\%, mas não nos MyD88\% (dados não mostrados). Portanto, a resposta alérgica à subtilisina parece ser dependente da proteína adaptadora MyD88, mas não do receptor TLR4. 
Figura 8- A resposta alérgica induzida pela subtilisina é dependente de MyD88, mas não de TLR4.

A

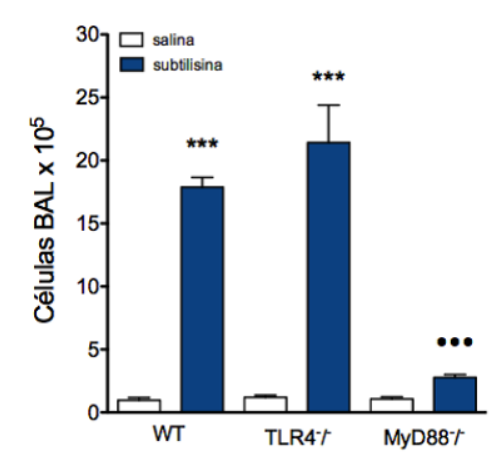

B

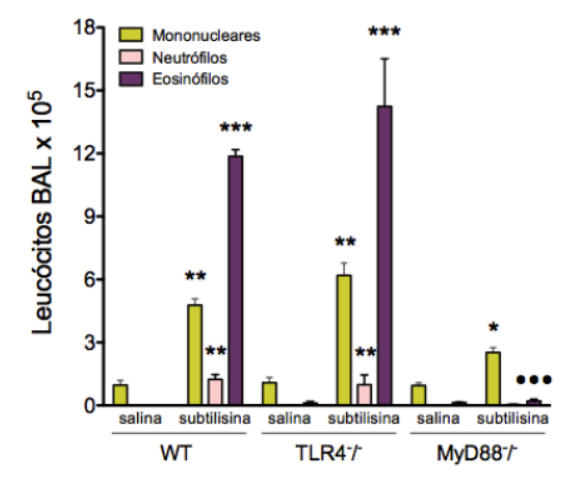

C

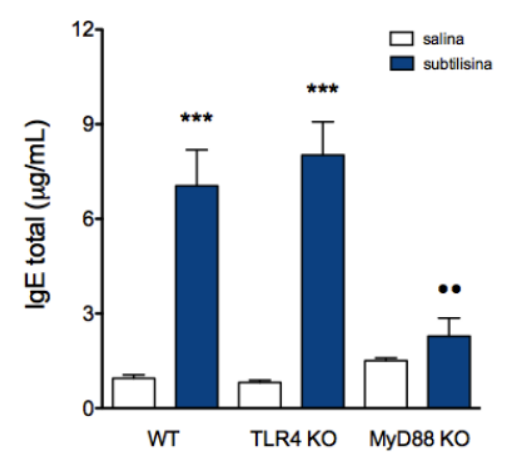

D
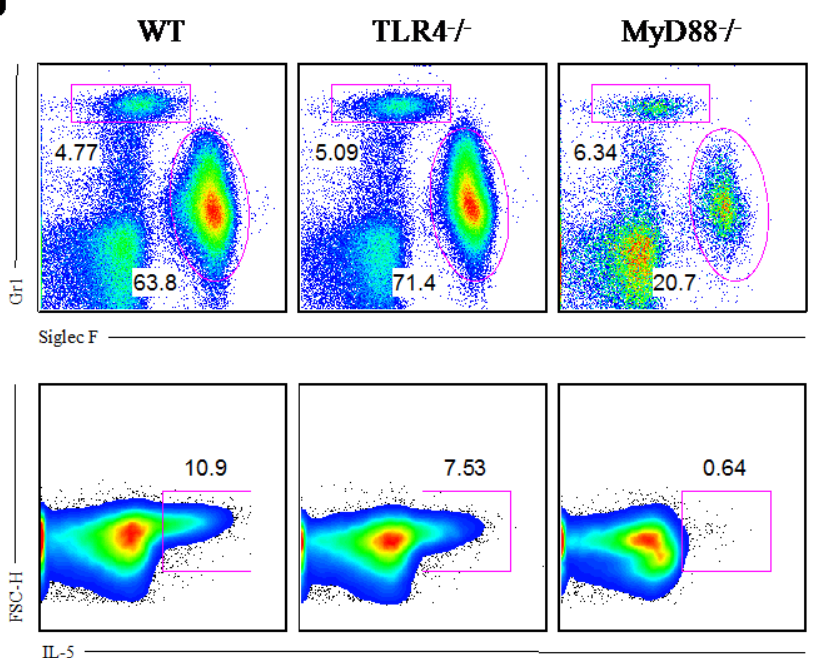

E
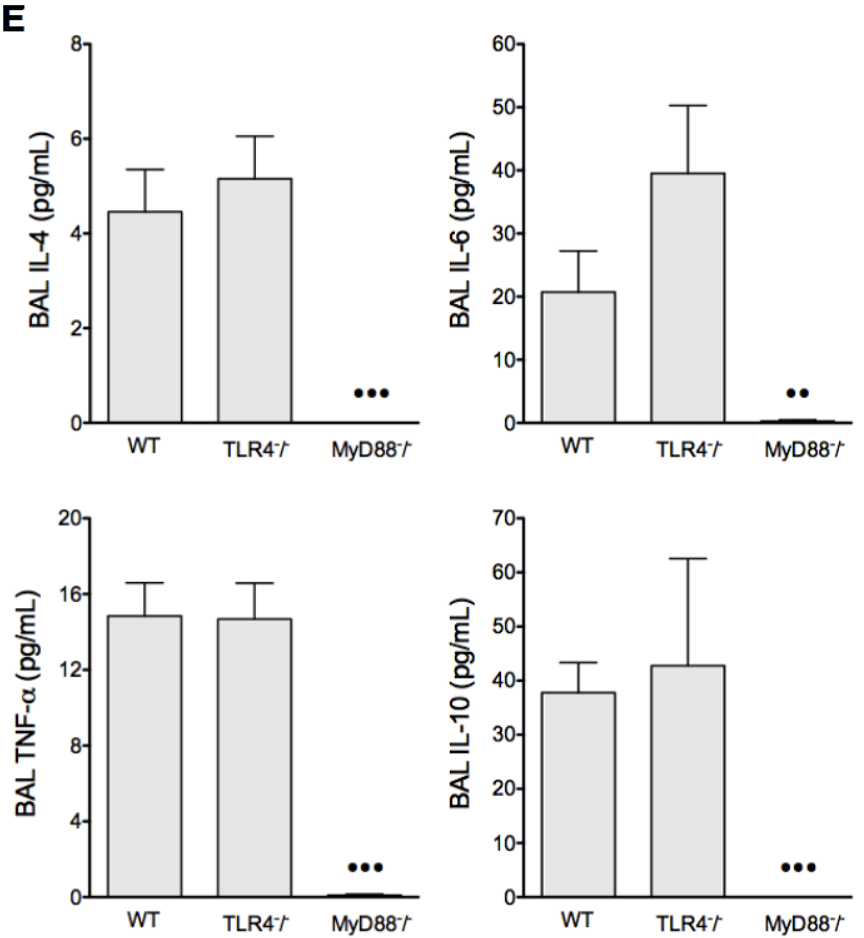

Camundongos C57BL/6 WT, TLR4\% ou MyD88\% foram sensibilizados por via subcutânea com subtilisina nos dias 0 e 7 e desafiados por via intranasal nos dias 14 e 21 . O grupo controle recebeu somente salina e as análises foram realizadas no dia 22 , seguindo o protocolo 1. Número total (A) e diferencial (B) de células do BAL. Produção sistêmica de IgE total $(\mathbf{C})$. Análise de células $\mathrm{CD} 45^{+} \mathrm{MHCII}^{-}$do $\mathrm{BAL}$ (acima) ou $\mathrm{CD}^{4} 5^{+} \mathrm{CD} 3^{+} \mathrm{CD} 4^{+}$do pulmão (abaixo) por citometria de fluxo de animais administrados com subtilisina (D). Foram adquiridos $0,5 \times 10^{6}$ e $1,0 \times 10^{6}$ eventos totais por amostra para a análise celular do BAL e do pulmão, respectivamente. Citocinas presentes no BAL de animais sensibilizados e desafiados com subtilisina, analisadas por CBA (E). Representativo de três experimentos independentes $(\mathrm{n}=5)$. 
Além dos TLRs, os membros da prototípica família da IL-1 também são conhecidos sinalizadores da via que utiliza o adaptador MyD88. Há um crescente interesse na participação da IL-1 na promoção de respostas alérgicas desde que tal relação foi inferida em modelo de asma murina induzida por extrato de ácaro, assim como estudos de polimorfismos genéticos em células humanas (RAMADAS et al., 2006). Dessa forma e após a observação da importante participação da molécula MyD88, decidimos investigar a função da sinalização via IL-1R na inflamação alérgica pulmonar induzida por subtilisina.

Para isto, animais WT ou deficientes no receptor de IL-1 ( $\alpha$ e $\beta$ ), IL-1R ${ }^{-}$, foram sensibilizados com subtilisina ativa nos dias 0 e 7 por via s.c. e desafiados com a enzima por via i.n. nos dia 14 e 21, conforme protocolo 1. A figura 9A mostrou que o recrutamento de células totais ao BAL de animais deficientes de IL-1R foi aproximadamente 4 vezes menor comparado ao influxo celular verificado em animais WT (média aritmética aproximada de $16,3 \times 10^{5}$ vs 4,4 $\times 10^{5}$ células, respectivamente) em resposta à subtilisina. A análise morfológica das células presentes no BAL mostrou uma diminuição significativa de células mononucleares e eosinófilos em animais $\mathrm{IL}_{-1} \mathrm{R}^{\top}$ ' sensibilizados e desafiados com subtilisina em relação aos animais alérgicos WT (figura 9B). Igualmente, na análise das células no BAL e pulmão por citometria de fluxo verificou-se uma menor frequência de eosinófilos (MHCII Siglec $\mathrm{F}^{+}$), mas, surpreendentemente, maior frequência de neutrófilos $\left(\mathrm{MHCII}^{-} \mathrm{Gr}^{+}\right.$) em

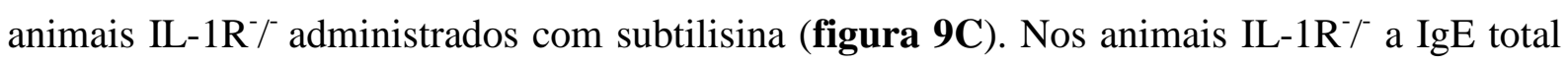
sérica também foi bastante reduzida em comparação aos animais WT em resposta à subtilisina, de aproximadamente 30 vezes $(0,14 v s 4,3 \mu \mathrm{g} / \mathrm{mL}$, respectivamente) (figura 9D). Por fim, a frequência de linfócitos $\mathrm{T} \mathrm{CD}^{+} \mathrm{CD}^{+}$produtores de IL-4 e IL-5, estimulados com PMA/ionomicina ou não, foi menor em animais deficientes de IL-1R administrados com subtilisina em relação aos WT alérgicos (figura 9E). Em conjunto, esses dados indicam a participação essencial da sinalização via IL-1R no desenvolvimento de inflamação alérgica pulmonar induzida pela subtilisina. Será interessante determinar qual das citocinas que sinaliza via este receptor é a principal responsável por este efeito, se seria a IL-1 $\alpha$ ou IL-1 $\beta$, mas voltaremos a discutir esta questão mais adiante. 
Figura 9- A resposta alérgica induzida por subtilisina é dependente do receptor de IL-1.
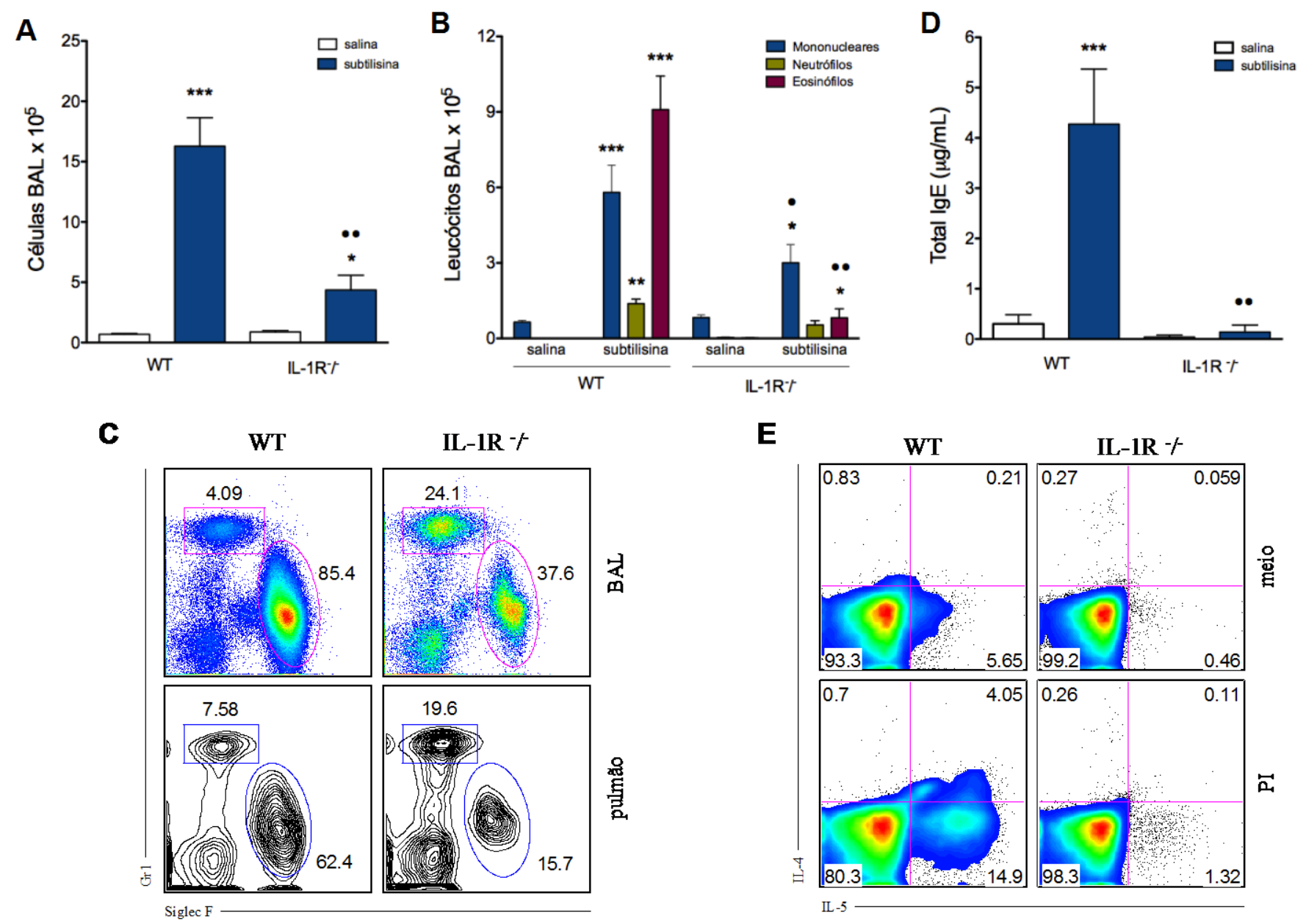

Animais C57BL/6 ou IL-1R// foram administrados com subtilisina pelas via s.c. nos dias 0 e 7 e desafiados por via i.n. nos dias 14 e 21 e as as análises realizadas no dia 22 , como descrito no protocolo 1. Número total (A) e diferencial (B) de células presentes no BAL. Análise por citometria de fluxo de células $\mathrm{CD} 45^{+} \mathrm{MHCII}^{-}$do BAL ou pulmão de animais que receberam subtilisina (C). Quantificação de IgE total sérica por ELISA (D). Frequência de células pulmonares $\mathrm{CD} 45^{+} \mathrm{CD}^{+} \mathrm{CD}^{+}$incubadas com meio de cultura RPMI 1640 (E, acima) e estimuladas com PMA/ionomicina por $12 \mathrm{~h}$ (E, abaixo). Foram adquiridos $0,5 \times 10^{6}$ e $1,0 \times 10^{6}$ eventos totais em $\mathbf{C}$ e $\mathbf{D}$, respectivamente. $\mathrm{n}=5$ animais por grupo. 
Nos vertebrados a atividade proteásica só pode ser reconhecida diretamente de uma única maneira, pelos sensores moleculares acoplados à proteína G, os PARs (proteaseactivated receptors) (SHPACOVITCH et al., 2007a). Como o PAR-2 já foi associado à resposta alérgica induzida por proteases (PAGE; STRUNK; HERSHENSON, 2003; SUN et al., 2001) resolvemos investigar se a presença do PAR-2 influencia a inflamação nas vias aéreas induzida pela subtilisina.

Para isto, animais deficientes de PAR-2 foram sensibilizados pela via s.c. e desafiados por via i.n. de acordo com o protocolo 1, e a resposta foi comparada à desenvolvida por animais WT quando sensibilizados e desafiados da mesma maneira. Em resposta à administração de subtilisina animais deficientes de PAR-2 mostraram um recrutamento reduzido de eosinófilos e neutrófilos às vias aéreas (figura 10A). A produção de IgE total sérica em animais PAR-2-/- sensibilizados com subtilisina também foi bem menor em relação aos animais WT (figura 10B). Ainda, a frequência e número de linfócitos $\mathrm{T}$ convencionais $\left(\mathrm{CD}^{+} \mathrm{CD}^{+}\right)$e de células linfóide inatas (ILC: $\mathrm{CD}^{-}$Thy-1.2 $2^{+}$) produtoras de IL-5 e IL-13 em resposta à subtilisina estavam diminuídos nos animais deficientes de PAR-2 (figuras 10C e D, respectivamente). Em conjunto, esses dados sugerem que a subtilisina promove inflamação alérgica pulmonar via sinalização por PAR-2. 
Figura 10- A resposta alérgica induzida pela subtilisina é dependente da expressão do PAR-2.

A

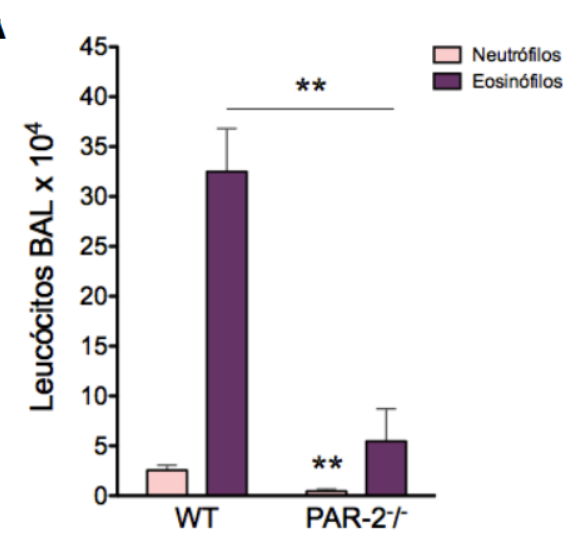

B

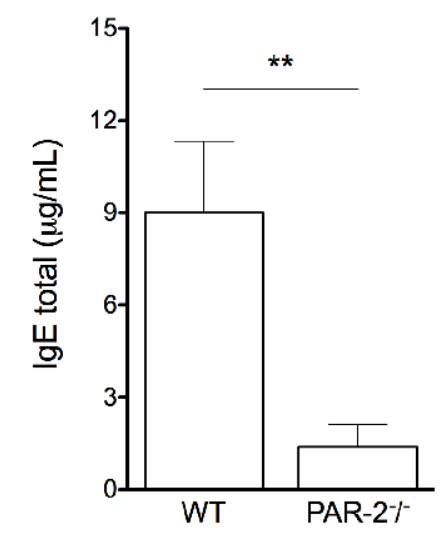

C

WT

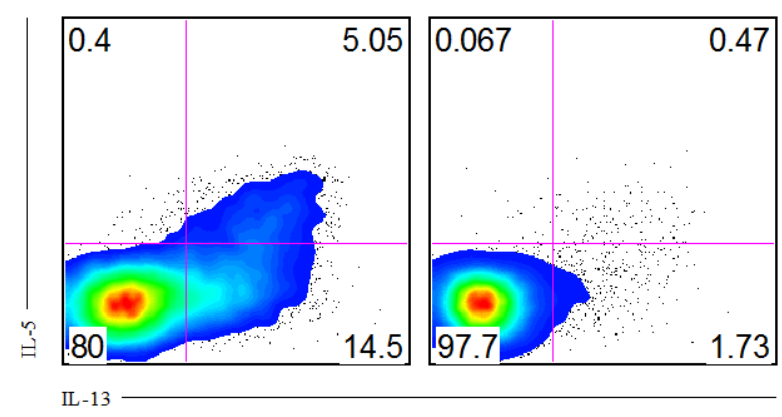

D

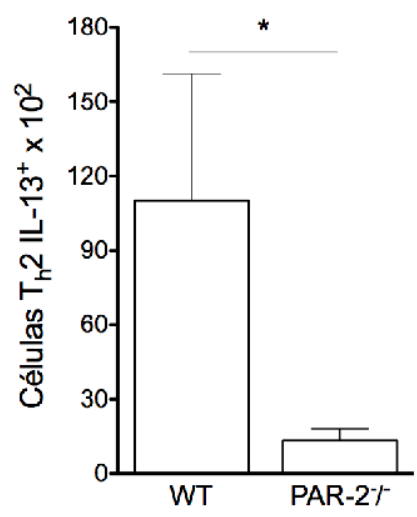

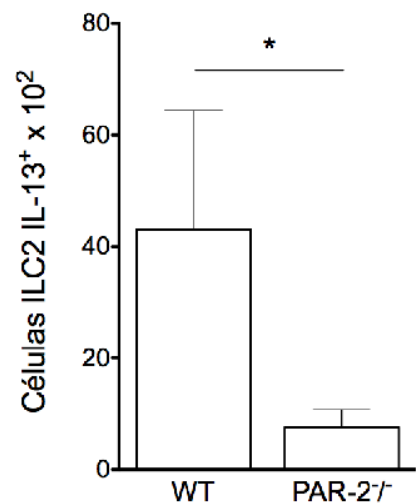

Camundongos C57BL/6 WT ou PAR-2\% foram sensibilizados por via subcutânea com subtilisina nos dias 0 e 7 e desafiados por via intranasal nos dias 14 e 21. Granulócitos presentes no BAL de animais administrados com subtilisina (A). Produção sistêmica de $\operatorname{IgE}$ total (B). Frequência de células $\mathrm{CD} 45^{+} \mathrm{CD}^{+}$produtoras de IL-5 e/ou IL-13 analisadas por citometria de fluxo do pulmão de animais WT ou PAR-2 $\%$ administrados com subtilisina (C). Foram adquiridos $1,0 \times 10^{6}$ eventos totais. Número de células $\mathrm{CD} 45^{+} \mathrm{CD}^{+}$(esquerda) ou $\mathrm{CD}^{+} 5^{+} \mathrm{CD}^{-}$Thy-1.2 $2^{+}$(direita) produtoras de IL-13 no pulmão de animais administrados com subtilisina, análise por citometria de fluxo (D). Representativo de dois experimentos independentes $(\mathrm{n}=5)$. 


\section{4 Efeito da subtilisina em populações de células imunes inatas}

\subsubsection{Ação da subtilisina em células dendríticas e diferenciação de linfócitos Th2}

O mecanismo celular pelo qual as proteases promovem alergia está, atualmente, em intenso debate. Diversos grupos de pesquisa já propuseram que as células dendríticas (DCs) representam a principal população celular inata responsável pela iniciação da imunidade tipo 2 (ver APÊNDICE B). Por isto, no intuito de investigar a participação destas células na resposta alérgica à subtilisina realizamos ensaios in vitro para verificar, primeiramente, se a enzima ativaria DCs. Assim, DCs derivadas de monócitos humanos foram estimuladas com subtilisina ativa (St), inativada termicamente (iSt) ou LPS (controle positivo) e a expressão de marcadores típicos de ativação foram analisados nessas DCs por citometria de fluxo. A expressão de moléculas co-estimuladoras como HLA-DR (receptor de superfície do MHC de classe II em humanos), CD80, CD83 e CD86 estava aumentada em DCs maduras estimuladas com LPS, como representado pela intensidade média de fluorescência (MFI) (figura 11A). Contudo, a estimulação de DCs humanas diretamente pela subtilisina, ativa ou termicamente inativada, não foi capaz de alterar a expressão basal dessas moléculas (figura 11A). A expressão dessas moléculas de ativação em DCs murinas (derivadas da medula óssea de camundongos C57BL/6) também não foi modificada pela estimulação com subtilisina em comparação à ativação por LPS (dados não mostrados). Finalmente, DCs humanas pulsadas com subtilisina, ativa ou não, não induziram a polarização de linfócitos T CD3+ para um padrão Th2, já que não houve a produção de IL-4, citocina tipo 2 prototípica, por estas células (figura 11B). Dessa forma, estes resultados indicam que a subtilisina não consegue ativar DCs diretamente, pelo menos não da maneira clássica. 
Figura 11- A subtilisina não promove ativação de DCs humanas nem polarização de linfócitos $\mathbf{T}$ diretamente.
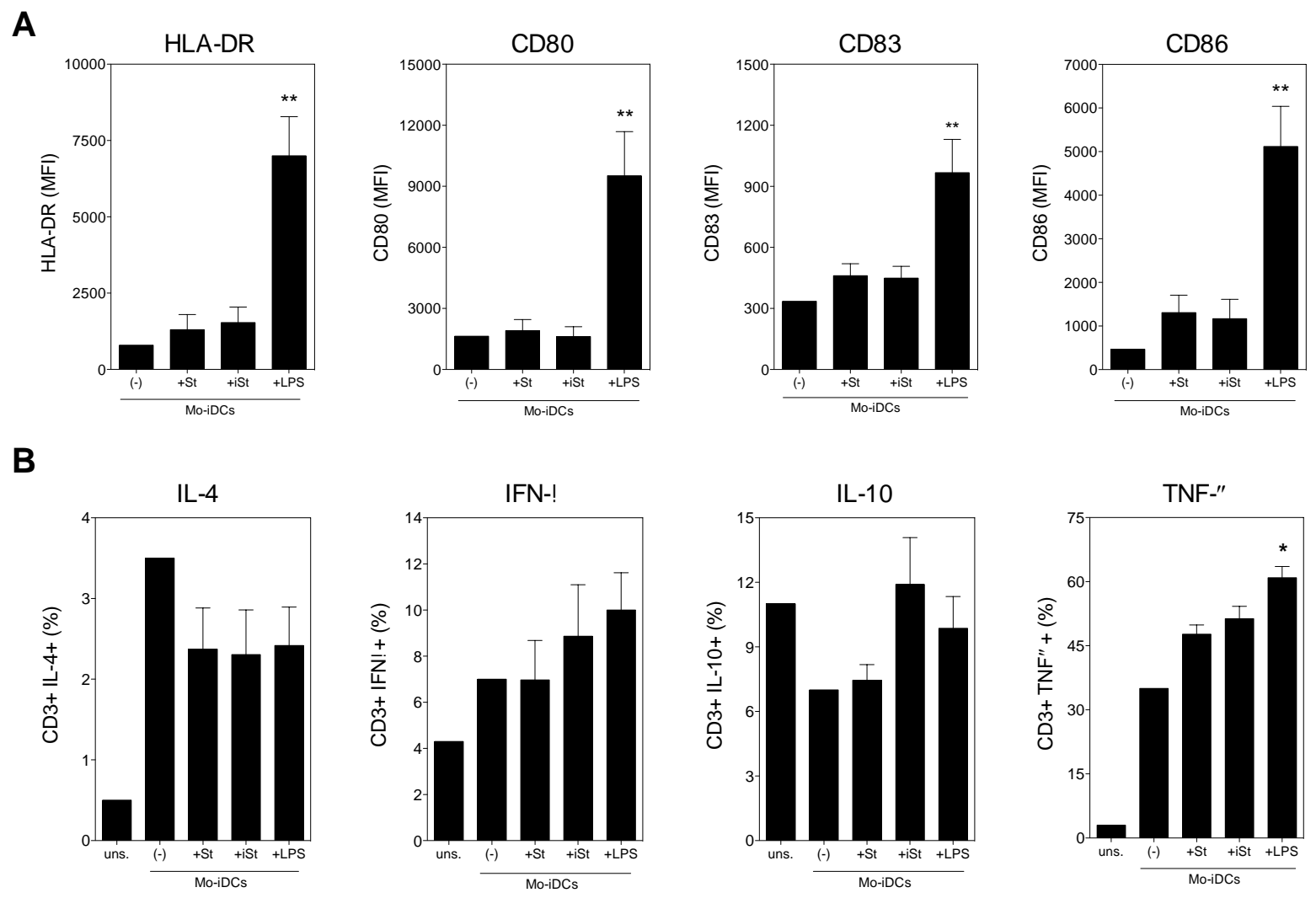

Células dendríticas (iDCs) foram derivadas a partir de monócitos humanos e estimuladas com $1 \mu \mathrm{g} / \mathrm{mL}$ de subtilisina na forma ativa (St), subtilisina termicamente inativada (iSt) ou com $50 \mathrm{ng} / \mathrm{mL}$ LPS por $18 \mathrm{~h}$. O grupo (-) representa o controle negativo, i.e., DCs que receberam apenas meio de cultura. Análise da expressão de superfície de moléculas coestimuladoras por citometria de fluxo, representada pela intensidade média de fluorescência (MFI) em DCs $\mathrm{CD}_{11 c^{+}}(\mathbf{A})$. Produção intracelular de citocinas por linfócitos $\mathrm{T} \mathrm{CD}^{+}$ heterólogos humanos após co-cultura prévia com DCs humanas, pulsadas com os estímulos indicados, e re-estimulados in vitro por $12 \mathrm{~h}$ com PMA e ionomicina (B). Dados representam média \pm erro padrão, de dois experimentos realizados com amostras em triplicatas. 


\subsubsection{Ação da subtilisina em outras células inatas do sistema imune}

Além das DCs, outras células do sistema imune inato poderiam estar envolvidas na indução da inflamação alérgica à subtilisina. Imediatamente, pensamos que uma célula residente tecidual que possui inúmeras funções homeostáticas como é o caso dos macrófagos poderia representar um bom candidato a respondedor direto da atividade enzimática da subtilisina. No entanto, estudos in vitro semelhantes aos realizados com DCs, mas com macrófagos $\mathrm{CD}_{11 b^{+}}$diferenciados a partir de medula óssea de camundongos C57BL/6 mostraram que estas células também não induzem o aumento da expressão das moléculas coestimuladoras MHC II, CD40, CD80 ou CD86 após contato com subtilisina (dados não mostrados).

Outra célula frequentemente implicada em respostas alérgicas é o mastócito e, por isto, também avaliamos o efeito da subtilisina nesta população de duas maneiras: em mastócitos diferenciados a partir da medula óssea de animais C57BL/6 (conhecidos como mBMMCs, do inglês: mouse bone marrow-derived mast cells), utilizando um protocolo já bem estabelecido com IL-3 recombinante (WILLIAMS; GALLI, 2000), e em uma linhagem de mastócitos, a PT18, em colaboração com o laboratório do professor Ruslan Medzhitov e da pesquisadora Eliana Faquim de Lima Mauro do Instituto Butantan (FAQUIM-MAURO; JACYSYN; MACEDO, 2003), respectivamente. A desgranulação e, portanto, ativação de mastócitos foi verificada pela liberação da enzima granular $\beta$-hexaminidase no sobrenadante de cultura, de acordo com o método descrito por Ortega e cols. (ORTEGA; SCHNEIDER; PECHT, 1991). Resultados preliminares utilizando ambas as metodologias apontam para uma desgranulação (portanto, ativação) parcial de mastócitos induzida pela subtilisina na forma ativa (dados obtidos em colaboração, mas não mostrados aqui).

Recentemente, alguns estudos sugeriram que basófilos, granulócitos menos abundantes em mamíferos, são células que realizam função não redundante e contribuem significativamente para o desenvolvimento e progressão de respostas inflamatórias mediadas por citocinas Th2 (SIRACUSA et al., 2013). Recentemente, o grupo de pesquisa do professor Ruslan Medzhitov verificou que a cisteíno protease papaína ativava basófilos e induzia a produção de IL-4 por estes granulócitos (SOKOL et al., 2008) e estabeleceu um método de monitoramento da ativação de basófilos, pela utilização de animais '4get', cujas células que ativam o gene codificador da IL-4 (Il4) podem ser visualizadas pela expressão concomitante da construção bi-cistrônica de GFP (green fluorescent protein), localizada no mesmo locus do Il4 (IL-4- eGFP) (MOHRS et al., 2001). Um ensaio para determinação da produção de IL-4 
por basófilos de execução relativamente fácil foi padronizado por este grupo utilizando basófilos diferenciados da medula óssea de animais 4get. Utilizando este ensaio, verificamos que a subtilisina estimula fracamente a produção de IL-4 pelos basófilos quando comparado à papaína (resposta de 30\% em relação à papaína) e esta produção não foi significativa comparado ao grupo controle (dados parciais não mostrados).

Por fim, também testamos a ação da subtilisina na ativação de células iNKT (invariant natural killer T cells) em colaboração com a pesquisadora Maria Leite de Moraes, do Hospital Necker, Paris-França. Estas células já foram associadas ao início e amplificação de respostas alérgicas em humanos e modelos murinos, principalmente de asma, já que produzem grandes quantidades de IL-4 e IL-13 dependendo da qualidade dos estímulos (IWAMURA; NAKAYAMA, 2010). Verificamos que a injeção intravenosa (i.v.) de subtilisina induziu o aumento de expressão da molécula de ativação CD69 em células iNKT (CD3 ${ }^{\text {int }}$ tetrâmero de CD1d ${ }^{+}$) hepáticas, mas não nas esplências, de maneira semelhante à induzida pela administração de $\alpha$-galactosilceramida ( $\alpha$ GalCer), usada como controle positivo (dados não mostrados). No entanto, a subtilisina foi incapaz de promover a produção de IL-4 ou IFN- $\gamma$ por estas células, como ocorreu com a injeção $\alpha$ GalCer nas iNKTs do fígado.

Em conjunto esses dados indicam que, a princípio, a subtilisina não tem uma ação efetiva e evidente na ativação direta de células imunes inatas e, portanto, a função alergênica decorrente de sua atividade enzimática deve ser reconhecida por outro tipo celular ou de uma maneira diferente da analisada por nosso grupo até agora.

\subsection{A subtilisina promove respostas inatas tipo II}

\subsubsection{Resposta de células epiteliais à subtilisina}

As respostas inatas tipo 2 são fundamentais para o desenvolvimento de respostas alérgicas adaptativas Th2 (LICONA-LIMÓN et al., 2013). Dentre os mecanismos celulares recém propostos, as células epiteliais desempenham importante função no reconhecimento de alérgenos (EBERL, 2010a; SAENZ; TAYLOR; ARTIS, 2008) e consequente geração de resposta alérgica. Além de serem o primeiro contato com alérgenos inalados, as células epiteliais representam um dos tipos celulares que mais expressam PAR-2 (UBL et al., 2002) e a sinalização induzida por este receptor pode levar à ativação desse tipo celular e originar uma resposta inflamatória (KATO et al., 2009a). Dessa forma, a participação das células epiteliais deve ser crucial no reconhecimento direto da subtilisina e indução de inflamação tipo 2 e, por 
isto, investigamos o efeito das proteases estudadas até o momento, subtilisina ou papaína, na ativação dessas células e indução de citocinas pró-Th2.

A expressão gênica de IL-1 $\alpha$, IL-33, TSLP e anfiregulina (Areg) foi determinada em células epiteliais brônquicas humanas de linhagem (H292) por PCR em tempo real após estímulo com protease por 3 ou 6 horas. A Areg é um fator de crescimento membro da família EGF (epidermal growth factor) que promove a proliferação e reparo tecidual e já foi previamente reconhecida como uma citocina pró Th2 (ZAISS et al., 2006). Como mostrado na figura 12, tanto a subtilisina quanto a papaína foram capazes de induzir a expressão das citocinas analisadas. Verificamos que as células tratadas com subtilisina induziram a expressão de IL-1 $\alpha$, TSLP e Areg preferencialmente após 3 h de estímulo, enquanto o aumento na expressão de IL-33 ocorreu depois de 6 h (figura 12). As citocinas IL-33, TSLP e o fator de crescimento Areg mostraram um maior aumento de expressão quando as células foram estimuladas com a dose de $10 \mu \mathrm{g}$ de subtilisina, ao passo que a expressão de IL-1 $\alpha$ foi semelhante para as concentrações utilizadas. A análise da expressão dessas citocinas após estímulo com papaína mostrou que esta protease também induz IL-1 $\alpha$ e TSLP preferencialmente após 3 h de estímulo, mas que IL-33 e Areg são induzidas de maneira semelhante após 3 ou $6 \mathrm{~h}$. Comparando as expressões dessas citocinas pelas proteases na dose de $10 \mu \mathrm{g}$, verificamos que a papaína induz mais IL-1 $\alpha$ do que a subtilisina, ao passo que a serino-protease subtilisina induz mais IL-33, TSLP e Areg do que a cisteíno-protease papaína. Estes dados demonstram que a subtilisina é capaz de ativar células epiteliais brônquicas e induz a expressão de citocinas pró-alérgicas rapidamente. Apesar de ambas as proteases terem um efeito geral semelhante na ativação dessas células por induzirem a expressão de diversas citocinas pró-alérgicas, a indução diferenciada (qualidade e quantidade) dessas citocinas pela subtilisina e papaína sugere que a geração da inflamação tipo 2 por células epiteliais se dá por diferentes vias de acordo com a protease e pode indicar mecanismos distintos de reconhecimento de serino e cisteíno proteases. 
Figura 12- A subtilisina induz citocinas pró-alérgicas e proteína de reparo em células epiteliais.
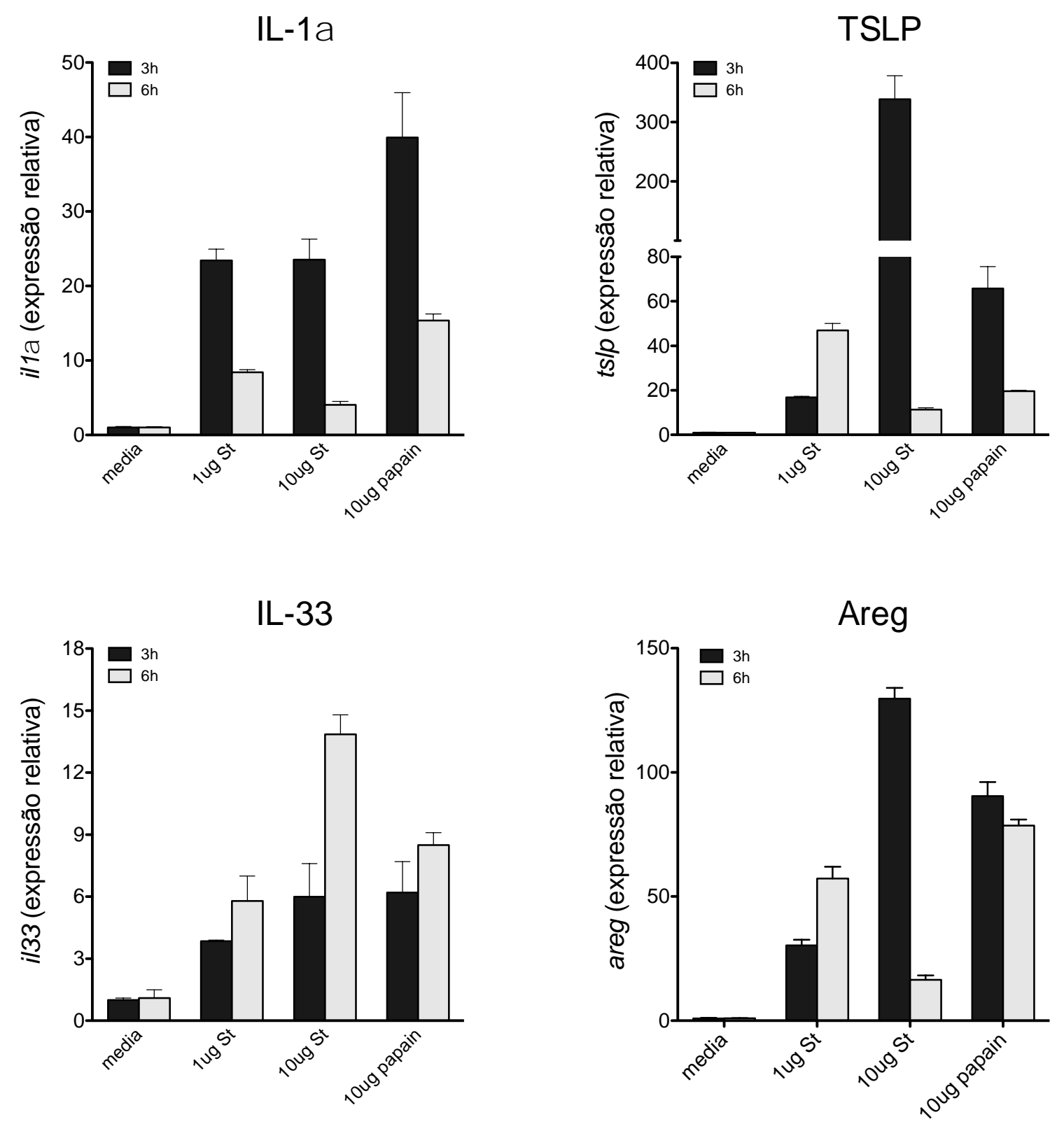

Expressão relativa de RNAm em células epiteliais brônquicas humanas de linhagem (H292) analisada por PCR em tempo real. As células foram estimuladas por 3 ou $6 \mathrm{~h}$ com subtilisina ou papaína nas concentrações indicadas. Representativo de três experimentos independentes, cada um realizado em triplicata. 
De maneira interessante, nenhuma das proteases induziu a expressão de IL-25 (ou IL17E), umas das citocinas associadas ao início de uma inflamação tipo II, ou Muc5b, principal molécula para formação de muco pelas células epiteliais (dados não mostrados).

Como havíamos mostrado que a resposta alérgica à subtilisina é dependente do PAR-2 e sabendo por outros grupos que a expressão deste receptor é significativa em células epiteliais, a próxima questão foi determinar se a subtilisina induz ativação de células epiteliais por uma via de sinalização dependente de PAR-2. Para isto gerou-se um RNA de interferência (RNAi) capaz de bloquear a expressão do PAR-2 nas células H292, utilizadas nos ensaios in vitro. Experimentos preliminares indicam que a resposta do epitélio à subtilisina é parcialmente dependente do PAR-2 (dados não mostrados). Utilizamos como indicador de ativação dessas células a fosforilação da proteína quinase intracelular S6, uma via canônica induzida por insulina (PRICE; GUNSALUS; AVRUCH, 1990) e cuja ativação foi verificada em resposta à papaína no laboratório do prof. Ruslan Medzhitov (dados não publicados). Verificamos por microscopia high-throughput (PEPPERKOK; ELLENBERG, 2006) que a subtilisina também promoveu a fosforilação da S6 em células H292 semelhante à papaína (dados não mostrados). No entanto, nas células tratadas previamente com o RNAi para bloqueio do PAR-2, a ativação dessa quinase foi parcial quando comparada a células tratadas com RNAi controle ou com células ativadas por insulina (dados não mostrados). Estes dados precisam ser repetidos e analisados de outras maneiras, mas se forem corroborados podem significar que o PAR-2 não é o único receptor responsável pela resposta à subtilisina no epitélio. Pode ser que haja um outro receptor que reconheça a atividade enzimática da subtilisina ou ainda que efeitos indiretos desta atividade no epitélio sejam reconhecidas de maneira distinta. Voltaremos a comentar sobre esta segunda possibilidade mais adiante, na Discussão.

\subsubsection{Células linfóides inatas tipo 2}

As células linfóides inatas tipo 2 (ILC2) foram descobertas recentemente e de maneira independente por diferentes grupos, como citado na Introdução. Elas são componentes da imunidade inata e grandes produtoras de citocinas como IL-5 e IL-13. Mais recente ainda, mostrou-se que essas ILC2 são fundamentais para o desenvolvimento da resposta alérgica (HALIM et al., 2014). Citocinas derivadas do epitélio, principalmente IL-33, são potentes ativadoras de ILC2 e, não por acaso, estas células expressam altos níveis do receptor de IL33, T1/ST2. Por esses motivos e também porque verificamos uma expressão aumentada de 
IL-33 nas células epiteliais em resposta à subtilisina, resolvemos investigar a ação desta serino protease na produção de citocinas Th2 pelas ILC2.

Como estas células são encontradas no pulmão (HALIM et al., 2014), decidimos, primeiramente, caracterizar as populações de ILC2 constitutivas e induzidas por tratamento com IL-25 (IL-17E) recombinante, como descrito previamente (NEILL et al., 2010). Verificamos que, de fato, existe uma população de ILC2 constitutiva no pulmão de animais C57BL/6 (grupo PBS) -população esta caracterizada como conjunto de células hematopoiéticas $\left(\mathrm{CD}^{4} 5^{+}\right)$que não expressam marcadores fenotípicos de linhagens clássicas (lin`) a não ser o indicador de linhagem tímica, Thy-1.2 ou CD90.2- e estas células produzem IL-5 continuamente (figura 13A), confirmando dados prévios já publicados (PRICE et al., 2010). Como já observado (NEILL et al., 2010), o tratamento com IL-25r induziu o aumento das ILC2 pulmonares e a ativação dessas células, indicada pelo aumento da produção de IL13 por estas células (figura 13A). A análise fenotípica de moléculas de superfície características dessas células mostrou que a administração de IL-25r pelas vias aéreas aumentou a expressão de c-kit (CD117) e de T1/ST2 (IL-33R) (figura 13B). No entanto, o tratamento com IL-25r não modulou a expressão de outras moléculas como CCR9 (receptor da quimiocina CCL25 expresso por células epiteliais) (figura 13B), Sca-1 (stem cell antigen1), IL-17RB (subunidade específica do receptor de IL-25) ou CD127 (receptor $\alpha$ da IL-7) (dados não mostrados). Estas moléculas já foram previamente descritas em ILC2 (SPITS; CUPEDO, 2012). Cabe ressaltar que ILC2 pulmonares (células selecionadas por beads magnéticas como lin $^{-}$) provenientes de animais WT não tratados com IL-25r apresentam expressão de T1/ST2 aumentada após estimulação in vitro com IL-7 e IL-33 (dados não mostrados). Para finalizar a caracterização parcial das ILC2, verificamos que o aumento desta população no pulmão induzida pela administração de IL-25r foi consequência da proliferação das ILC2 constitutivas já que houve maior incorporação de BrdU por essas células em animais que receberam IL-25r, comparado aos que receberam apenas PBS (figura 13C).

A seguir, determinamos se a exposição de subtilisina diretamente nas vias aéreas teria efeito na população de ILC2 pulmonares. De maneira interessante, a administração intranasal de subtilisina por 3 dias consecutivos (protocolo 2) induziu o aumento das ILC2 (CD45 Thy-1.2 $2^{+}$inn $^{-} \mathrm{IL}^{-} 5^{+}$) pulmonares (figura 13D) e ativação (IL-13 ${ }^{+}$, dados não mostrados) destas células. Mais interessante ainda, animais deficientes de PAR-2 não apresentaram esse aumento e ativação na população de ILC2 induzido pela subtilisina (figura 13D e dados não mostrados, respectivamente), o que sugere a participação decisiva deste receptor na resposta de ILC2 induzida pela subtilisina. Resultados preliminares indicam que o aumento da 
população de ILC2 no pulmão em resposta à subtilisina é também devido à proliferação celular e não ao recrutamento dessas células (por incorporação de BrdU), assim como verificado para a administração de IL-25r descrito anteriormente (dados não mostrados). 
Figura 13- Caracterização de células linfóides inatas tipo 2 (ILC2) pulmonares após administração intranasal de IL-25r ou subtilisina.

A
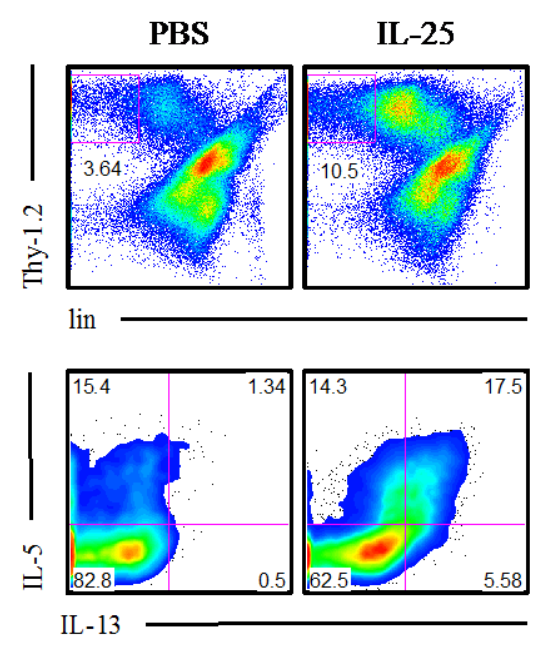

C

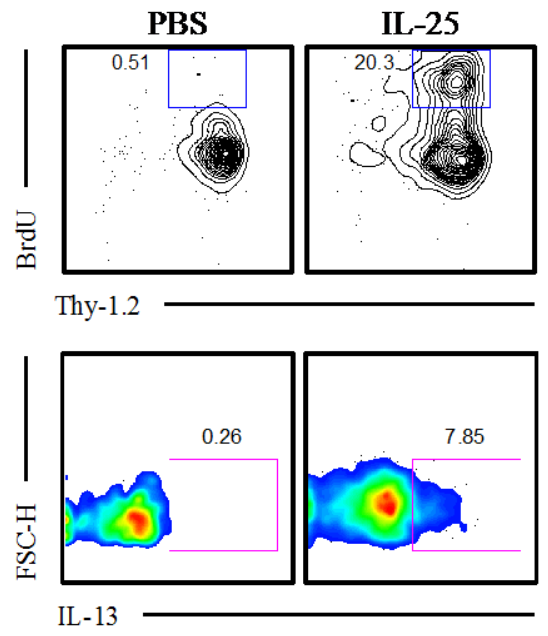

B

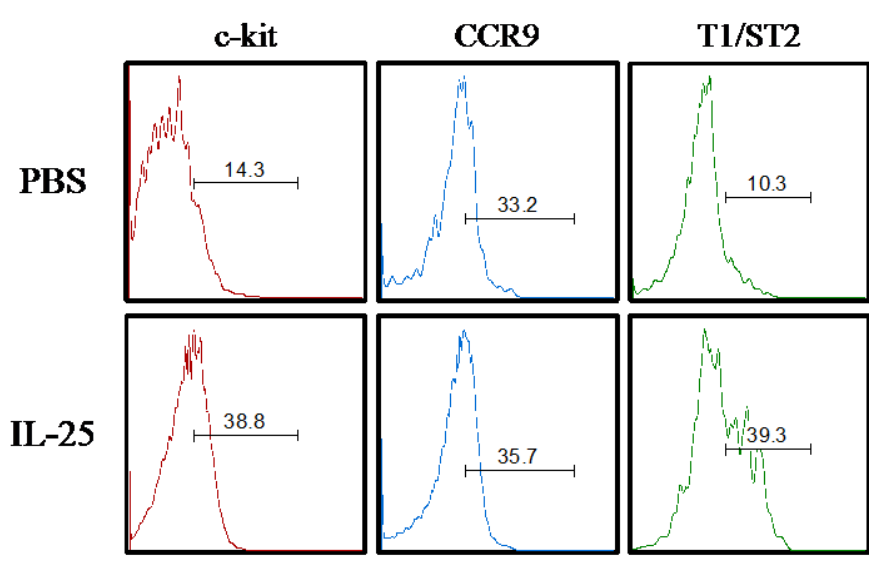

D

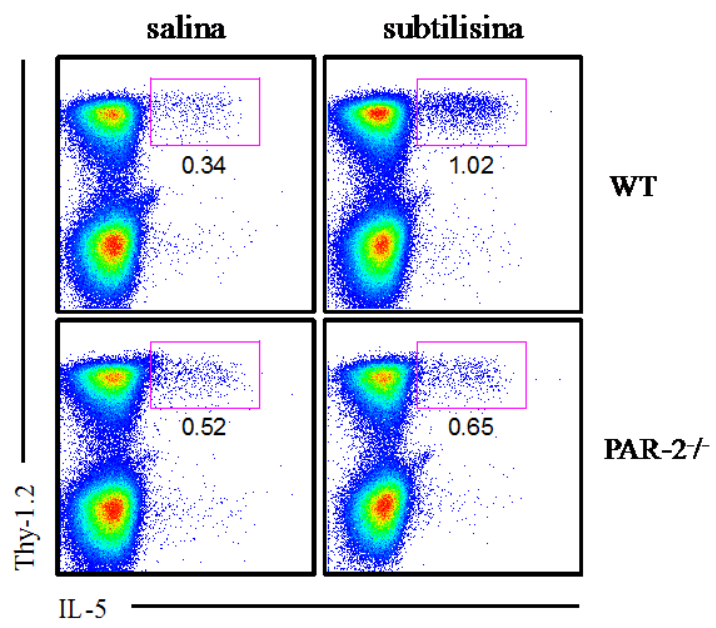

Camundongos C57BL/6 WT receberam PBS ou 0,4 $\mu \mathrm{g}$ de rIL-25 murino por via i.n. por 3 dias consecutivos e as células do pulmão foram analisadas no dia 4 (protocolo 2), após seleção negativa com marcadores de linhagens (lin') por beads magnéticas e estimulação in vitro com PMA/ionomicina como descrito em Metodologia. Frequência de Thy- $1.2^{+}$lin $^{-}$após seleção em células $\mathrm{CD}_{4} 5^{+}$(A, acima) e produção por essas células de citocinas tipo 2, IL-5 e IL-13 (A, abaixo). Expressão das moléculas de superfície c-kit (CD127), CCR9 e T1/ST2 em células pulmonares CD45 $5^{+}$Thy-1.2 $2^{+}$lin de animais que receberam PBS ou IL-25, mostrada como intensidade de fluorescência média (MFI) (B). Animais WT que receberam PBS ou IL$25 \mathrm{r}$ foram injetados com BrdU via i.p. por 3 dias consecutivos, concomitante com o protocolo descrito acima. Frequência de células BrdU+ Thy-1.2+ selecionadas como CD45 ${ }^{+}$lin $^{-}$ previamente (acima) e produção de IL-13 pelas células $\mathrm{BrdU}^{+}$Thy-1.2 $2^{+}$(abaixo) (C). Camundongos C57BL/6 WT ou PAR $-2 \%$ receberam 1,0 $\mu \mathrm{g}$ de subtilisina i.n. por 3 dias consecutivos e as populações celulares presentes no pulmão foram analisadas no dia 4 (protocolo 2) após estimulação in vitro com PMA/ionomicina. Frequência de ILC2 (Thy-1.2 ${ }^{+}$ IL- $5^{+}$) no dia 4 (D). Representativo de dois experimentos independentes ( $\left.\mathrm{n}=5\right)$, nos quais foram adquiridos ao menos $2,0 \times 10^{6}$ eventos totais para análise por citometria. Para cada amostra foram adquiridos pelo menos $1,0 \times 10^{6}$ eventos totais. 


\subsection{A inflamação tipo 2 induzida por subtilisina intranasal é dependente do PAR-2, do receptor de IL-33, ST2, e de MyD88}

A partir da observação de que a subtilisina exerce um efeito pró-inflamatório tanto nas células epiteliais quanto nas células ILC2, decidimos estabelecer um modelo in vivo de inflamação alérgica pulmonar induzida pela exposição à subtilisina intranasal. Para isto, animais receberam subtilisina por via i.n. nos dias 0 e 7 e as análises foram realizadas no dia 8, seguindo o protocolo 3 e como já mostrado para a papaína (KAMIJO et al., 2013). Utilizando este protocolo experimental verificamos que houve o aumento do influxo celular ao BAL de animais C57BL/6 WT em resposta à subtilisina (figura 14A). Dentre esse total de células no BAL, quase metade do influxo induzido pela subtilisina foi de eosinófilos (figura 14B). Surpreendentemente, foi possível encontrar níveis de IgE total no soro de animais WT administrados por via i.n. com a enzima, ainda que a concentração deste isotipo seja menor comparado à resposta alérgica induzida pela sensibilização s.c. com subtilisina e não tenha alcançado significância estatística neste experimento (figura 14C). Portanto, definimos um modelo de inflamação eosinofílica induzido por subtilisina apenas por exposição pelas vias aéreas.

Dado a importância do PAR-2 no desenvolvimento da imunidade tipo 2 promovida pela subtilisina por sensibilização s.c., resolvemos determinar a participação deste receptor na inflamação alérgica induzida pela subtilisina pelas vias aéreas. Animais deficientes de PAR-2 não apresentaram uma reação alérgica eosinofílica significativa quando comparados aos animais WT (figura 14A e B), nem foram capazes de produzir IgE total em resposta à subtilisina por via i.n. (figura 14C). Portanto, sugere-se que o PAR-2 seja fundamental na alergia induzida por exposição à subtilisina, seja ela por via s.c. (figura 10) como pelas vias aéreas (figura 14). 
Figura 14- Administração intranasal de subtilisina promove respostas tipo 2 dependente de PAR-2.

A

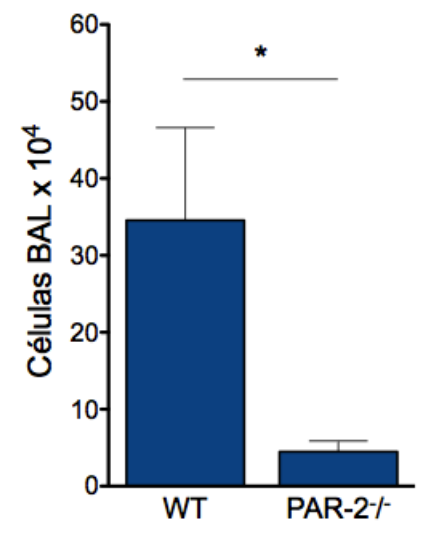

B

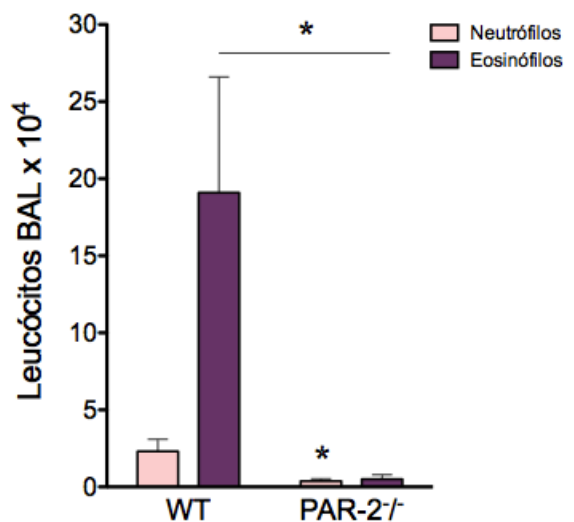

C

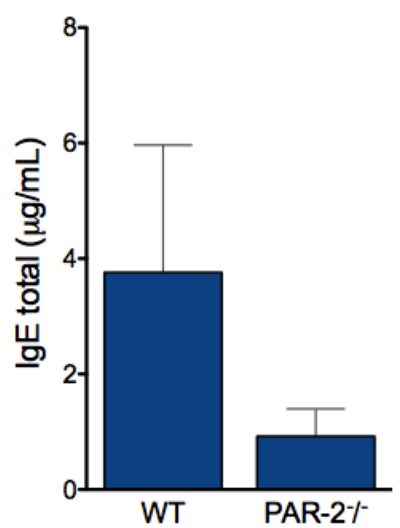

Para indução de inflamação das vias aéreas, camundongos C57BL/6 WT ou PAR-2\% receberam subtilisina intranasal nos dias 0 e 7 e as análises foram realizadas no dia 8 (protocolo 3). Número total de células $(\mathbf{A})$ e granulócitos $(\mathbf{B})$ presentes no BAL. Produção sistêmica de IgE total (D). Representativo de dois experimentos independentes $(n=5)$. 
A sinalização por IL-33 é um potente indutor de ILC2 (SPOONER et al., 2013) e do início da imunidade tipo 2 (TOWNSEND et al., 2000). À medida em que verificamos a indução e ativação de ILC2 pulmonares pela subtilisina, decidimos investigar a participação dessa via de IL-33 no desenvolvimento da inflamação alérgica induzida pela serino protease no modelo de sensibilização pelas vias aéreas. Em animais deficientes no receptor de IL-33, ST2 (Il1rl1\%), o recrutamento de eosinófilos induzido pela sensibilização intranasal à subtilisina (protocolo 3) foi significativamente menor, enquanto o influxo de neutrófilos foi maior nesses animais comparado aos camundongos WT (figura 15A). Resultados semelhantes foram encontrados por análise de citometria de fluxon em células presentes no BAL e pulmão (figura 15B). Ainda, animais deficientes de ST2 mostraram uma menor produção de IL-5 e IL-13 por linfócitos T convencionais pulmonares $\left(\mathrm{CD}^{+} \mathrm{CD}^{+}\right)$(figura 15C). Estes resultados indicam que a subtilisina induz uma resposta Th2 pela ativação do receptor ST2, que sinaliza via MyD88 (KAKKAR; LEE, 2008). Em concordância, também verificamos a participação crítica dessa molécula adaptadora, MyD88, na resposta à subtilisina intranasal já que animais deficientes de MyD88 exibiram recrutamento de células inflamatórias ao BAL intensamente diminuído e baixíssima, ou quase nenhuma, produção de IL-5 e IL-13 por linfócitos T pulmonares comparados aos animais WT (figura 15). Estes resultados indicam que a sinalização por MyD88 é essencial para o desenvolvimento da resposta alérgica à subtilisina. 
Figura 15- A inflamação alérgica induzida por subtilisina nas vias aéreas é dependente do receptor de IL-33, ST2, e de MyD88.

A
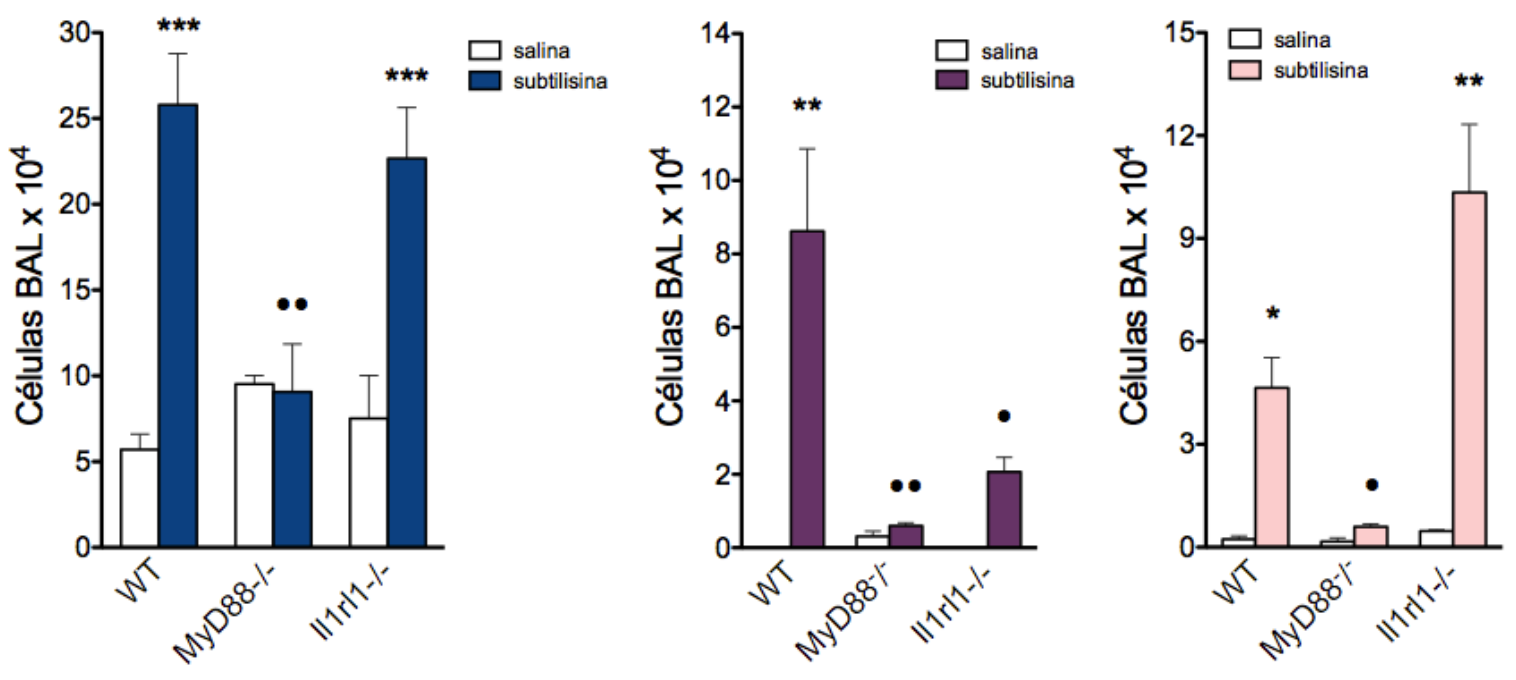

B

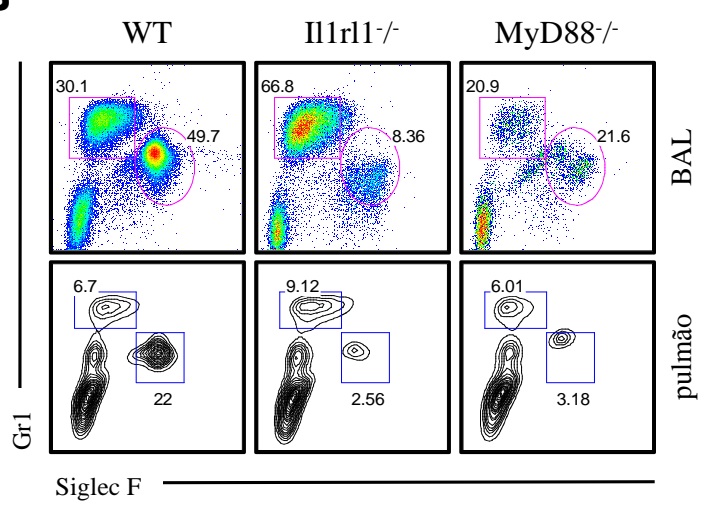

C

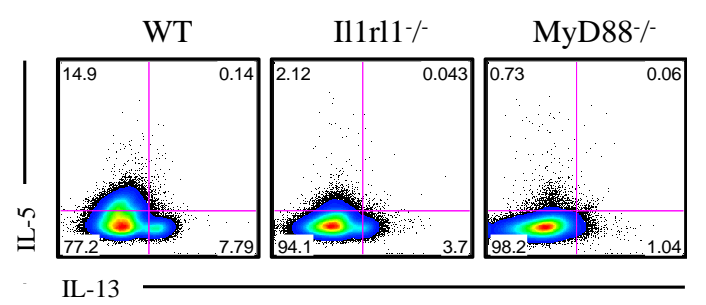

Camundongos C57BL/6, I11 $111 \%$ ou MyD88\% foram administrados com subtilisina pelas vias aéreas nos dias 0 e 7 e as análises realizadas no dia 8 (protocolo 3). Número total de células (esquerda), eosinófilos (meio) e neutrófilos (direita) presentes no BAL (A). Análise de células $\mathrm{CD}^{+} 5^{+} \mathrm{MHCII}^{-}$do BAL ou pulmão por citometria de fluxo de animais que receberam subtilisina $(\mathbf{B})$. Frequência de células pulmonares $\mathrm{CD} 45^{+} \mathrm{CD} 3^{+} \mathrm{CD} 4^{+}$estimuladas com PMA/ionomicina por $5 \mathrm{~h}(\mathbf{C})$. Representativo de dois experimentos independentes $(n=5)$. 


\subsection{Subtilisina intranasal promove sensibilização alérgica à OVA}

Como a subtilisina foi capaz de promover respostas alérgicas inatas no pulmão, testamos se esta serino protease poderia funcionar como um adjuvante Th2, induzindo uma resposta alérgica a um antígeno não correlacionado (bystander). Escolhemos utilizar a OVA como antígeno, já que sua administração pelas vias aéreas não resulta em inflamação alérgica (27). Camundongos C57BL/6 sensibilizados pelas vias aéreas com subtilisina e OVA e desafiados apenas com OVA, seguindo o protocolo 4, mostraram um influxo celular intenso ao BAL (figura 16A e B), aumento dos anticorpos $\operatorname{IgE}$ total, $\operatorname{IgE}$ e $\operatorname{IgG} 1$ específicas (figura 16C), e formação de muco em células epiteliais brônquicas (figura 16D). No entanto, a sensibilização com uma forma inativa da enzima não foi capaz de induzir a inflamação alérgica das vias aéreas, produção de anticorpos relacionados à resposta Th2 ou secreção de muco (figura 16). Esses dados sugerem que a subtilisina promove inflamação alérgica a proteínas não relacionadas (ou não alergênicas) e sua atividade enzimática é, novamente, fundamental para a sensibilização Th2. 
Figura 16- A subtilisina exerce atividade adjuvante à OVA.
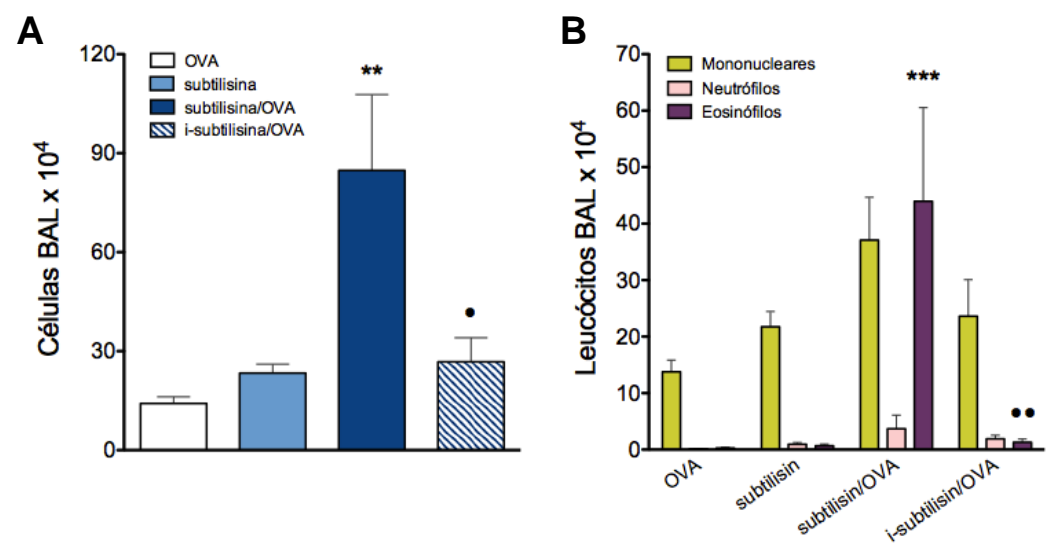

D
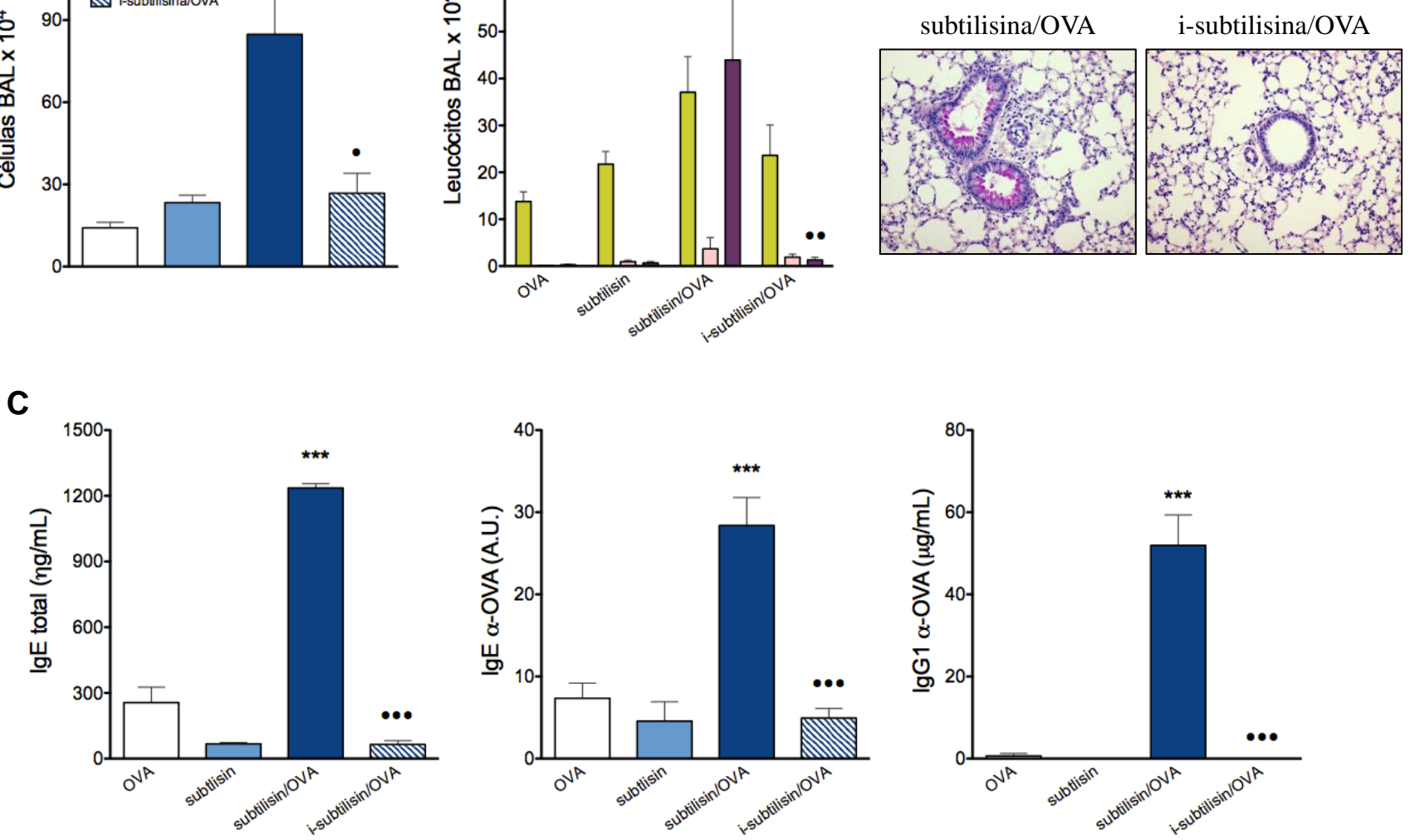

Animais C57BL/6 foram sensibilizados com OVA e subtilisina ativa ou inativada por calor por via intranasal nos dias 0 e 7 e desafiados com OVA intranasal nos dias 14 e 21, conforme descrito na Metodologia. Os grupos controles receberam somente OVA ou subtilisina na sensibilização e foram desafiados com OVA. Número total (A) e diferencial (B) de células do lavado broncoalveolar (BAL). Produção sistêmica de $\operatorname{IgE}$ total (C, esquerda), IgE e IgG1 OVA-específicas (C, meio e direita, respectivamente). Seções histológicas de tecido pulmonar mostrando a produção de muco e o infiltrado celular (D), em aumento de 200x. Representativo de três experimentos independentes $(\mathrm{n}=5)$. 
Das doenças pulmonares ocupacionais, a asma alérgica é a mais prevalente. Mais da metade dos casos de asma ocupacional está associada à exposição a proteases. A subtilisina de Carlsberg ou alcalase, uma serino protease proveniente de Bacillus subtilis, foi amplamente utilizada na fabricação de detergentes a partir da década de 60. Apesar de apresentar grande potencial alergênico e ter sido uma das principais enzimas responsáveis pela alta incidência de asma ocupacional nas indústrias de detergente, nenhum modelo experimental de inflamação alérgica pulmonar induzida por esta protease ainda tinha sido estabelecido. Neste trabalho, desenvolvemos um modelo murino de doença alérgica das vias aéreas à subtilisina e mostramos que esta enzima é um potente indutor da imunidade tipo 2 convencional em camundongos, incluindo respostas celulares Th2 e ILC2, produção de IgE, formação de muco e reatividade das vias aéreas. Nossos resultados mostram que a habilidade da subtilisina em induzir respostas tipo 2 é dependente da sua atividade enzimática e da sinalização via PAR-2, IL-1R, IL-33R ST2 e MyD88. Estes dados reforçam a hipótese de que a detecção de atividades enzimáticas presentes em alérgenos pelo sistema imune "inato" pode promover respostas Th2 e IgE (SHAKIB; GHAEMMAGHAMI; SEWELL, 2008; WILLSKARP et al., 2010).

A subtilisina foi identificada como um alérgeno potente logo após sua utilização pela indústria de detergente. As descrições dos sintomas clínicos indicaram que quase $50 \%$ dos trabalhadores desenvolveram asma alérgica, com hiper-reatividade brônquica (AHR) e presença de IgE (FALLERONI; SCHWARTZ, 1971; SCHWEIGERT; MACKENZIE; SARLO, 2000). Poucos grupos haviam pesquisado o efeito alergênico da subtilisina em modelos animais e estes estudos foram realizados em cobaias, por sensibilização intratraqueal (RITZ et al., 1993) ou em camundongos BALB/c por sensibilização via i.n. (ROBINSON et al., 1996). No entanto, nestes estudo apenas a produção de IgG1 específica à enzima foi analisada e a natureza dos mecanismos de indução de resposta alérgica não foram elucidados. Em contrapartida, o modelo murino que estabelecemos foi capaz de reproduzir diversos parâmetros que caracterizam uma resposta alérgica típica, como AHR, reatividade brônquica, eosinofilia pulmonar, produção de muco, citocinas tipo 2 e aumento de IgE total.

A presente avaliação em modelo murino de asma alérgica confirma o potencial de sensibilização da subtilisina mesmo na ausência de alum, um adjuvante Th2 clássico. De fato, nosso trabalho indica que a utilização do alum não representa uma boa estratégia de imunização para a maximização de respostas a proteases, já que este adjuvante exerce ação inibitória na atividade enzimática, tanto de serino quanto de cisteíno protease. 
O alum é um dos adjuvantes mais conhecidos e vem sendo utilizado há mais de 60 anos em vacinação humana contra difteria, tétano e coqueluche (PETROVSKY; AGUILAR, 2004). O alum ativa a imunidade inata in vivo, promove uma resposta preferencialmente $\mathrm{T}_{\mathrm{H}} 2$ e aumenta os isotipos dependentes de Th2, IgG1 e IgE (JORDAN et al., 2004). Apesar de sua utilização por várias décadas na pesquisa clínica, o efeito desse adjuvante ainda não foi totalmente esclarecido. Alguns trabalhos sugeriram que o alum induz a ativação de caspase-1, por uma via dependente de NALP3, estimulando a produção de IL-1 $\beta$ e IL-18 (EISENBARTH et al., 2008; HORNUNG et al., 2008; MAYOR et al., 2006). O NALP3 é um receptor citosólico e pertence à família dos NLRs (nod-like receptors). Além da ativação de NALP3, o alum pode induzir a produção de IL-4 por granulócitos (ou células Gr1 ${ }^{+}$) e parece inibir respostas do tipo $T_{H} 1$, favorecendo a diferenciação de células para um padrão $T_{H} 2$ (BREWER et al., 1996). Outro trabalho recente sugeriu que essa inflamação é resultado da liberação de DNA do organismo em consequência da necrose celular induzida por alum e que a imunidade adaptativa -produção de IgE e diferenciação de linfócitos Th2- é dependente do fator de transcrição IRF3, via molécula adaptadora citosólica Tbk1 e receptor desconhecido, em resposta ao DNA próprio (MARICHAL et al., 2011). Mesmo assim, os mecanismos induzidos pelo alum que levam à imunidade tipo II não são totalmente entendidos.

Apesar do efeito inflamatório potente do alum, nesta parte do trabalho mostramos que sua utilização não foi necessária para a geração da resposta alérgica à subtilisina. Portanto, a subtilisina representa um alérgeno natural e eficiente, capaz de ativar uma resposta imunológica adaptativa $T_{H} 2$ de maneira independente da sensibilização com alum. Ainda que a maioria dos modelos para estudo de respostas alérgicas e asma se baseie na sensibilização com alum (EISENBARTH, 2008), alguns grupos já demonstraram o efeito alergênico em protocolos livres de adjuvante (CONRAD et al., 2009; SUDHA; ARORA; SINGH, 2009). Estes grupos mostraram que a sensibilização pela via subcutânea a antígenos variados, como a serino protease de barata, Per a 10, $\beta$-galactosidase e até OVA, é capaz de gerar uma inflamação alérgica das vias aéreas independente do uso do alum. Inclusive, neste último trabalho, os autores mostram que a utilização do alum gera alteração de comportamento, com drástica redução na atividade locomotora logo após a injeção em camundongos sensibilizados e desafiados com OVA (CONRAD et al., 2009). Portanto, a utilização do alum tanto na clínica como em protocolos experimentais, deve ser melhor avaliada, já que a alternativa livre de adjuvante evita as complicações induzidas pelos adjuvantes não fisiológicos, que podem interferir no tratamento de asma e estratégias preventivas. 
Um dos aspectos interessantes no nosso modelo, independente da linhagem ou da via de sensibilização utilizada, foi a concentração de enzima capaz de induzir uma resposta alérgica. Trabalhos com proteases como a papaína, bromelaína ou ainda Der p 1, utilizaram uma concentração muito alta de enzima, de 50 a 500 vezes maior em relação à nossa. Estas concentrações raramente estão presentes naturalmente e, assim podem não representar a resposta fisiológica à exposição de alérgenos ubíquos no ambiente. Por isto, esta é uma vantagem do modelo de alergia à subtilisina estabelecido nesta tese.

A subtilisina utilizada em nosso modelo, também chamada de alcalase, se tornou um alérgeno enzimático de referência, após inúmeros casos de asma alérgica relatados por trabalhadores das indústrias de detergentes (American Conference of Governmental Industrial Hygienists. Threshold limit values and biological exposure indices. Cincinnati: ACGIH; 1990). Estabeleceu-se o valor limite de $60 \mathrm{ng} / \mathrm{m}^{3}$ para esta enzima e o potencial alergênico de outras proteases é baseado neste valor. Portanto, a quantidade necessária para que a subtilisina induza alergia é bastante baixa. Estudo pioneiro sobre a atividade imunológica da subtilisina mostrou que concentrações entre 0,3-1,0 $\mu \mathrm{g}$ da enzima foram suficientes para aumentar a produção de IgG1 anafilática em cobaias após 5 semanas de sensibilização via i.t. (SARLO et al., 1997a). Isto é bastante semelhante ao obtido em nossos protocolos de sensibilização, tanto pela via subcutânea quanto pelas vias aéreas.

Nossos dados sugerem que a resposta alérgica é causada pela atividade de serino protease da subtilisina e não apenas por sua estrutura terciária. No mesmo trabalho citado acima, Sarlo et al mostraram que a subtilisina conjugada com o inibidor específico DFP (diisopropyl fluorophosphate), sem nenhuma atividade enzimática, não conseguiu mais induzir o aumento da produção de IgG1 anafilática em cobaias (SARLO et al., 1997b). Assim, este grupo também já havia sugerido a importância fundamental da atividade enzimática na indução de resposta alérgica pela subtilisina.

Diversas evidências sugerem que a atividade proteásica intrínseca não só pode facilitar a sensibilização a alérgenos, por diminuir a integridade da barreira epitelial, ativar a expressão de citocinas e quimiocinas, como também afetar a inflamação crônica pulmonar e direcionar o remodelamento das vias aéreas seguido das interações com o epitélio brônquico (JACQUET, 2011). A parede do trato respiratório é constituída por epitélio pseudo-estratificado ciliado, no qual as células permanecem conectadas por junções do tipo tight ou zônulas de oclusão (HAMMAD; LAMBRECHT, 2008). Os alérgenos clinicamente relevantes (como Der p 1, esporos de Aspergillus spp e pólen de ragweed), que contém atividade de serino ou cisteíno protease, podem induzir inflamação aguda pela destruição da barreira epitelial. A clivagem 
das proteínas que mantém a união destas células pelas proteases, pode promover a entrada dos alérgenos ao espaço paracelular, onde estão diversas populações de macrófagos e DCs (RUNSWICK et al., 2007). A inflamação também pode ser induzida pela ligação a receptores presentes no endotélio, como PARs (protease-activated receptors) ou até TLRs. Assim, a subtilisina pode promover uma resposta aguda pulmonar pelo aumento da permeabilidade da mucosa aérea e acesso às DCs intraepiteliais, além da ativação epitelial. Favorecemos a hipótese de que o efeito alergênico da subtilisina, tanto por sensibilização s.c. como via i.n., é dependente da sinalização pelo PAR-2, como consequência do reconhecimento da atividade enzimática por este receptor acoplado à proteína G. No entanto, como esta sinalização é capaz de promover as atividades alérgicas, por exemplo a produção das citocinas derivadas do epitélio, no organismo precisa ser investigado.

Desenvolvemos também um modelo de asma alérgica induzida por uma cisteíno protease presente na planta Carica papaya, a papaína. Escolhemos esta enzima, pois alguns trabalhos haviam mencionado que a geração de resposta alérgica é dependente de sua atividade proteásica e ela é um alérgeno bastante utilizado em modelos de alergia alimentar. Além da papaína, alguns dos alérgenos que contém atividade de cisteíno protease são: Der $\mathrm{p}$ 1, bromelaína, extrato do ácaro Sarcoptes scabiei e extrato do fungo Alternaria alternata (BAUR; FRUHMANN, 1979b; KOUZAKI et al., 2009; WALTON et al., 2010). Concordante com a observação de que a atividade enzimática do alérgeno induz uma resposta $T_{H} 2$, mostramos em nosso modelo que a inflamação alérgica das vias aéreas induzida pela sensibilização s.c. com papaína também depende de sua atividade de cisteíno protease. $\mathrm{O}$ modelo com a papaína nos propiciou uma comparação interessante entre duas famílias distintas de protease bastante frequentes nos principais alérgenos: serino e cisteíno proteases. De fato, a sensibilização com a papaína induziu uma resposta alérgica acentuada, nas duas linhagens verificadas, C57BL/6 e BALB/c. Novamente, o mecanismo envolvido na geração de resposta imune do tipo $\mathrm{T}_{\mathrm{H}} 2$ por proteases ainda não foi totalmente entendido.

Ao contrário das respostas Th1 e Th17, o desenvolvimento da imunidade adaptativa Th2 ainda não é completamente entendido e continua bastante controverso. Por causa dessa complexidade, não deve haver apenas uma única forma responsável por esta resposta e que consiga explicar a atividade dos diversos alérgenos. O desafio será delinear os possíveis mecanismos envolvidos no início da resposta imune $\mathrm{T}_{\mathrm{H}} 2$ fisiológicas e patológicas.

Os mecanismos envolvidos na indução de respostas Th2 descritas para serino proteases tem em comum a ativação do PAR-2 (KATO et al., 2009a; PAGE et al., 2010; SHPACOVITCH et al., 2007b). De fato, verificamos a importância fundamental deste sensor 
de protease no desenvolvimento da resposta alérgica induzida pela subtilisina. Recentemente, Page e cols. mostraram a contribuição do PAR-2 na inflamação alérgica a proteases presentes em baratas apenas quando o alérgeno foi administrado pela mucosa das vias aéreas, mas não pela via peritoneal (PAGE et al., 2010). Em nossos estudos, o PAR-2 demonstrou ser necessário para a resposta alérgica à subtilisina tanto no protocolo de sensibilização pela via subcutânea quanto pela via intranasal.

À medida que as células epiteliais brônquicas humanas responderam diretamente à subtilisina e de forma rápida expressando citocinas pró-alérgicas -ao contrário de diversas outras células da imunidade inata testadas- hipotetizamos que essa é a principal população celular que reconhece a atividade da serino protease, via PAR-2. Foi mostrado que a sinalização por este receptor a partir do reconhecimento da atividade enzimática levou à produção da citocina TSLP em células epiteliais do trato respiratório (KOUZAKI et al., 2009). Além de sua importante função na sensibilização à subtilisina pelas vias aéreas, o PAR-2 também foi crítico na resposta induzida pela sensibilização subcutânea, sugerindo que outros tipos celulares podem estar envolvidos na alergia à enzima. Em concordância com esta ideia, proteases presentes em ácaros promoveram uma inflamação alérgica via ativação do PAR-2 em queratinócitos humanos (KATO et al., 2009a). Wilson e cols. mostraram que a produção de TSLP por queratinócitos, em modelo de dermatite atópica, depende da sinalização via PAR-2 e consequente influxo de $\mathrm{Ca}^{2+}$ e ativação e translocação de NFAT (WILSON et al., 2013). Apesar disto, a relação entre a ativação do PAR-2 e a indução do processo alérgico é pouco sabido. Mesmo que nossos resultados apontem para a participação essencial deste receptor, não podemos descartar a possibilidade de que há outros sensores e receptores envolvidos na indução da inflamação alérgica à subtilisina. Além disso, não sabemos em que momento da resposta induzida por esta protease o PAR-2 participa. Sabe-se que diversos ligantes endógenos liberados na inflamação, por exemplo a triptase, podem ativar este sensor (STEINHOFF et al., 2003).

As cisteíno proteases, por sua vez, não são descritas como ativadores eficientes do PAR-2 (ADAM et al., 2006; KATO et al., 2009b). Um artigo publicado recentemente sugeriu que a iniciação da resposta inflamatória por cisteíno proteases presentes no extrato de ácaros se dá nos queratinócitos pela ativação do inflamassoma NLRP3 (DAI et al., 2011). Esta resposta depende da atividade de cisteíno protease e a estimulação das células com Dermatophagoides pteronyssinus parece aumentar os níveis de HMGB1 (high-mobility group box protein1), um ligante endógeno potente na ativação de NLRP3 em células dendríticas (GHIRINGHELLI et al., 2009). No entanto, este trabalho só mostrou a produção de IL-1 $\beta$ e 
IL-18 pelos queratinócitos e as vias induzidas por estas citocinas não explicam a indução de inflamação tipo II que ocorre após a sensibilização a alérgenos.

Consistente com alguns trabalhos publicados, nossos resultados mostram que a eosinofilia promovida pela atividade enzimática da subtilisina às vias aéreas não depende de TLRs (toll-like receptors), mas sim, da sinalização via proteína adaptadora MyD88 (SOKOL et al., 2008). Isto indica que não deve haver nenhuma contaminação das amostras de enzimas com endotoxina, que explicaria uma possível ativação da resposta imune adaptativa. Ao contrário, Hammad et cols. mostraram que para a resposta alérgica induzida por extrato de ácaros de poeira doméstica (house dust mite) a sinalização por TLR4 é fundamental, provavelmente devido à presença de endotoxina no homogeneizado (HAMMAD et al., 2009). Outros grupos já verificaram que a resposta Th2 induzida por alérgenos pode ser iniciada por outras moléculas do tipo PAMPs (pathogen-associated molecular patterns) que induzem ativação de células epiteliais ou células dendríticas por receptores do tipo C-lectina ou mesmo TLR4 (NATHAN et al., 2009; TROMPETTE et al., 2009). Portanto e, de uma maneira geral, a sinalização proveniente da ativação dos receptores TLR4 não é necessária à imunidade tipo 2 em resposta à subtilisina.

Estudos recentes destacaram a função essencial da via IL-33/ST2 na inflamação tipo 2 e doenças alérgicas (TOWNSEND et al., 2000). A IL-33 desempenha uma importante participação nas respostas inatas tipo 2 induzindo a expansão de ILC2, que fornecem IL-5 e IL-13 e contribuem, dessa forma, para a inflamação respiratória ou gastrointestinal e nas respostas anti-helmínticas (OLIPHANT; BARLOW; MCKENZIE, 2011). Além disto, se demonstrou a importante participação de MyD88 e ST2 no direcionamento da resposta Th2 ao helminto Trichinella spiralis (SCALFONE et al., 2013). Aqui, mostramos que o ST2 é necessário para a indução de respostas Th2 induzidas pela subtilisina, ao menos no caso da sensibilização pelas vias aéreas.

A expressão de MyD88 é igualmente ou mais importante ainda para a resposta Th2 ótima à subtilisina. E devido à inibição da inflamação alérgica à subtilisina ser mais acentuada nos animais deficientes de MyD88 em relação aos deficientes do receptor para IL-33, nossa hipótese é de que uma outra citocina além da IL-33 e que também utilize a via de sinalização MyD88 desempenhe uma ação aditiva no nosso modelo. Baseados em nossos dados in vitro com células epiteliais e também apoiados trabalho anterior (WILLART et al., 2012), sugerimos que a IL-1 $\alpha$ seria a citocina responsável, em conjunto com IL-33, pelas respostas alérgicas verificadas à subtilisina. De fato, a expressão do receptor para IL-1 é fundamental na inflamação tipo 2 induzida pela sensibilização s.c. à subtilisina, o que sugere que IL-1 $\alpha$ e/ou 
IL-1 $\beta$ podem realmente representarem as citocinas que atuam em conjunto com IL-33 na promoção da alergia à enzima.

Nossos dados corroboram trabalhos anteriores à medida que reforça a ideia do epitélio como participante ativo no desenvolvimento de resposta inflamatória tipo 2. Mesmo tendo analisado apenas a expressão gênica das citocinas induzidas nas células epiteliais, outros trabalhos já reportaram a rápida produção dessas citocinas (pelo menos TSLP, IL-33 e IL-1 $\alpha$ ) in vivo em resposta à exposição a aeroalérgenos como HDM e papaína, bromelaína, como citado anteriormente. Mostramos, pela primeira vez, que uma serino protease induz anfiregulina (Areg) em células epiteliais e sugerimos mecanismos distintos de reconhecimento de diferentes classes de proteases pelo epitélio. É interessante notar que a resposta do epitélio é mais intensa para uma exposição mais rápida e em maior dose de subtilisina do que uma dose menor em tempo mais prolongado. Isto já poderia indicar que o sistema é mais responsivo à estímulos nocivos ou que percebe grandes alterações rapidamente e respondem de maneira mais intensa, enfatizando a noção de que respostas alérgicas são respostas de adaptação do organismo a potenciais indutores de dano tecidual. É claro que ação da subtilisina no epitélio não deve se restringir apenas a estas citocinas analisadas, afinal uma resposta inflamatória é bastante complexa e deve haver outras alterações biológicas neste tecido após a exposição à enzima em questão que podem contribuir igualmente para o desenvolvimento da resposta alérgica. Por exemplo, como alguns trabalhos já mostraram, proteases podem romper a adesão intercelular aumentando a permeabilidade e fragmentando a integridade da barreira epitelial (HERBERT et al., 1995; ROCHE et al., 2000). A sinalização que se segue nas células vizinhas inclui respostas metabólicas, estruturais que visam à reorganização e reparo do tecido injuriado. Ainda se conhece muito pouco da relação entre essas respostas homeostáticas e a indução de inflamação, mas certamente investigações mais aprofundadas neste assunto trarão maior clareza acerca dos mecanismos de reconhecimento de alérgenos.

Mais interessante ainda foi a descoberta, ainda não divulgada na literatura por nenum outro grupo, de que uma serino protease é uma potente indutora de ILC2 na mucosa pulmonar e que isto é dependente da expressão de PAR-2. Este novo subtipo celular representa grande proporção das células pulmonares produtoras de IL-5 e IL-13 (KLEIN WOLTERINK et al., 2012) e dados recentíssimos mostram que animais deficientes nesta população de ILC2 apresentam uma inflamação pulmonar bastante reduzida após administração i.n. de papaína (HALIM et al., 2012). Um estudo mais detalhado que investigue a contribuição da ILC2 e 
PAR-2 será necessário para uma melhor compreensão da interação entre a imunidade inata e adaptativa durante respostas tipo 2 .

O modo pelo qual os trabalhadores da indústria de detergente se sensibilizaram a serino proteases ainda não está completamente estabelecido. De acordo com nosso trabalho, eles poderiam ter se sensibilizado tanto pela via epicutânea como pela inalação da enzima, em forma de aerosol. Além de sensibilizar os camundongos diretamente, a subtilisina mostrou uma atividade adjuvante Th2 evidente a uma proteína não correlacionada e inócua, a OVA. Isto indica que a exposição à subtilisina poderia promover resposta alérgica à própria enzima ou, então, a neo-antígenos presentes no microambiente e, desta forma, aumentando o risco de desenvolvimento de asma a proteínas ambientais e desencadeamento de reações anafiláticas.

No conjunto, nossos trabalho define novos modelos de asma ocupacional induzida pela serino protease subtilisina e indica que o efeito alergênico da atividade da subtilisina depende da sinalização via PAR-2, IL-33/ST2, IL-1R e MyD88. Estas observações tem implicações em modelos de alergia induzido por proteases, principalmente por serino proteases, e também relevância clínica, à medida que a asma ocupacional por proteases ainda representa um grande problema sócio-econônimo mundial. 
6 CONSIDERAÇÕES FINAIS 
Os resultados obtidos neste estudo permitem as seguintes conclusões:

- a subtilisina é um potente indutor da inflamação alérgica pulmonar e da imunidade tipo II em modelo experimental;

- a utilização do adjuvante alum é dispensável na sensibilização alérgica à subtilisina;

- a atividade de serino protease da subtilisina é fundamental para o desenvolvimento da inflamação alérgica pulmonar;

- $\quad$ as respostas tipo II induzidas pela subtilisina são dependentes dos receptores PAR-2, T1/ST2 e IL-1R e da molécula adaptadora MyD88;

- a subtilisina promove ativação das células linfóides inatas tipo 2 (ILC2) de maneira dependente do receptor PAR-2;

- a subtilisina não induz ativação clássica de células dendríticas diretamente;

- células epiteliais respondem à subtilisina e produzem citocinas próinflamatórias tipo 2 e molécula de reparo tecidual;

- $\quad$ a atividade enzimática da subtilisina exerce função adjuvante na sensibilização à um antígeno inócuo pelas vias aéreas.

A partir das nossas observações, propomos um esquema representativo de como as respostas tipo 2 são iniciadas e propagadas a partir da exposição à subtilisina (Figura 17). No modelo que sugerimos, a fase inicial seria de reconhecimento da atividade enzimática da subtilisina pelo epitélio. As células epiteliais estimuladas via receptor PAR-2 secretam citocinas como IL-1 $\alpha$, IL-33, TSLP e o fator Areg. Estas citocinas derivadas do epitélio ativam as células ILC2 (principalmente via IL-33), que produzem citocinas tipo II e DCs (via TSLP e IL-1 $\alpha$ ), que induzem a resposta Th2 (IL-4). As citocinas tipo II secretadas pelas ILC2 podem agir no epitélio, induzindo a diferenciação de células produtoras de muco (IL-13) e reparo tecidual (Areg). A produção de IL-5 pelas ILC2 promovem o recrutamento e ativação de eosinófilos. A ativação posterior de linfócitos T nos órgãos linfóides amplifica a produção das citocinas tipo II e a secreção de IL-4 por estes linfócitos diferenciados em Th2 leva à troca de isotipo para $\operatorname{IgE}$ em linfócitos B. Este isotipo se associa aos receptores de alta afinidade e pode ativar mastócitos no tecido, que contribui para as características cardinais da inflamação alérgica. 
Figura 17- Início e desenvolvimento de respostas tipo II promovidas pela subtilisina: proposta de modelo.

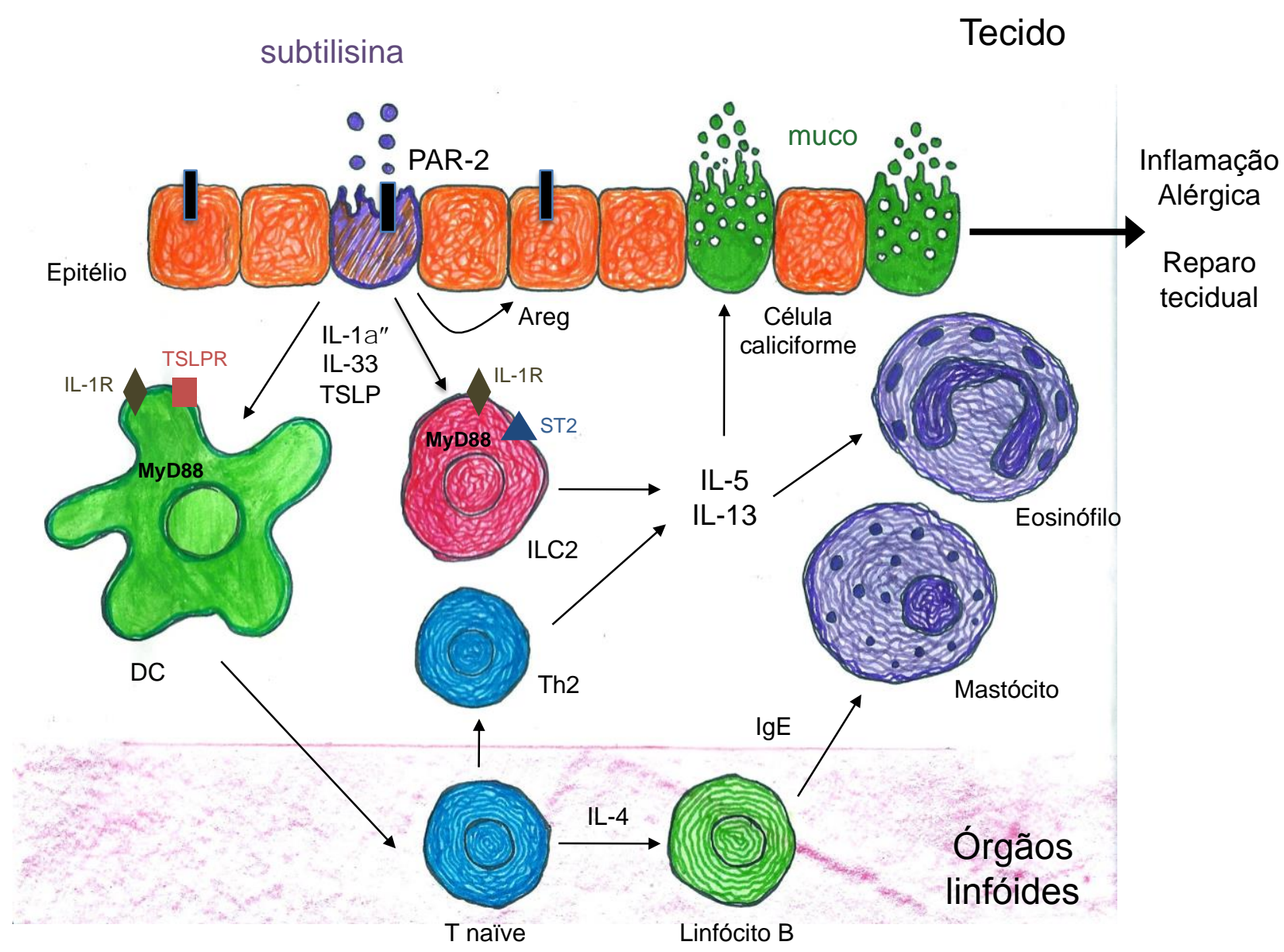

As respostas tipo II são iniciadas pelo reconhecimento da atividade de serino protease da subtilisina pelo receptor PAR-2 expresso em células epiteliais. Estas células secretam as citocinas IL-1 $\alpha$, IL-33, TSLP e o fator de crescimento Areg (anfiregulina). A IL-33 e IL-1 $\alpha$ podem ativar as células ILC2, via IL-1R e T1/ST2 (ST2), respectivamente, a produzirem IL-5 e IL-13, enquanto a IL-1 $\alpha$ e TSLP promovem a ativação de DCs, via IL-1R e TSLPR, respectivamente. Estas citocinas derivadas do epitélio ativam as células ILC2 (principalmente via IL-33), que produzem citocinas tipo II, e DCs (via TSLP e IL-1 $\alpha$ ), que induzem a resposta Th2 (via produção de IL-4). As citocinas tipo II secretadas pelas ILC2 podem agir no epitélio, induzindo a diferenciação de células produtoras de muco (IL-13) e reparo tecidual (Areg). A produção de IL-5 pelas ILC2 promovem o recrutamento e ativação de eosinófilos. A ativação posterior de linfócitos Th2 nos órgãos linfóides amplifica a produção das citocinas tipo II, IL-5 e IL-13, e a secreção de IL-4 por estes linfócitos leva à troca de isotipo para IgE em linfócitos B. Este isotipo pode ativar mastócitos no tecido, que contribui para as principais características da inflamação alérgica. Esquema baseado em figura do artigo "Th2, allergy and group 2 innate lymphoid cells" (LICONA-LIMÓN et al., 2013). 
Como ocorre com todos os trabalhos científicos, uma das consequências do nosso estudo é a geração de mais perguntas e vou sumarizar a seguir as que considero mais interessantes para futuras pesquisas nesta área (são direcionadas à subtilisina, mas podem representar questões gerais em Alergia):

- Em que células a expressão de PAR-2 é necessária para induzir uma resposta alérgica?

- Quais são os mecanismos responsáveis pelo efeito adjuvante da atividade enzimática da subtilisina?

- Qual é a participação das células linfóides inatas tipo 2 (ILC2) na inflamação alérgica à subtilisina?

- Como a ativação do receptor PAR-2 leva à produção de citocinas tipo 2 próinflamatórias e, consequentemente, contribui para o estabelecimento de alergia? Este fenômeno ocorre na mesma célula epitelial ou é um efeito indireto?

- Em que células a sinalização via MyD88 é necessária para o início da resposta tipo II à subtilisina?

- Como as células epiteliais reconhecem a subtilisina e percebem sua atividade enzimática? O PAR-2 seria o único sensor?

- Que subtipos epiteliais reconhecem a atividade da enzima e induzem a liberação de citocinas pró-Th2? Poderiam existir células epiteliais secretórias especializadas?

- A inflamação alérgica induzida pela subtilisina em modelo experimental pode ficar crônica?

- Além das células epiteliais, outros tipos celulares não-imunológicos, tipo neurônios sensitivos, poderiam contribuir na indução da resposta alérgica à subtilisina?

- Como as células dendríticas (DCs) podem contribuir na sensibilização alérgica à subtilisina, se não de forma direta? Como se atinge a especificidade da resposta adaptativa neste caso?

- Quais seriam as funções dos mastócitos e basófilos para a inflamação tipo II no modelo experimental de asma ocupacional à subtilisina?

- Como as citocinas tipo 2 (IL-1 $\alpha$, IL-33, TSLP e Areg) promovem a resposta Th2? Estas citocinas são também induzidas in vivo da mesma forma?

Ademais, esperamos ter contribuído com algumas evidências para pensar o processo inflamatório alérgico de uma maneira mais fisiológica ou homeostática e desconstruir a noção da alergia como uma atividade essencialmente patológica assim como a ideia do sistema imunológico como "defesa". 


\section{REFERÊNCIAS ${ }^{*}$}

ADAM, E. et al. The house dust mite allergen Der $\mathrm{p} \mathrm{1,} \mathrm{unlike} \mathrm{Der} \mathrm{p} \mathrm{3,} \mathrm{stimulates} \mathrm{the}$ expression of interleukin-8 in human airway epithelial cells via a proteinase-activated receptor-2-independent mechanism. The Journal of Biological Chemistry, v. 281, n. 11, p. 6910-6923, 2006.

AIDA, Y.; PABST, M. J. Removal of endotoxin from protein solutions by phase separation using Triton X-114. Journal of Immunological Methods, v. 132, n. 2, p. 191-195, 14 set. 1990.

AINSWORTH, C. Into the breach Allergies Outlook. Nature, p. 2-3, 2011.

ALBERTINE, K. H. et al. Temporal correlation of measurements of airway hyperresponsiveness in ovalbumin-sensitized mice. American Journal of Physiology. Lung Cellular and Molecular Physiology, v. 283, n. 1, p. L219-233, jul. 2002.

ALLEN, J. E.; SUTHERLAND, T. E. Host protective roles of type 2 immunity: Parasite killing and tissue repair, flip sides of the same coin. Seminars in immunology, 11 jul. 2014.

ANGKASEKWINAI, P. et al. Interleukin 25 promotes the initiation of proallergic type 2 responses. The Journal of Experimental Medicine, v. 204, n. 7, p. 1509-1517, 9 jul. 2007.

ANSEL, K. M. et al. Regulation of Th2 differentiation and Il4 locus accessibility. Annual Review of Immunology, v. 24, p. 607-656, jan. 2006.

BAGAROZZI, D. A.; TRAVIS, J. Ragweed pollen proteolytic enzymes: possible roles in allergies and asthma. Phytochemistry, v. 47, n. 4, p. 593-598, fev. 1998.

BARNES, P. J.; ADCOCK, I. M. How do corticosteroids work in asthma? Annals of Internal Medicine, v. 139, n. 5 Pt 1, p. 359-370, 2 set. 2003.

BAUR, X. Enzymes as occupational and environmental respiratory sensitisers. International Archives of Occupational and Environmental Health, v. 78, n. 4, p. 279-286, maio 2005.

BAUR, X.; FRUHMANN, G. Papain-induced asthma: diagnosis by skin test, RAST and bronchial provocation test. Clinical Allergy, v. 9, n. 1, p. 75-81, jan. 1979a.

BAUR, X.; FRUHMANN, G. Allergic reactions, including asthma, to the pineapple protease bromelain following occupational exposure. Clinical Allergy, v. 9, n. 5, p. 443-450, set. $1979 b$.

BERGER, P. et al. Selected contribution: tryptase-induced PAR-2-mediated $\mathrm{Ca}(2+)$ signaling in human airway smooth muscle cells. Journal of Applied Physiology (Bethesda, Md.: 1985), v. 91, n. 2, p. 995-1003, ago. 2001.

BLASI, F.; CARMELIET, P. uPAR: a versatile signalling orchestrator. Nature Reviews. Molecular Cell Biology, v. 3, n. 12, p. 932-943, dez. 2002.

\footnotetext{
${ }^{*}$ De acordo com: ASSOCIAÇÃO BRASILEIRA DE NORMAS TÉCNICAS. NBR 6023: informação e documentação: referências: elaboração. Rio de Janeiro, 2002.
} 
BORTOLATTO, J. et al. Toll-like receptor 4 agonists adsorbed to aluminium hydroxide adjuvant attenuate ovalbumin-specific allergic airway disease: role of MyD88 adaptor molecule and interleukin-12/interferon-gamma axis. Clinical and Experimental Allergy : Journal of the British Society for Allergy and Clinical Immunology, v. 38, n. 10, p. 16681679, out. 2008.

BOSWELL-SMITH, V.; CAZZOLA, M.; PAGE, C. P. Are phosphodiesterase 4 inhibitors just more theophylline? The Journal of Allergy and Clinical Immunology, v. 117, n. 6, p. 1237-1243, jun. 2006.

BREWER, J. M. et al. In interleukin-4-deficient mice, alum not only generates T helper 1 responses equivalent to freund's complete adjuvant, but continues to induce $\mathrm{T}$ helper 2 cytokine production. European Journal of Immunology, v. 26, n. 9, p. 2062-2066, set. 1996.

BULEK, K. et al. Epithelium: the interplay between innate and Th2 immunity. Immunology and Cell Biology, v. 88, n. 3, p. 257-268, 2010a.

CARLSEN, K.-H.; CARLSEN, K. C. L. Exercise-induced asthma. Paediatric Respiratory reviews, v. 3, n. 2, p. 154-160, jun. 2002.

COCKS, T. M.; MOFFATT, J. D. Protease-activated receptor-2 (PAR2) in the airways. Pulmonary Pharmacology \& Therapeutics, v. 14, n. 3, p. 183-191, jan. 2001.

CONRAD, M. L. et al. Comparison of adjuvant and adjuvant-free murine experimental asthma models. Clinical and Experimental Allergy, v. 39, n. 8, p. 1246-1254, ago. 2009.

CULLINAN, P. et al. An outbreak of asthma in a modern detergent factory. The Lancet, v. 356, n. 9245, p. 1899-1900, 2000.

DAI, X. et al. Mite allergen is a danger signal for the skin via activation of inflammasome in keratinocytes. The Journal of Allergy and Clinical Immunology, v. 127, n. 3, p. 806814.e1-4, mar. 2011.

DATASUS. Ministério da Saúde do Brasil. Fonte: Departamento de Informática do SUS DATASUS, órgão da Secretaria Executiva do Ministério da Saúde. Disponível em http://tabnet.datasus.gov.br/cgi/tabcgi.exe?sih/cnv/miuf.def (Arquivo capturado em 12 de maio de 2010).

DELAUNOIS, B. et al. Uncovering plant-pathogen crosstalk through apoplastic proteomic studies. Frontiers in Plant Science, v. 5, p. 249, jan. 2014.

Dicionário Online de Português. Disponível em: <www.dicio.com.br>. Arquivo capturado em 18 de março de 2014.

DINARELLO, C. A. Immunological and inflammatory functions of the interleukin-1 family. Annual Review of Immunology, v. 27, p. 519-550, jan. 2009.

EAST, R. Nature Outlook Allergies- Introduction. Nature, v. 479, n. 7374, p. 4-5, 6 out. 2011.

EBELING, C. et al. Proteinase-activated receptor-2 promotes allergic sensitization to an inhaled antigen through a TNF-mediated pathway. The Journal of Immunology, v. 179, n. 5, p. 2910, 2007. 
EBERL, G. Close encounters of the second type. Nature, v. 464, n. April, 2010a.

EBERL, G. A new vision of immunity: homeostasis of the superorganism. Mucosal Immunology, v. 3, n. 5, p. 450-460, set. 2010b.

EISENBARTH, S. C. et al. Crucial role for the Nalp3 inflammasome in the immunostimulatory properties of aluminium adjuvants. Nature, v. 453, n. 7198, p. 1122-6, 19 jun. 2008.

EISENBARTH, S. C. Use and limitations of alum-based models of allergy. Clinical and Experimental Allergy: Journal of the British Society for Allergy and Clinical Immunology, v. 38, n. 10, p. 1572-1575, out. 2008.

FALLERONI, A. E.; SCHWARTZ, D. P. Immediate hypersensitivity to enzyme detergents. Lancet, v. 1, n. 7698, p. 548, 1971.

FAQUIM-MAURO, E. L.; JACYSYN, J. F.; MACEDO, M. S. Anaphylactic and nonanaphylactic murine IgG1 differ in their ability to bind to mast cells: relevance of proper glycosylation of the molecule. Immunobiology, v. 207, n. 3, p. 169-177, jan. 2003.

FERREIRA, A. H. et al. Purification, molecular cloning, and properties of a beta-glycosidase isolated from midgut lumen of Tenebrio molitor (Coleoptera) larvae. Insect Biochemistry and Molecular Biology, v. 31, n. 11, p. 1065-1076, out. 2001.

FINKELMAN, F. D. et al. Interleukin-4- and interleukin-13-mediated host protection against intestinal nematode parasites. Immunological Reviews, v. 201, p. 139-155, out. 2004.

FORT, M. et al. IL-25 induces IL-4, IL-5, and IL-13 and Th2-Associated Pathologies In Vivo. Immunity, v. 15, p. 985-995, 2001.

GALLI, S. J.; TSAI, M.; PILIPONSKY, A. M. The development of allergic inflammation. Nature, v. 454, n. 7203, p. 445-454, 24 jul. 2008.

GAO, Y. et al. Control of $\mathrm{T}$ helper 2 responses by transcription factor IRF4-dependent dendritic cells. Immunity, v. 39, n. 4, p. 722-732, 17 out. 2013.

GHIRINGHELLI, F. et al. Activation of the NLRP3 inflammasome in dendritic cells induces IL-1beta-dependent adaptive immunity against tumors. Nature Medicine, v. 15, n. 10, p. 1170-1178, 2009.

GOON GOH, F. et al. G-protein-dependent and -independent pathways regulate proteinaseactivated receptor-2 mediated p65 NFkappaB serine 536 phosphorylation in human keratinocytes. Cellular Signalling, v. 20, n. 7, p. 1267-1274, jul. 2008.

GOULD, H. J. et al. The biology of IGE and the basis of allergic disease. Annual Review of Immunology, v. 21, p. 579-628, jan. 2003.

HALIM, T. Y. F. et al. Retinoic-Acid-Receptor-Related Orphan Nuclear Receptor Alpha Is Required for Natural Helper Cell Development and Allergic Inflammation. Cell Immunity, v. 2, p. 463-474, 2012.

HALIM, T. Y. F. et al. Group 2 innate lymphoid cells are critical for the initiation of adaptive $\mathrm{T}$ helper 2 cell-mediated allergic lung inflammation. Immunity, v. 40, n. 3, p. 425-435, 20 mar. 2014. 
HAMMAD, $\mathrm{H}$. et al. House dust mite allergen induces asthma via Toll-like receptor 4 triggering of airway structural cells. Nature Medicine, v. 15, n. 4, p. 410-416, abr. 2009.

HAMMAD, H.; LAMBRECHT, B. N. Dendritic cells and epithelial cells: linking innate and adaptive immunity in asthma. Nature Reviews Immunology, v. 8, n. 3, p. 193-204, mar. 2008.

HERBERT, C. A. et al. Augmentation of permeability in the bronchial epithelium by the house dust mite allergen Der p1. American Journal of Respiratory Cell and Molecular Biology, v. 12, n. 4, p. 369-478, abr. 1995.

HERXHEIMER, H. The late bronchial reaction in induced asthma. International Archives of Allergy and Applied Immunology, v. 3, n. 4, p. 323-328, jan. 1952.

HOLGATE, S. T. et al. Anti-immunoglobulin E treatment with omalizumab in allergic diseases: an update on anti-inflammatory activity and clinical efficacy. Clinical and Experimental Allergy: Journal of the British Society for Allergy and Clinical Immunology, v. 35, n. 4, p. 408-416, abr. 2005.

HOLGATE, S. T.; POLOSA, R. Treatment strategies for allergy and asthma. Nature Reviews Immunology, v. 8, n. 3, p. 218-230, mar. 2008.

HOPFENSPIRGER, M. T. et al. Mycobacterial antigens attenuate late phase response, airway hyperresponsiveness, and bronchoalveolar lavage eosinophilia in a mouse model of bronchial asthma. International Immunopharmacology, v. 1, n. 9-10, p. 1743-1751, set. 2001.

HORNUNG, V. et al. Silica crystals and aluminum salts activate the NALP3 inflammasome through phagosomal destabilization. Nature Immunology, v. 9, n. 8, p. 847-856, ago. 2008.

IRVINE, A. D.; MCLEAN, W. H. I.; LEUNG, D. Y. M. Filaggrin mutations associated with skin and allergic diseases. The New England Journal of Medicine, v. 365, n. 14, p. 13151327, 6 out. 2011.

IWAMURA, C.; NAKAYAMA, T. Role of NKT cells in allergic asthma. Current Opinion in Immunology, v. 22, n. 6, p. 807-813, dez. 2010.

JACQUET, A. Interactions of airway epithelium with protease allergens in the allergic response. Clinical and Experimental Allergy : Journal of the British Society for Allergy and Clinical Immunology, v. 41, n. 3, p. 305-311, mar. 2011.

JANEWAY, C. Approaching the Asymptote? Evolution and Revolution in Immunology. Cold Spring Harbor symposia on quantitative ..., p. 1-13, 1989.

JONES, J. D. G.; DANGL, J. L. The plant immune system. Nature, v. 444, n. 7117, p. 323329, 16 nov. 2006.

JORDAN, M. B. et al. Promotion of B cell immune responses via an alum-induced myeloid cell population. Science (New York, N.Y.), v. 304, n. 5678, p. 1808-1810, 18 jun. 2004.

KAKKAR, R.; LEE, R. T. The IL-33/ST2 pathway: therapeutic target and novel biomarker. Nature reviews. Drug discovery, v. 7, n. 10, p. 827-840, out. 2008. 
KAMIJO, S. et al. IL-33-Mediated Innate Response and Adaptive Immune Cells Contribute to Maximum Responses of Protease Allergen-Induced Allergic Airway Inflammation. Journal of Immunology (Baltimore, Md. : 1950), n. 27, p. 1-11, 1 abr. 2013.

KATO, A. et al. TLR3- and Th2 cytokine-dependent production of thymic stromal lymphopoietin in human airway epithelial cells. Journal of Immunology (Baltimore, Md. : 1950), v. 179, n. 2, p. 1080-1087, 15 jul. 2007.

KATO, T. et al. Mite serine protease activates protease-activated receptor- 2 and induces cytokine release in human keratinocytes. Allergy, v. 64, n. 9, p. 1366-1374, set. 2009b.

KAWABATA, T. T.; BABCOCK, L. S.; HORN, P. A. Specific IgE and IgG1 responses to subtilisin Carlsberg (Alcalase) in mice: development of an intratracheal exposure model. Fundamental and Applied Toxicology : official journal of the Society of Toxicology, v. 29, n. 2, p. 238-243, fev. 1996.

KELLER, A. C. et al. Hierarchical suppression of asthma-like responses by mucosal tolerance. The Journal of Allergy and Clinical Immunology, v. 117, n. 2, p. 283-290, fev. 2006.

KHERADMAND, F. et al. A protease-activated pathway underlying Th cell type 2 activation and allergic lung disease. Journal of Immunology (Baltimore, Md. : 1950), v. 169, n. 10, p. 5904-5911, 15 nov. 2002.

KILEY, J.; SMITH, R.; NOEL, P. Asthma phenotypes. Current Opinion in Pulmonary Medicine, v. 13, n. 1, p. 19-23, jan. 2007.

KIM, H. Y.; DEKRUYFF, R. H.; UMETSU, D. T. The many paths to asthma: phenotype shaped by innate and adaptive immunity. Nature Immunology, v. 11, n. 7, p. 577-584, jul. 2010.

KLEIN WOLTERINK, R. G. J. et al. Pulmonary innate lymphoid cells are major producers of IL-5 and IL-13 in murine models of allergic asthma. European Journal of Immunology, v. 42, n. 5, p. 1106-1116, maio 2012.

KOUZAKI, H. et al. Proteases induce production of thymic stromal lymphopoietin by airway epithelial cells through protease-activated receptor-2. Journal of Immunology, v. 183, n. 2, p. $1427-1434,15$ jul. 2009.

KROEGER, K. M.; SULlIVAN, B. M.; LOCKSLEY, R. M. IL-18 and IL-33 elicit Th2 cytokines from basophils via a MyD88- and p38alpha-dependent pathway. Journal of Leukocyte Biology, v. 86, n. 4, p. 769-778, out. 2009.

KUHN, T. S. A Estrutura das Revoluções Científicas. [s.1.] Perspectiva, 2005. p. 260

KUMAMOTO, Y. et al. CD $301 b^{+}$dermal dendritic cells drive $\mathrm{T}$ helper 2 cell-mediated immunity. Immunity, v. 39, n. 4, p. 733-743, 17 out. 2013.

LAEMMLI, U. K. Cleavage of structural proteins during the assembly of the head of bacteriophage T4. Nature, v. 227, n. 5259, p. 680-685, 15 ago. 1970.

LARCHÉ, M. Update on the current status of peptide immunotherapy. The Journal of Allergy and Clinical Immunology, v. 119, n. 4, p. 906-909, abr. 2007. 
LEMIÈRE, C. et al. Isolated Late Asthmatic Reaction After Exposure to a high-molecularweight occupational agent, subtilisin. Chest, v. 110, n. 3, p. 823-824, 1996.

LI, N. et al. Particulate air pollutants and asthma. A paradigm for the role of oxidative stress in PM-induced adverse health effects. Clinical Immunology (Orlando, Fla.), v. 109, n. 3, p. 250-265, dez. 2003.

LICONA-LIMÓN, P. et al. TH2, allergy and group 2 innate lymphoid cells. Nature Immunology, v. 14, n. 6, p. 536-542, 20 maio 2013.

MAESTRELli, P. et al. Mechanisms of occupational asthma. The Journal of Allergy and Clinical Immunology, v. 123, n. 3, p. 531-542; quiz 543-4, mar. 2009.

MAJNO, G. The Healing Hand: Man and Wound in the Ancient World. [s.1.] Harvard University Press, 1991. p. 571

MANDLER, R. et al. IL-4 induction of IgE class switching by lipopolysaccharide-activated murine B cells occurs predominantly through sequential switching. Journal of Immunology (Baltimore, Md. : 1950), v. 150, n. 2, p. 407-418, 15 jan. 1993.

MARICHAL, T. et al. DNA released from dying host cells mediates aluminum adjuvant activity. Nature Medicine, v. 17, n. 8, p. 996-1002, 17 ago. 2011.

MARKARYAN, A. et al. Purification and characterization of an elastinolytic metalloprotease from Aspergillus fumigatus and immunoelectron microscopic evidence of secretion of this enzyme by the fungus invading the murine lung. Infection and Immunity, v. 62, n. 6, p. 2149-2157, jun. 1994.

MAYOR, A. et al. Gout-associated uric acid crystals activate the NALP3 inflammasome. Nature Letter, v. 1, p. 1-5, 2006.

MEDOFF, B. D.; THOMAS, S. Y.; LUSTER, A. D. T cell trafficking in allergic asthma: the ins and outs. Annual Review of Immunology, v. 26, p. 205-232, jan. 2008.

MEDZHITOV, R. Origin and physiological roles of inflammation. Nature, v. 454, n. 7203, p. 428-435, 24 jul. 2008 b.

MEDZHITOV, R. Inflammation 2010: new adventures of an old flame. Cell, v. 140, n. 6, p. 771-776, 19 mar. 2010.

MOHRS, M. et al. Analysis of type 2 immunity in vivo with a bicistronic IL-4 reporter. Immunity, v. 15, n. 2, p. 303-311, ago. 2001.

MORO, K. et al. Innate production of $\mathrm{T}(\mathrm{H}) 2$ cytokines by adipose tissue-associated cKit(+)Sca-1(+) lymphoid cells. Nature, v. 463, n. 7280, p. 540-544, 28 jan. 2010.

MOSMANN, T. R. et al. Two types of murine helper T cell clone. I. Definition according to profiles of lymphokine activities and secreted proteins. Journal of Immunology (Baltimore, Md. : 1950), v. 136, n. 7, p. 2348-2357, 1 abr. 1986.

MOUSSION, C.; ORTEGA, N.; GIRARD, J.-P. The IL-1-like cytokine IL-33 is constitutively expressed in the nucleus of endothelial cells and epithelial cells in vivo: a novel “alarmin"? PloS One, v. 3, n. 10, p. e3331, jan. 2008. 
NATHAN, A. T. et al. Innate immune responses of airway epithelium to house dust mite are mediated through beta-glucan-dependent pathways. The Journal of Allergy and Clinical Immunology, v. 123, n. 3, p. 612-618, mar. 2009.

NEILL, D. R. et al. Nuocytes represent a new innate effector leukocyte that mediates type-2 immunity. Nature, v. 464, n. 7293, p. 1367-1370, 29 abr. 2010.

NOVEY, H.; MARCHIOLI, L.; SOKOL, W. Papain-induced asthma-physiological and immunological features. Journal of Allergy and Clinical Immunology, 1979.

O'BYRNE, P. M.; GAUVREAU, G. M.; BRANNAN, J. D. Provoked models of asthma: what have we learnt? Clinical and Experimental Allergy : Journal of the British Society for Allergy and Clinical Immunology, v. 39, n. 2, p. 181-192, fev. 2009.

OBOKI, K. et al. IL-33 is a crucial amplifier of innate rather than acquired immunity. Proceedings of the National Academy of Sciences of the United States of America, v. 107, n. 43, p. 18581-18586, 26 out. 2010.

OKADA, H. et al. The "hygiene hypothesis" for autoimmune and allergic diseases: an update. Clinical and Experimental Immunology, v. 160, n. 1, p. 1-9, abr. 2010.

OLIPHANT, C. J.; BARLOW, J. L.; MCKENZIE, A. N. J. Insights into the initiation of type 2 immune responses. Immunology, v. 134, n. 4, p. 378-385, dez. 2011.

ORTEGA, E.; SCHNEIDER, H.; PECHT, I. Possible interactions between the Fc epsilon receptor and a novel mast cell function-associated antigen. International Immunology, v. 3, n. 4, p. 333-342, abr. 1991.

PAGE, K. et al. Mucosal sensitization to German cockroach involves protease-activated receptor-2. Respiratory Research, v. 11, p. 62, jan. 2010.

PAGE, K.; STRUNK, V. S.; HERSHENSON, M. B. Cockroach proteases increase IL-8 expression in human bronchial epithelial cells via activation of protease-activated receptor (PAR)-2 and extracellular-signal-regulated kinase. The Journal of Allergy and Clinical Immunology, v. 112, n. 6, p. 1112-1118, dez. 2003.

PAL, S. K.; PEON, J.; ZEWAIL, A. H. Biological water at the protein surface: dynamical solvation probed directly with femtosecond resolution. Proceedings of the National Academy of Sciences of the United States of America, v. 99, n. 4, p. 1763-1768, 19 fev. 2002.

PALM, N. W. et al. Bee venom phospholipase A2 induces a primary type 2 response that is dependent on the receptor ST2 and confers protective immunity. Immunity, v. 39, n. 5, p. 976-985, 14 nov. 2013.

PALM, N. W.; ROSENSTEIN, R. K.; MEDZHITOV, R. Allergic host defences. Nature, v. 484, n. 7395, p. 465-472, 25 abr. 2012.

PALMQVIST, M. et al. Inhaled dry-powder formoterol and salmeterol in asthmatic patients: onset of action, duration of effect and potency. The European Respiratory Journal, v. 10, n. 11, p. 2484-2489, nov. 1997.

PARNES, O. "Trouble from within": allergy, autoimmunity, and pathology in the first half of the twentieth century. Studies in History and Philosophy of Science Part C: Studies in 
History and Philosophy of Biological and Biomedical Sciences, v. 34, n. 3, p. 425-454, set. 2003.

PAUL, W. E.; ZHU, J. How are T(H)2-type immune responses initiated and amplified? Nature reviews. Immunology, v. 10, n. 4, p. 225-235, abr. 2010.

PAWANKAR, R.; CANONICA, G. White Book on Allergy. WI: World Allergy, 2011.

PEPPERKOK, R.; ELLENBERG, J. High-throughput fluorescence microscopy for systems biology. Nature reviews. Molecular Cell Biology, v. 7, n. 9, p. 690-696, set. 2006.

PETROVSKY, N.; AGUILAR, J. C. Vaccine adjuvants: current state and future trends. Immunology and Cell Biology, v. 82, n. 5, p. 488-96, out. 2004.

PICHAVANT, M. et al. Ozone exposure in a mouse model induces airway hyperreactivity that requires the presence of natural killer T cells and IL-17. The Journal of Experimental Medicine, v. 205, n. 2, p. 385-393, 18 fev. 2008.

PLATTS-MILLS, T. A. E. et al. Pro: The evidence for a causal role of dust mites in asthma. American Journal of Respiratory and Critical Care Medicine, v. 180, n. 2, p. 109-113; discussion 120-1, 15 jul. 2009.

POLOSA, R. Critical appraisal of antileukotriene use in asthma management. Current Opinion in Pulmonary Medicine, v. 13, n. 1, p. 24-30, jan. 2007.

PRICE, A. E. et al. Systemically dispersed innate IL-13-expressing cells in type 2 immunity. Proceedings of the National Academy of Sciences of the United States of America, v. 107, n. 25, p. 11489-11494, 22 jun. 2010.

PRICE, D. J.; GUNSALUS, J. R.; AVRUCH, J. Insulin activates a 70-kDa S6 kinase through serine/threonine-specific phosphorylation of the enzyme polypeptide. Proceedings of the National Academy of Sciences of the United States of America, v. 87, n. 20, p. 7944-7948, out. 1990.

PROFET, M. The function of allergy: immunological defense against toxins. The Quarterly Review of Biology, v. 66, n. 1, p. 23-62, mar. 1991.

RABINOVITCH, M.; MANEJIAS, R.; NUSSENZWEIG, V. Selective phagocytic paralysis induced by immobilized immune complexes. The Journal of Experimental Medicine, v. 142, n. 4, p. 827, 1975.

RALLABHANDI, P. et al. Analysis of proteinase-activated receptor 2 and TLR4 signal transduction: a novel paradigm for receptor cooperativity. The Journal of Biological Chemistry, v. 283, n. 36, p. 24314-24325, 5 set. 2008.

RAMADAS, R. A. et al. IL-1 Receptor antagonist as a positional candidate gene in a murine model of allergic asthma. Immunogenetics, v. 58, n. 10, p. 851-855, out. 2006.

RAMESH, M. V; SIRAKOVA, T. D.; KOLATTUKUDY, P. E. Cloning and characterization of the cDNAs and genes (mep20) encoding homologous metalloproteinases from Aspergillus flavus and A. fumigatus. Gene, v. 165, n. 1, p. 121-125, 7 nov. 1995.

RAMOS, G. Inflammation as an Animal Development Phenomenon. Clinical and Developmental Immunology, v. 2012, 2011. 
RAMOS, R. N. et al. Monocyte-derived dendritic cells from breast cancer patients are biased to induce CD4+CD25+Foxp3+ regulatory T cells. Journal of Leukocyte Biology, v. 92, n. September, p. 1-10, 25 maio 2012.

REED, C. E.; KITA, H. The role of protease activation of inflammation in allergic respiratory diseases. The Journal of Allergy and Clinical Immunology, v. 114, n. 5, p. 997-1008; quiz 1009, nov. 2004.

RING, J. Terminology of allergic phenomena. Chemical Immunology and Allergy, v. 100, p. 46-52, jan. 2014.

RING, P. C. et al. The 18-kDa form of cat allergen Felis domesticus 1 (Fel d 1) is associated with gelatin- and fibronectin-degrading activity. Clinical and Experimental Allergy: Journal of the British Society for Allergy and Clinical Immunology, v. 30, n. 8, p. 10851096, ago. 2000.

RITZ, H. L. et al. Respiratory and immunological responses of guinea pigs to enzymecontaining detergents: a comparison of intratracheal and inhalation modes of exposure. Fundamental and Applied Toxicology : Official Journal of the Society of Toxicology, v. 21, n. 1, p. 31-37, jul. 1993.

ROBAYS, L. J. et al. Between a cough and a wheeze: dendritic cells at the nexus of tobacco smoke-induced allergic airway sensitization. Mucosal Immunology, v. 2, n. 3, p. 206-219, 4 maio 2009.

ROBINSON, D. S. et al. Predominant TH2-like bronchoalveolar T-lymphocyte population in atopic asthma. The New England Journal of Medicine, v. 326, n. 5, p. 298-304, 30 jan. 1992.

ROBINSON, M. K. et al. Specific antibody responses to subtilisin Carlsberg (Alcalase) in mice: development of an intranasal exposure model. Fundamental and Applied Toxicology : Official Journal of the Society of Toxicology, v. 34, n. 1, p. 15-24, nov. 1996.

ROCHE, N. et al. Dermatophagoides pteronyssinus and bioelectric properties of airway epithelium: role of cysteine proteases. The European Respiratory Journal, v. 16, n. 2, p. 309-315, ago. 2000.

ROTHENBERG, M. E.; HOGAN, S. P. The eosinophil. Annual Review of Immunology, v. 24, p. 147-174, jan. 2006.

RUNSWICK, S. et al. Pollen proteolytic enzymes degrade tight junctions. Respirology (Carlton, Vic.), v. 12, n. 6, p. 834-842, nov. 2007.

RUSSO, M. et al. Suppression of asthma-like responses in different mouse strains by oral tolerance. American Journal of Respiratory Cell and Molecular Biology, v. 24, n. 5, p. 518-526, maio 2001.

SAENZ, S. A.; TAYLOR, B. C.; ARTIS, D. Welcome to the neighborhood: epithelial cellderived cytokines license innate and adaptive immune responses at mucosal sites. Immunological Reviews, v. 226, p. 172-190, dez. 2008.

SARLO, K. et al. Respiratory Allergenicity of Detergent Enzymes in the Guinea Pig Intratracheal Test: Association with Sensitization of Occupationally Exposed Individuals. Toxicological Sciences, v. 39, n. 1, p. 44, 1997. 
SAUNDERS, K. B. Origin of the word "asthma". Thorax - An International Journal of Respiratory Medicine, v.48(6), p. 647, jun. 1993.

SCALFONE, L. K. et al. Participation of MyD88 and interleukin-33 as innate drivers of Th2 immunity to Trichinella spiralis. Infection and Immunity, v. 81, n. 4, p. 1354-1363, abr. 2013.

SCHECHTER, N. M. et al. Reaction of mast cell proteases tryptase and chymase with protease activated receptors (PARs) on keratinocytes and fibroblasts. Journal of Cellular Physiology, v. 176, n. 2, p. 365-373, ago. 1998.

SCHMIDLIN, F. et al. Protease-activated receptor 2 mediates eosinophil infiltration and hyperreactivity in allergic inflammation of the airway. Journal of Immunology (Baltimore, Md. : 1950), v. 169, n. 9, p. 5315-5321, 1 nov. 2002.

SCHMIDT, M. et al. Crucial role for human Toll-like receptor 4 in the development of contact allergy to nickel. Nature Immunology, v. 11, n. 9, p. 814-819, out. 2010.

SCHMITZ, J. et al. IL-33, an interleukin-1-like cytokine that signals via the IL-1 receptorrelated protein ST2 and induces T helper type 2-associated cytokines. Immunity, v. 23, n. 5, p. 479-490, nov. 2005.

SCHWEIGERT, M. K.; MACKENZIE, D. P.; SARLO, K. Occupational asthma and allergy associated with the use of enzymes in the detergent industry-a review of the epidemiology, toxicology and methods of prevention. Clinical and Experimental Allergy, v. 30, n. 11, p. 1511-1518, nov. 2000.

SERHAN, C. N.; SAVILL, J. Resolution of inflammation: the beginning programs the end. Nature Immunology, v. 6, n. 12, p. 1191-1197, dez. 2005.

SHAKIB, F.; GHAEMMAGHAMI, A. M.; SEWELL, H. F. The molecular basis of allergenicity. Trends in Immunology, v. 29, n. 12, p. 633-642, dez. 2008.

SHPACOVITCH, V. et al. Protease-activated receptors: novel PARtners in innate immunity. Trends in Immunology, v. 28, n. 12, p. 541-550, dez. 2007a.

SHPACOVITCH, V. M. et al. Agonists of proteinase-activated receptor-2 affect transendothelial migration and apoptosis of human neutrophils. Experimental Dermatology, v. 16, n. 10 , p. $799-806$, out. 2007 b.

SILVERSTEIN, A. M. Darwinism and immunology: from Metchnikoff to Burnet. Nature Immunology, v. 4, n. 1, p. 3-6, jan. 2003.

SILVERSTEIN, A. M. Paul Ehrlich, archives and the history of immunology. Nature Immunology, v. 6, n. 7, p. 639, jul. 2005.

SILVERSTEIN, A. M. A History of Immunology. 2nd. ed. [s.1.] Academic Press, 2009. p. 552

SIMONS, F. E. R. Anaphylaxis in infants: can recognition and management be improved? The Journal of Allergy and Clinical Immunology, v. 120, n. 3, p. 537-540, set. 2007.

SIRACUSA, M. C. et al. Basophils and allergic inflammation. The Journal of allergy and clinical immunology, v. 132, n. 4, p. 789-801; quiz 788, out. 2013. 
SLY, P. D.; KUSEL, M.; HOLT, P. G. Do early-life viral infections cause asthma? The Journal of Allergy and Clinical Immunology, v. 125, n. 6, p. 1202-1205, jun. 2010.

SMITH, P. K. et al. Measurement of Protein Using Bicinchoninic Acid. Analytical Biochemistry, v. 85, p. 76-85, 1985.

SOKOL, C. L. et al. A mechanism for the initiation of allergen-induced T helper type 2 responses. Nature Immunology, v. 9, n. 3, p. 310-318, mar. 2008.

SOKOL, C. L.; MEDZHITOV, R. Emerging functions of basophils in protective and allergic immune responses. Mucosal Immunology, v. 3, n. 2, p. 129-137, mar. 2010.

SOUMELIS, V. et al. Human epithelial cells trigger dendritic cell mediated allergic inflammation by producing TSLP. Nature Immunology, v. 3, n. 7, p. 673-680, jul. 2002.

SPITS, H. et al. Innate lymphoid cells - a proposal for uniform nomenclature. Nature Reviews Immunology, v. 13, n. 2, p. 145-149, 7 jan. 2013.

SPITS, H.; CUPEDO, T. Innate lymphoid cells: emerging insights in development, lineage relationships, and function. Annual Review of Immunology, v. 30, p. 647-675, jan. 2012.

SPOONER, C. J. et al. Specification of type 2 innate lymphocytes by the transcriptional determinant Gfi1. Nature Immunology, v. 14, n. 12, p. 1229-1236, dez. 2013.

STEINHOFF, M. et al. Proteinase-activated receptor-2 mediates itch: a novel pathway for pruritus in human skin. The Journal of Neuroscience : the Official journal of the Society for Neuroscience, v. 23, n. 15, p. 6176-6180, 16 jul. 2003.

STRACHAN, D. P. Hay fever, hygiene, and household size. BMJ (Clinical research ed.), v. 299, n. 6710, p. 1259-1260, 18 nov. 1989.

SUDHA, V. T.; ARORA, N.; SINGH, B. P. Serine protease activity of Per a 10 augments allergen-induced airway inflammation in a mouse model. European Journal of Clinical Investigation, v. 39, n. 6, p. 507-516, jun. 2009.

SUN, G. et al. Interaction of mite allergens Der p3 and Der p9 with protease-activated receptor-2 expressed by lung epithelial cells. Journal of Immunology (Baltimore, Md. : 1950), v. 167, n. 2, p. 1014-1021, 15 jul. 2001.

SUTHERLAND, E. R. Obesity and asthma. Immunology and Allergy Clinics of North America, v. 28, n. 3, p. 589-602, ix, ago. 2008.

TAUBER, A. I. Metchnikoff and the phagocytosis theory. Nature Reviews Molecular cell Biology, v. 4, n. 11, p. 897-901, nov. 2003.

TAUBER, A. I.; CHERNYAK, L. Metchnikoff and the Origins of Immunology : From Metaphor to Theory. [s.1.] Oxford University Press, USA, 1991. p. 280

TEMKIN, V. et al. Tryptase activates the mitogen-activated protein kinase/activator protein-1 pathway in human peripheral blood eosinophils, causing cytokine production and release. Journal of Immunology (Baltimore, Md. : 1950), v. 169, n. 5, p. 2662-2669, 1 set. 2002.

TOWNSEND, M. J. et al. T1/ST2-deficient mice demonstrate the importance of T1/ST2 in developing primary $\mathrm{T}$ helper cell type 2 responses. The Journal of Experimental Medicine, v. 191, n. 6, p. 1069-1076, 20 mar. 2000. 
TROMPETTE, A. et al. Allergenicity resulting from functional mimicry of a Toll-like receptor complex protein. Nature, v. 457, n. 7229, p. 585-588, 29 jan. 2009.

UBL, J. J. et al. Human bronchial epithelial cells express PAR-2 with different sensitivity to thermolysin. American Journal of Physiology. Lung cellular and Molecular Physiology, v. 282, n. 6, p. L1339-1348, jun. 2002.

VAZ, N. Sobre a Imunidade Inata. Disponível em: <http://blogdasbi.blogspot.com.br/2011/11/544x376-normal-0-false-false-false-en.html>.

VAZ, N. et al. Onde está o Organismo? [s.1.] Editora da UFSC, 2011.

VAZ, N. M. Evolution and conservation of immunological activity. Brazilian Journal of Medical and Biological Research $=$ Revista brasileira de pesquisas médicas e biológicas / Sociedade Brasileira de Biofísica ... [et al.], v. 39, n. 12, p. 1521-1524, dez. 2006.

VAZ, N. M.; VARELA, F. J. Self and non-sense: an organism-centered approach to immunology. Medical Hypotheses, v. 4, n. 3, p. 231-267, 1978.

WALTON, S. F. et al. Increased allergic immune response to Sarcoptes scabiei antigens in crusted versus ordinary scabies. Clinical and Vaccine Immunology : CVI, v. 17, n. 9, p. $1428-1438$, set. 2010.

WANG, W. et al. Potential therapeutic targets for steroid-resistant asthma. Current Drug Targets, v. 11, n. 8, p. 957-970, ago. 2010.

WANG, X. S. et al. PGE suppresses excessive anti-IgE induced cysteinyl leucotrienes production in mast cells of patients with aspirin exacerbated respiratory disease. Allergy, v. 62, n. 6, p. 620-627, jun. 2007.

WILLART, M. A M. et al. Interleukin-1 $\alpha$ controls allergic sensitization to inhaled house dust mite via the epithelial release of GM-CSF and IL-33. The Journal of Experimental Medicine, 16 jul. 2012.

WILLIAMS, C. M.; GALLI, S. J. Mast cells can amplify airway reactivity and features of chronic inflammation in an asthma model in mice. The Journal of Experimental Medicine, v. 192, n. 3, p. 455-462, 7 ago. 2000.

WILLS-KARP, M. et al. New insights into innate immune mechanisms underlying allergenicity. Mucosal Immunology, v. 3, n. 2, p. 104-110, mar. 2010.

WILSON, D. H. et al. Trends in asthma prevalence and population changes in South Australia, 1990-2003. The Medical Journal of Australia, v. 184, n. 5, p. 226-229, 6 mar. 2006.

WILSON, S. R. et al. The Epithelial Cell-Derived Atopic Dermatitis Cytokine TSLP Activates Neurons to Induce Itch. Cell, v. 155, n. 2, p. 285-295, 10 out. 2013.

WU, L. C.; ZARRIN, A. A. The production and regulation of IgE by the immune system. Nature Reviews Immunology, v. 14, n. 4, p. 247-259, abr. 2014.

YING, S. et al. Thymic stromal lymphopoietin expression is increased in asthmatic airways and correlates with expression of Th2-attracting chemokines and disease severity. Journal of Immunology (Baltimore, Md. : 1950), v. 174, n. 12, p. 8183-8190, 15 jun. 2005. 
YOKOTA, Y. et al. Development of peripheral lymphoid organs and natural killer cells depends on the helix-loop-helix inhibitor Id2. Nature, v. 397, n. 6721, p. 702-706, 25 fev. 1999.

ZAISS, D. M. et al. Amphiregulin, a TH2 cytokine enhancing resistance to nematodes. Science (New York, N.Y.), v. 314, n. 5806, p. 1746, 15 dez. 2006.

ZHENG, W.; FLAVELL, R. A. The transcription factor GATA-3 is necessary and sufficient for Th2 cytokine gene expression in CD4 T cells. Cell, v. 89, n. 4, p. 587-596, 16 maio 1997.

ZIEGLER, E. Lehrbuch der allgemeinen Pathologie und der pathologischen Anatomie. 6th. ed. [s.1.] Рипол Классик, 1889.

ZIPFEL, C.; FELIX, G. Plants and animals: a different taste for microbes? Current Opinion in Plant Biology, v. 8, n. 4, p. 353-60, ago. 2005.

ZWEIFACH, B. W. The Inflammatory Process. 2nd ed, Volume 1. 1974. 


\section{APÊNDICE A}

\section{Artigos publicados ou submetidos durante o período do doutorado}

- "Serine protease subtilisin promotes allergic lung inflammation via protease-activated receptor 2, IL-33 receptor ST2 and MyD88 signaling”. Florsheim, E.; Bragatto, I.; Faustino, L.; Gomes, E.; Yu, S.; Medzhitov, R.; Russo, M. submetido em 2014.

- "Tumor necrosis factor-related apoptosis-inducing ligand mediates the resolution of allergic airway inflammation induced by chronic allergen inhalation". Faustino, L.; Fonseca DM.; Florsheim, E.; Lepique, AP.; Faquim-Mauro, E.; Silva, JS.; Yagita, H.; Russo, M. Mucosal Immunology 2014.

- "Bee venom phospholipase A2 induces a primary type 2 response that is dependent on the receptor ST2 and confers protective immunity". Palm, NW.; Rosenstein, RK.; Yu, S.; Schenten, D.; Florsheim, E.; Medzhitov, R. Immunity 2013.

- "Lipids are required for the development of Brazil nut allergy: the role of mouse and human iNKT cells". Mirotti, L.; Florsheim, E.; Rundqvist, L.; Larsson, G.; Spinozzi, F.; Leite-deMoraes, M.; Russo, M.; Alcocer, M. Allergy, 2013.

- "Endotoxin exposure during sensitization to Blomia tropicalis allergens shifts TH2 immunity towards a TH17-mediated airway neutrophilic inflammation: role of TLR4 and TLR2”. Barboza R.; Câmara NO.; Gomes E.; Sá-Nunes A.; Florsheim E.; Mirotti L.; Labrada A.; Alcântara-Neves NM.; Russo M. Plos One 2013.

- "Regulatory T cells migrate to airways via CCR4 and attenuate the severity of allergic airway inflammation". Faustino, L.; Fonseca, DM.; Takenaka, MC.; Mirotti, L.; Florsheim, E.; Guereschi, MG.; Silva, JS.; Basso, A.; Russo, M. Journal of Immunology, 2013.

- "Role of $m 2$ muscarinic receptor in the airway response to metacholine of mice selected for minimal or maximal acute inflammatory response". Castro, JM.; Resende, RR.; Mirotti, L.; Florsheim, E.; Albuquerque, L.; Lino-dos-Santos-Franco, A.; Gomes, E.; Lima, W.; de Franco, M.; Ribeiro, O.; Russo, M. Biomed Research International, 2013. 


\section{APÊNDICE B}

\section{Artigo publicado na SBI na rede: “O Hajj da imunologia atual: imunidade Th2"}

\author{
\%\& $0 *$ !+, -!. /!\&010234' 50\&, 6 \\ $78^{*} \& 450(9$ :!; /\&* !10!=>? ?!
}

!

\section{O Hajj da imunologia atual: imunidade $\mathbf{T}_{\mathrm{H}} 2$}

O Hajj, a peregrinação à Meca santuário mais sagrado do Islã- no décimo segundo mês islâmico, é um dos pilares que sustentam e estruturam a vida de um muçulmano [1]. Todo ano, milhares de religiosos do Islamismo se concentram nesta meta e realizam o Hajj ao menos uma vez na vida. $O$ que a Imunologia tem a ver com isto? Ora, a meu ver, os cientistas de um modo geral estão sempre numa peregrinação em comum, na 'rota para a ciência normal', como escreve Thomas Kuhn em "A Estrutura das Revoluções Científicas" [2]. Dentro deste enfoque é que gostaria de apresentar a Meca recente da Imunologia: a questão da imunidade do tipo $\mathrm{T}_{\mathrm{H}} 2$.

No ano passado houve um aumento quase exponencial no número de artigos publicados que investigaram mecanismos das respostas $\mathrm{T}_{\mathrm{H}} 2$. Quase 25 anos após o trabalho de Mosmann e Coffman [3], o subtipo de linfócito $\mathrm{T}$ auxiliador $2 \quad\left(\mathrm{~T}_{\mathrm{H}} 2\right)$ começa a ser extensivamente estudado. Já naquela época ficou evidente a participação dessas células em respostas alérgicas e infecções por helmintos. No entanto, os mecanismos que levam ao início dessa resposta e como ela é mantida e amplificada era desconhecido. A partir desta última década este paromana começou a mudar e as descobertas desde então forneceram uma vasta ideia de como essa imunidade é gerada e que tipos de células participam da diferenciação de linfócitos $\mathrm{T} \mathrm{CD} 4^{+}$naïve para $\mathrm{T}_{\mathrm{H}} 2$. Neste ano que passou, em particular, o universo das respostas imunes $\mathrm{T}_{\mathrm{H}} 2$ se expandiu e se encontra, atualmente, na Era das Luzes da Imunologia contemporânea.

Questão de ordem: como as respostas TH2 são iniciadas?
Para resumir a estória, tudo começou com a publicação do grupo do Ruslan Medzhitov em dezembro de 2007 [4]. A partir deste trabalho, tudo que se refere à imunidade $\mathrm{T}_{\mathrm{H}} 2$ parece ter mudado. $\mathrm{O}$ grupo chamou a atenção para a possibilidade dos basófilos poderem responder diretamente ao alérgeno e produzir citocinas de padrão $\mathrm{T}_{\mathrm{H}} 2$, em modelo de alergia induzida por protease. Isto já foi o suficiente para causar grande comoção na comunidade científica, já que alterava o 'dogma central' da Imunologia, no qual as células dendríticas (DCs) é que possuem a característica única de mediar a passagem da resposta inata para a adaptativa e, portanto seriam essenciais em qualquer situação.

Não demorou muito para os imunologistas perceberem a importância daquele achado e em maio de 2009 três artigos de grupos diferentes (David Artis, Kenji Nakanishi e, de novo, Ruslan Medzhitov) e na mesma edição da Nature tentaram desvendar o mistério. Novamente, apontaram os basófilos como os principais responsáveis pelo início de uma resposta $\mathrm{T}_{\mathrm{H}} 2$, usando modelo de infecção por helmintos ou de alergia à protease [5,6,7]. A solução para o problema estava no fato de que esses granulócitos circulantes poderiam migrar para os linfonodos e agir como legítimas células apresentadoras (APCs) ao englobar e processar antígenos, expressar moléculas co-estimuladoras e produzir citocinas como IL-4 e TSLP (thymic stromal Iymphopoietin) para o desenvolvimento da resposta $\mathrm{T}_{\mathrm{H}} 2$.

No ano seguinte, em 2010, mais um trabalho impactante publicado no Journal of Experimental Medicine. o grupo do Bart Lambrecht sugeriu, ao contrário dos anteriores, que no modelo de alergia a HDM (ácaros presentes na poeira doméstica) os basófilos não seriam necessários para ativação de $\mathrm{T}_{\mathrm{H}} 2$ [8]. Ainda, forneceu dados consistentes de que neste modelo um subgrupo de DCs que expressam FceRI é que seria responsável e suficiente para a polarização da imunidade $\mathrm{T}_{\mathrm{H}} 2$. 
Por fim e para completar o cenário, outros três trabalhos da Nature Letters do ano passado confirmam a atuação essencial de células da imunidade inata no desenvolvimento de respostas $\mathrm{T}_{\mathrm{H}} 2$ (Shigeo Koyasu, Andrew McKenzie e David Artis). O primeiro destes três trabalhos identificou pequenos agrupamentos de células associadas ao tecido adiposo do mesentério, que se mostraram fundamentais na produção de muco em resposta à infecção helmíntica e, pela expressão de IL-4 e IL-13 e indução de imunidade $\mathrm{T}_{\mathrm{H}} 2$, foram chamadas Natural Helper Cells, NHC [9]. O segundo grupo verificou a migração intensa de células produtoras de IL-13 em resposta à infecção pelo mesmo helminto (N. brasiliensis) aos linfonodos drenantes do intestino e nomeou estas células de nuócitos, baseado na décima terceira letra do alfabeto grego, nu [10]. Finalmente, o grupo de David Artis mostrou de maneira semelhante que em resposta a IL-25 e IL33 metade das células inatas que expandem em número expressam tanto IL4 como também marcadores de progenitores multipotentes de leucócitos [11]. Eles resolveram chamar estas células de progenitores do tipo 2 multipotentes $\left(\mathrm{MPP}^{\mathrm{type2}}\right.$ ), pois verificaram a capacidade delas em gerar outras células da imunidade inata como mastócitos, basófilos e macrófagos. O que nos resta saber é se esses três tipos celulares descritos são relacionados, se as células MPP $^{\text {type2 }}$ poderiam originar as NHC ou nuócitos. Esses últimos artigos ainda confirmam a importância das células do epitélio intestinal em resposta a helmintos, pela produção IL-25 (IL-17F) e IL-33, que promovem diferenciação e ativação de linfócitos $\mathrm{T}_{\mathrm{H}} 2$.

\section{Depois da largada: Sinalização e Migração}

Independente da célula que inicie a resposta $T_{H} 2$ - pela produção de citocinas específicas e migração aos linfonodos- são necessárias mais etapas no processo de formação da resposta per se. Primeiro, como um linfócito $\mathrm{T}$ naïve se diferencia em $\mathrm{T}_{\mathrm{H}} 2$ e não em outros subtipos?
Como já mencionado anteriormente, os linfócitos $\mathrm{CD}^{+} \mathrm{T}_{\mathrm{H}} 2$ representam a principal estratégia de interação com parasitas extracelulares como os "vermes" e também são a causa do desenvolvimento de doenças alérgicas. Estas células podem ativar linfócitos B, que produzem o isotipo IgE (via IL-4), induzir a ativação alternativa de macrófagos (IL-4/IL-13), recrutar eosinófilos (IL-5) e ativar mastócitos (IL9). Resumidamente, mas não definitivamente, a diferenciação para esse subtipo de linfócito $\mathrm{CD}^{+}$requer ligação pelo TCR e sinalização mediada por IL-4, que leva ao recrutamento de STAT6 e, por sua vez, induz a ativação do fator de transcrição GATA3. Parece que a sinalização IL-2/STAT5 também é bastante importante para a diferenciação desses linfócitos em um padrão $\mathrm{T}_{\mathrm{H}} 2$ tanto in vitro como in vivo [12]. Ainda, para o total comprometimento de um linfócito $\mathrm{T}_{\mathrm{H}} 2$ é necessária a supressão de destinos alternativos, por exemplo, inibição da expressão de STAT4 ou T-bet, que levariam à diferenciação para $\mathrm{T}_{\mathrm{H}} 1$. Ao contrário dos modelos in vitro nos quais a IL-4 é absolutamente fundamental para diferenciação $\mathrm{T}_{\mathrm{H}} 2$, outras citocinas como TSLP, IL-25 e IL-33 podem influenciar essa resposta in vivo. Portanto, os mecanismos de regulação da transcrição para polarização $\mathrm{T}_{\mathrm{H}} 2$ precisam ser melhor entendidos em modelos in vivo.

Como último e rápido comentário, precisamos lembrar que esses linfócitos $\mathrm{T}_{\mathrm{H}} 2$ recém-convertidos precisam achar seu caminho. Isto é basicamente função das quimiocinas expressas nos locais de inflamação que interagem com seus receptores acoplados à proteína $G$ (GPCRs), localizados nos linfócitos. Para cada tipo de resposta imune e tecidos do organismo, existe um conjunto específico e talvez até redundante, desse par quimiocina-receptor. Na semana passada saiu um artigo na Nature justamente sobre o que nos interessa agora: quimiocinas e resposta $\mathrm{T}_{\mathrm{H}} 2$. Este trabalho foi conduzido pelo grupo do Andrew Luster e também pelo nosso colega brasileiro Sérgio Lira [13]. Eles analisaram as funções da CCL8, uma quimiocina do tipo -CC e subfamília 
MCP (monocyte chemoattactant proteins), em modelo de dermatite atópica, uma doença alérgica crônica da pele. $\mathrm{O}$ grupo mostra pela primeira vez que esta quimiocina é constitutivamente expressa na pele e em linfonodos de camundongos e que sua função é a de atrair linfócitos $\mathrm{T}_{\mathrm{H}} 2$ altamente polarizados e ativados (com alta expressão de Gata-3), via receptor CCR8. Um dos pontos mais interessantes do trabalho é a demonstração da heterogeneidade das populações de linfócitos $\mathrm{T}_{\mathrm{H}} 2$, já que linfócitos $\mathrm{T}_{\mathrm{H}} 2$ $\mathrm{CCR}^{+}{ }^{+}$expressam mais IL-5, OX40 e TNF, ao contrário de linfócitos $\mathrm{T}_{\mathrm{H}} 2$ $\mathrm{CCR} 4^{+}$, que expressam mais IL-4. Por fim, mostram que a expressão desse receptor CCR8, mas não de CCR4, é fundamental para o desenvolvimento da dermatite atópica. Vale a pena ler o trabalho na íntegra.

\section{"Minha força é não ter encontrado resposta para nada". E. M. Cioran}

No começo deste texto, disse que de uns anos para cá a área de conhecimento no que refere à imunidade $\mathrm{T}_{\mathrm{H}} 2$ havia avançado bastante. Mas, à primeira vista, parece que tudo só se complicou. Agora temos diversos modelos para investigar a participação de várias células da imunidade inata que levarão à ativação de linfócitos $\mathrm{T}_{\mathrm{H}} 2$ por uma sinalização não muito estabelecida $\mathrm{e}$, ainda, mal sabemos como esses linfócitos chegam lá! De qualquer maneira, podemos perceber que esse tipo de resposta imune se dá de maneira bem diferente da 'via clássica', $\mathrm{T}_{\mathrm{H}} 1$, quer seja iniciada por basófilos, DCs FceRI ${ }^{+}$, NHC, nuócitos ou $\mathrm{MPP}^{\mathrm{type} 2}$. E isso tudo não deve servir de desistímulo. Ao contrário, muitas respostas diferentes para a mesma questão significa interesse nesta e não necessariamente há uma única verdade. No fim das contas, esses achados só mostram como o campo ainda é vasto e o sistema imune se utiliza de mecanismos muito mais diversificados do que imaginávamos. O Hajj é necessariamente tortuoso, mas quando se chega à Meca "ergue-se uma ideia, a Caaba, uma ideia clara e visível, revestida de preto- o pano, um véu de noiva; os ornamentos dourados, uma canção de amor" [14].

\section{Referências}

1. Bowker J (1997) Annotated World Religions; London DKL, editor.

2. Kuhn TS (1962) A Estrutura das Revoluções Científicas; Perspectiva, editor.

3. Mosmann TR, Cherwinski H, Bond MW, Giedlin MA, Coffman RL (1986) Two types of murine helper $\mathrm{T}$ cell clone. I. Definition according to profiles of lymphokine activities and secreted proteins. J Immunol 136: 2348-2357.

4. Sokol CL, Barton GM, Farr AG, Medzhitov R (2007) A mechanism for the initiation of allergen-induced $\mathrm{T}$ helper type 2 responses. Nat Immunol.

5. Perrigoue JG, Saenz SA, Siracusa MC, Allenspach EJ, Taylor BC, et al. (2009) MHC class II-dependent basophil-CD4+ $\mathrm{T}$ cell interactions promote $\mathrm{T}(\mathrm{H}) 2$ cytokine-dependent immunity. Nat Immunol 10: 697-705.

6. Yoshimoto T, Yasuda K, Tanaka H, Nakahira M, Imai Y, et al. (2009) Basophils contribute to $\mathrm{T}(\mathrm{H}) 2-\operatorname{IgE}$ responses in vivo via IL-4 production and presentation of peptide-MHC class II complexes to CD4+ $\mathrm{T}$ cells. Nat Immunol 10: 706-712.

7. Sokol CL, Chu NQ, Yu S, Nish SA, Laufer TM, et al. (2009) Basophils function as antigen-presenting cells for an allergen-induced $\mathrm{T}$ helper type 2 response. Nat Immunol 10: 713-720.

8. Hammad H, Plantinga M, Deswarte K, Pouliot P, Willart MA, et al. (2010) Inflammatory dendritic cells--not basophils--are necessary and sufficient for induction of Th2 immunity to inhaled house dust mite allergen. J Exp Med 207: 2097-2111.

9. Moro K, Yamada T, Tanabe M, Takeuchi T, Ikawa T, et al. (2010) Innate production of $\mathrm{T}(\mathrm{H}) 2$ cytokines by adipose tissue-associated c-Kit(+)Sca- 
1(+) lymphoid cells. Nature 463: 540544.

10. Neill DR, Wong SH, Bellosi A, Flynn RJ, Daly M, et al. (2010) Nuocytes represent a new innate effector leukocyte that mediates type-2 immunity. Nature 464: 1367-1370.

11. Saenz SA, Siracusa MC, Perrigoue JG, Spencer SP, Urban JF, Jr., et al. (2010) IL25 elicits a multipotent progenitor cell population that promotes $\mathrm{T}(\mathrm{H}) 2$ cytokine responses. Nature 464: 1362-1366.
12. Zhu J (2010) Transcriptional regulation of Th2 cell differentiation. Immunol Cell Biol 88: 244-249.

13. Islam SA, Chang DS, Colvin RA, Byrne MH, McCully ML, et al. (2011) Mouse CCL8, a CCR8 agonist, promotes atopic dermatitis by recruiting IL-5+ $\mathrm{T}(\mathrm{H}) 2$ cells. Nat Immunol 12: 167-177.

14. Trojanow I (2006) O Colecionador de Mundos; Letras Cd, editor. 